$1-1-1957$

\title{
The nature of competition among apple processors in the Appalachian area
}

Homer C. Evans

Follow this and additional works at: https://researchrepository.wvu.edu/ wv_agricultural_and_forestry_experiment_station_bulletins

\section{Digital Commons Citation}

Evans, Homer C., "The nature of competition among apple processors in the Appalachian area" (1957). West Virginia Agricultural and Forestry Experiment Station Bulletins. 405.

https://researchrepository.wvu.edu/wv_agricultural_and_forestry_experiment_station_bulletins/390 @ WVU. It has been accepted for inclusion in West Virginia Agricultural and Forestry Experiment Station Bulletins by an authorized administrator of The Research Repository @ WVU. For more information, please contact ian.harmon@mail.wvu.edu. 


\section{BULLETIN 405 \\ June 1957}

The Nature of Competition Among Apple Processors in The Appalachian Area

WEST VIRGINIA UNIVERSITY AGRICULTURAL EXPERIMENT STATION 


\section{THE AUTHOR}

Homer C. Evans, author of The Nature of Competition Among Apple Processors in the Appalachian Area, is Associate Agricultural Economist in the West Virginia University Agricultural Experiment Station.

West Virginia University Agricultural Experiment Station

College of Agriculture, Forestry, and Home Economics

H. R. Varney, Director

MoRGaNTOWN 
THE NATURE OF COMPETITION AMONG APPLE PROCESSORS IN THE APPALACHIAN AREA

\author{
HOMER C. EVANS
}




\section{ACKNOWLEDGEMENTS}

The author appreciates the cooperation and assistance of the following individuals in making data available and in reviewing a preliminary draft of the study: Gordon Bowman, Bowman Apple Products Company; M. E. Knouse, The Knouse Foods Cooperative, Incorporated; J. A. Hauser, The C. H. Musselman Company; W. IV. Hunt, National Fruit Products Company and J. P. Arthur, Shenandoah Valley Cider and Vinegar Corporation.

The author wishes to express his appreciation to his colleagues; W. W. Armentrout, James H. Clarke, W. S. Hutson and Roger W. Pease of Vest Virginia University and to W. W. Cochrane and $O$. B. Jesness of the University of Minnesota. Their assistance and critical review have contributed much in the preparation of this manuscript.

Appreciation is expressed to Mrs. Minnetta C. Justice for preparing the charts and to Miss Louise Rich for an excellent job of typing the manuscript in its various stages of development. Errors of fact, judgment or logic are, of course, the responsibility of the author alone. 


\section{Contents}

\section{CHAPTER I}

INTRODUCTION T T

Statemext of the Problem

Major Questioss to be ANalyzed ...___ T

Methods of ANalysis _... n n S

SOURCES OF DATA _ _ n _ n 9

\section{CHAPTER II}

THE IDENTIFICATION AND CLASSIFICATION OF THE PRICE . MAKING UNIT

Identification of the Price Making Unit - 11

The Concept of a Market _____.._ 11

Criteria for Grouping Sellers _...... 11

Criteria for Grouping Buyers

Market Sub-Group

Relationship of a Market Sub-Group to a Market Place 14

Relationship Among Market Sub-Groups _____ 1.4

Classification of Market Sub-Groups 15

Power Relations $\quad 15$

Cross-purchase and Cross-sales Schedules 16

Number of Firms in the Group ___ 16

Product Differentiation 17

The Effect of a Cooperative on Price Beharior _ _ _ is

Ease of Entry

Concluding Remarks on Structure

Power Relation Between Buyer and Seller _

\section{CHAPTER III}

HISTORICAL BACKCROUND OF PRODUCTION ANI) (TTIIIZATION OF APPLES

Prodection a nen

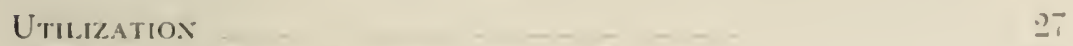

The Production of Apple Slices and Sance

SuMmary 


\section{CHAPTER IV}

DELINEATION OF THE MARKET SUB-GROUPS INVOLVING APPLE PROCESSORS IN THE APPALACHIAN AREA

Apple Sellers

Substitutability

Industry Concept

Sellers of Products Other Than Apples _._. 41

Power Relation Among Apple Sellers _..._ _..._. 42

APPle BuYers $\ldots$

Fresh Buyers $\quad 43$

Substitutability __. 43

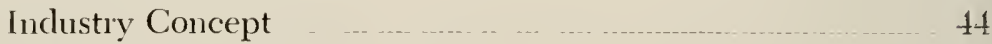

Power Relation Among Fresh Buyers ..._.... 44

Processor Buyers _. 44

Substitutability ___ _ 45

Substitutability Between Fresh and Processor Buyers _.......... 47

Industry Concept _...

Power Relation Among Processors …. _..____... 48

Characteristics of Processors _._._. 48

Summary of Power Relations Among Processors _...... 51

Cooperative _.... 52

Entry of New Firms ______ 52

Summary of Market Sub-Groups Found in the Appalachian AREA

\section{CHAPTER V}

DESCRIPTION OF OPERATING POLICIES AND CONDITIONS CONFRONTING PROCESSORS

Nature of Demand aid Supply Relations for Processors . $\quad 5.5$

Nature of Demand

Nature of Supply $\ldots . .57$

Procurealent Policies of Processors $\quad 59$

Price Policies _... 59

Implicit Price Policies _....... 61

Long Run View _- 62

A Processor's Analysis of the Situation …. 64

Some Characteristics of Kvouse _....... 68 
Nature of Processor Costs _._._. $\quad 69$

ENTRY OF New FirMIS ………_. 74

SUMMARY …………

\section{CHAPTER VI}

ANALYSIS OF CONPETITIVE BEHAVIOR ANONG APPLE PROCESSORS, IN THE APPALACHIAN AREA TI

Ax Axalysis of Factors Affecting Competition

Duopsony, One Firm Being a Cooperative is

Effect of Implicit Price Deals on Competition __ 79

Effect of Entry on Competition

How Large Firms . Yay Combat Competition _____ S?

Entry of an Integrated Grower-Processor $\quad S 4$

SUMMARY ……............ S4

\section{CHAPTER VII}

IMPLICATIONS AND CONCLUSIONS ST

APPENDIX I. SUPPLEMENTARY TABLES _-

APPENDIX II. SUPPLEMENTARY MATERIAL 97

SELECTED BIBLIOCRAPHY 99 
Digitized by the Internet Archive in 2010 with funding from

Lyrasis Members and Sloan Foundation

http://www.archive.org/details/natureofcompetit405evan 


\title{
Chapter I
}

\section{INTRODUCTION}

\section{Statement of the Problem}

\begin{abstract}
$\triangle$ PPLE processors are an important outlet for apples in the Appalachian Area. ${ }^{1}$ In recent years this outlet has been taking approximately one-half the crop. A relatively few processors buy apples in the area.
\end{abstract}

In 1952 the Federal Trade Commission (FTC) charged the principal apple processing firms in the Appalachian Area and a grower organization with: "(1) fixing, establishing and maintaining prices to be paid for apples for processing purposes; (2) fixing and establishing a mathematical percentage pricing formula for calculating the prices to be paicl for various grades of apples and price differentials between such grades, and (3) diverting raw apples from one processor to another for the purpose of maintaining the prices thereof set by respondents, all in violation of the Federal Trade Commission Act."ing examiner Hier dismissed the charges. This decision has been upheld through subsecquent appeals.

There has been a growing concern as to how the price of apples for processing is established. At the present time growers are attempting to organize in order to bargain with processors on price. There appears to be some question as to the amomt of competition among processors in the Appalachian Area.

\section{Major Questions to be Analyzed}

The objective of this study is to determine the nature and the amount of competition among apple processors in the Appalachian treal. The effects of competition are registered through price. Price is the focal point of our allocating mechanism; that is, it directs production and comsumption and distributes incomes. Therefore the "perfectuess" with which price performs its allocating functions is of interest to all. Is there strong

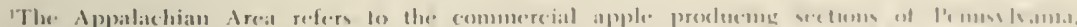

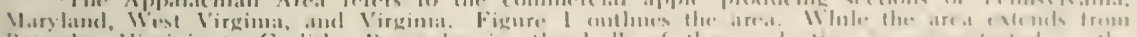

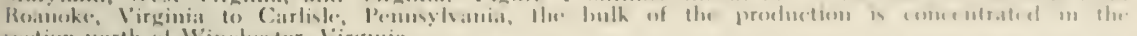
section lesth ol Wincheserer. Vircumias.

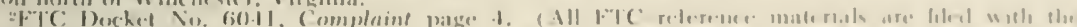

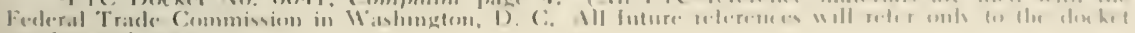
rumber anel pitge'.) 


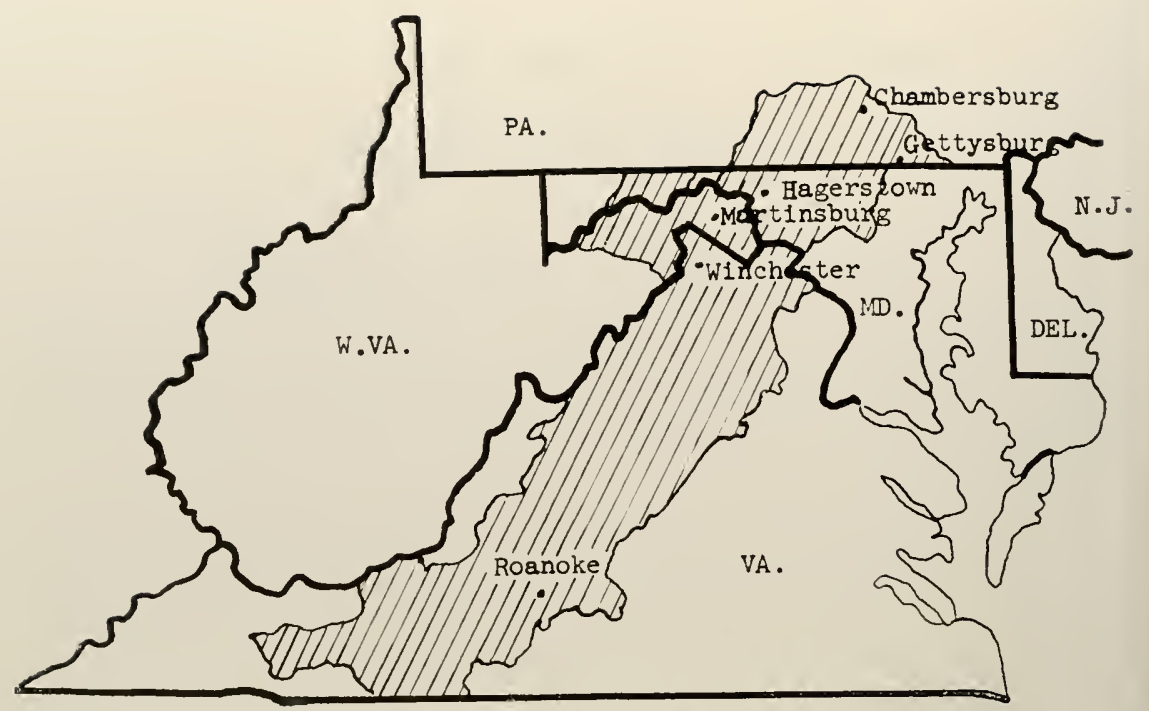

FIGURE 1. Appalachian Area (outline of commercial apple-producing sections of Pennsylvania, Maryland, West Virginia, and Virginia).

competitive pressure resulting in a price approaching the optimum, relative to the allocation and returns to resources? Or is there lack of competitive pressure among firms, resulting in inefficient use of resources? Are the marginal productivity and returns for comparable resources the same in all alternative uses? What factors tend to restrict competition? Also, what are the factors responsible for competition? How do these confilicting forces offset the effect of each other?

\section{Method of Analysis}

The analysis of this problem is approached by setting up in Chapter II certain criteria for identifying the firms included in the groups in which price is established. The price-making unit or market sub-group is classified in rather general groupings. This classification is on the basis of certain factors that affect the competitive pressure in a market sub-group, namely, power relation, ease of entry of new firms and whether a cooperative firm is present. The effect of these factors on competitive behavior is discussed.

In Chapter III an analysis is made of the national production and utilization of apples, with emphasis on the Appalachian Area's role in the nation's picture. This chapter gives the historical background necessary for the delineation of the market sub-groups involving the Appala- 
chian Area. Therefore, Chapter IV is devoted to an actual delineation of the market sub-groups in the area and to the identification and description of the processor firms.

Chapter $\mathrm{V}$ is devoted to a description of operating policies and of the conditions confronting processors. In other words, it describes the behavior of processors. Chapter VI interprets processors' behavior in tems of competitive pressure.

Chapter VII presents a summary of the study and the conclusions which were drawn from the analysis.

\section{Sources of Data}

Data relative to production, utilization, and price of apples were obtained from reports of the Crop Reporting Board, Agricultural Ilarketing Service (A.MS), United States Department of Agriculture (USDA). The study is confined to the period since 1934 and to commercial areas only: This was done because of the difficulty of obtaining data prior to $19: 34$ and because most of the important developments among processors in the Appalachian Area have occurred since then. In 19:3t the USI).1 Crop Reporting Board limited its estimates to commercial areas in 3.5 states. Consequently, data prior to 1934 are not comparable to those since 19:34. In 1950 only 1 per cent of total national apple production was produced in the other 13 states. Prior to $19: 36$ very little datal were available relative to individual processors. Also, most of the changes which are of interest to this study have occurred since 1934

In a study concerned with the nature of competition among a few firms it is essential to have clata relative to the operations and behavior of individual firms. These data often are either not available or rather limited. However, in this study considerable data pertaninger to indisidual precessing firms and also statements as to their competitive behanior were obtained from the records of the Office of Price Administration (OP. I), from the Office of Price Stubilization (OPS), from P'TC, and from the individual processors. Although the data are not available for all years and often are limited as to cletails, it is folt that the? are aderpiate for purposes of this study.

Data pertaining to the production of sinee and sliees were ohtaned Irom the National Canners Issociation. (Natienal Cammers Lesecioltion

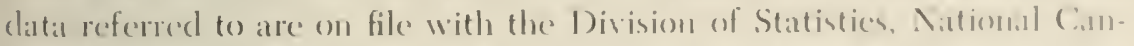
uners Association, Washington, D). C. Future references will reder mols te National (ammers . Association diatir.) 



\section{Chapter II}

\section{IDENTIFICATION AND CLASSIFICA- TION OF THE PRICE-MAKING UNIT}

7 HE purpose of this study is to determine the nature of competition among apple processors in determining price. In order to answer

1 this question the market and its structure must be defined rather closely.

\section{Identification of the Price-Making Unit}

\section{THE CONCEPT OF A MARKET}

Marshall defined a "perfect market" as follows:" “. . . a clistrict, small or large, in which there are many buyers and many sellers all so keenly on the alert and so well acquainted with one another's affairs that the price of a commodity is always practically the same for the whole of the district." The Encyclopedia of the Social Sciences defines a market as follows: ". . . the area within which the forces of supply and demand converge to establish a single price." Waite and Trelogan say that at market is" "A sphere within which price-making forces operate andi transfers of ownership are consummated." Papandreou and Wheeler consider a market to be:" ". . . the forces which molerly some set of purchase and sale transactions, namely the forces of supply and demand."

There is a need to go further than this general and abstract concept of a market in delimiting the firms to include in an empirical study: Such a study deals with social forces and therefore it is difficult to identif! the boundaries of a particular market and set it apart from other markets.

\section{CRITERIA FOR GROUPING SELLERS}

Papandreou and Wheeler suggest that the boundaries of a particulan market may be deliniated by the identification of the eroup of loneres and sellers affected by common forces of supply and demand.; The 1). 112

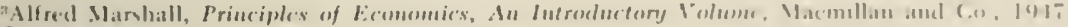

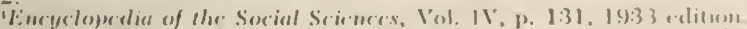

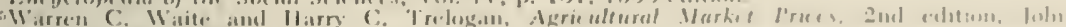
Wiley and soms. Inc., 1948, 1). 128

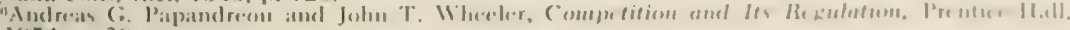
1 Ius., 1954 , p. 20.

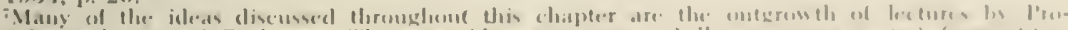

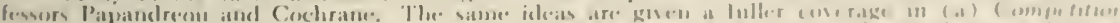

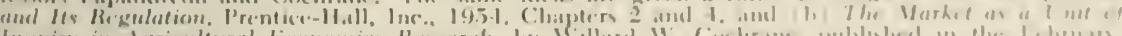

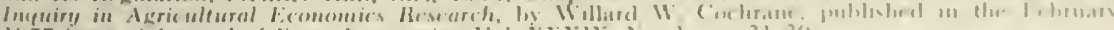

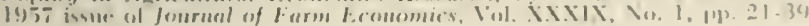


identification of sellers affected by common forces of supply and demand may be accomplished through the use of a cross-demand schedule. By cross-demand schedule, or curve, is meant the relation between the quantity demanded of the product of one firm and the price quoted on the product of some other firm, on the assumption that tastes, incomes, and other prices are given. The shape of the cross-demand schedule of two firms indicates the character of the relation between the demands for their products.

The nature of the cross-demand curve may be summarized as follows: If the cross-demand curve relating two products is constant (a horizontal line) the two products are independent, and the firms concerned with the two products are not subject to common market forces. If the cross-demand curve is not horizontal, then the two firms are subject to common market forces. If the cross-demand schedule is generally increasing from left to right, the two products are substitutes for one another; and if it is generally decreasing from left to right, the two products are complementary to one another.

Papandreou and Wheeler suggest that in describing the schedules the word generally precede either increasing or decreasing to indicate that its general shape suggests an increase or a decrease." It is possible that some of the points of the schedule may lie on a horizontal line. This, however, is consistent with a generally increasing or decreasing schedule. The more nearly two products are substitutable for each other, the steeper will be the cross-demand curve and the more the firms concerned with the two products will be subject to common forces of supply and demand. Also, the less two products are substitutable for each other, the less sloping the cross-demand curve will be, and the less the firms concerned with the two products will be subject to common forces of supply and demand.

If two firms sell either complementary or substitute products, they are subject to common forces of supply and demand. However, the nature of the relationship of the two firms is quite different in the two cases. If the two firms sell substitute products, the nature of the crossdemand curve is essentially a competitive one. On the other hand, if the two firms sell complementary products, the nature of the crossdemand curve is essentially a cooperative one. Since this study is concerned with the nature and extent of competition among apple processors in the Appalachian Area, the analysis will be concerned with whether or not the firms find themselves-through the market-in a competitive 
relationship with respect to each other. Therefore, the criterion for grouping firms together will be whether or not they are selling or buying substitute products.

Using the cross-demand schedule as a criterion for grouping firms. it is easy to see that some price of one product can be found which will affect the demand for many other normally unrelated products. These extremely high or low prices may be considered unrealistic or likely never to occur. Therefore the gromping of firms will be restricted to the meaningful part of the cross-demand schedule in order to avoid grouping together firms which never really find themselves in a competitive relationship.

\section{CRITERIA FOR GROUPING BUYERS}

The criteria for grouping buyers together are quite similar to those used for grouping sellers. To the buyers the concept of cross-supply schedule is analogous to that of cross-demand schedules for the sellers. If two buyers are substitute outlets, their cross-supply schedule will he generally decreasing or downward-sloping. Therefore, all firms with a generally downward-sloping cross-supply schedule will be in the same market groups.

\section{MARKET SUB-GROUPS}

So far the concept of a market has been limited only by whether the products of any two firms are substitutes. It is desirable to limit the scope of the market to prices which may be meaningful in the seme that they are likely to occur within some prescribed range. It was pointed out that the matter of substitution is not a matter of being perfectly substitutable or of being perfectly independent but generally a matter of imperfect substitutability and the extent of substitution is indicated hy the general shape of the cross-elemand schedule. This still leawe at rather heterogeneous group of firms in the same matket. For evalmple. alpple processors in the Appalachian Area and fresh market apple brisers in the same area are cortainly buying substitute products and offerine substitute outlets for the same products. Howerer, the lwo eremps ot buyers inay be confrouted with guite different problems.

To analyze price behavior it maty he useful to natrow the ared under

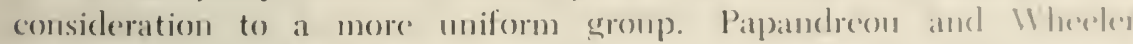
sugerest that this be clone ly the concept of an inclustry. Bs inchustr? they mean that the firms in question display a similar structumal fatferm

"Ihisl., Chiolpler 4 
The phrase, similar structural pattern, indicates that the firms have similar technological, market, and organization problems. In other words. all pertinent conditions confronting the firms in the same industry are similar. Industry grouping usually falls along product lines. The concept of an industry provides the criteria for narrowing the market to an analytically meaningful size. The market sub-group consists of all the firms that belong to the same market group and at the same time belong to the same inclustry. It includes all the firms that sell substitute products and have similar structural patterns. The market sub-group becomes a common unit of inquiry. The firms are relatively homogeneous, confronted by similar problems and in relatively close competitive relationships. It is within this mit that sellers actively compete with one another, buyers and sellers actively bargain with one another, and price is formed.

\section{RELATIONSHIP OF A MARKET SUB-GROUP TO A MARKET PLACE}

A market sub-group has been defined as comprising all the firms selling substitute products and at the same time having similar structural patterns or belonging to the same industry. A market place may be defined as comprising the area in which ownership of the product changes hands. The market sub-group may be made up of many or few market places, depending upon the particular sub-group under consideration. For example, there may be hundreds of market places where fresh apples change hands, but the United States may make up only one market sub-group. The market places are the areas of operation of the market sub-group. They are linked together by high degree of substitution of sellers between market places. Any one market place may or may not play an important part in establishing price. but market places taken together make up the market sub-group.

It is not necessary that supplies move between two market places for both market places to be in the same market sub-group. However, the important thing is that if price between the two market places varies more than cost of transportation, supplies will shift from one to the other.

\section{RELATIONSHIP AMONG MARKET SUB-GROUPS}

Market sub-groups are linked together by a network of substitution among the sub-groups. The degree of substitution between two subgroups affects the elasticity of the supply or demand curves of the subgroups. Assuming that fresh apple buyers make up one market subgroup and processor buyers another, and that sellers are indifferent as 
to which sub-group they sell, there will be a high degree of substitution by sellers between the two sub-groups. This will affect the shape of the supply curve of the two sub-groups. On the other hand, assuming that the processors in the Appalachian Area make up the buyers of one subgroup and the processors on the west coast another, and assuming that transportation costs relative to processor prices prohibit sellers from substituting one market sub-group for another, the supply curves of the two sub-groups will be independent of each other. Also. institutional barriers may limit the substitution between market sub-groups or even limit the firms included in a sub-group. For example, quotas and tariffs restrict the movement of apples between the United States and Canada. In summary, the degree of substitution between market subgroups determines the nature of the demand and supply curves for the sub-groups.

\section{Classification of Market Sub-Groups}

Classification of market sub-groups may be macle on the basis of the structure of the group. By structure is meant those factors which have a significant influence on the conduct or behavior of the decision makers in establishing prices.

Two structural elements immediately come to mind when we consider market classification, (1) the number in the market, and (2) prochuct differentiation (or its lack, product homogeneousness). These two elements determine the power relations among firms in a market sub-group. They determine the ability of one firm to infuence the behavior of other firms in the market sub-groups.

\section{POWER RELATIONS}

If the products of two firms are homogeneous, al cut in priec by one will lead to a reduction in sales of the other. For this to take place, two conditions must be present: (1) the buyers must be willing and able te) buy one or more units of the product at the quoted price, and (2) the sellers must be willing and able to place these mits on sale at the puoted price. This immediately raises the question of the ability of a firm to follow an independent pricing policy. In other words, cinn one firm force other firms to follow, or does it produce such a small part of the totial supply of the product that it is mable to mathe at price chamee effective. 


\section{CROSS PURCHASE AND CROSS-SALES SCHEDULES}

It was found helpful to consider only the meaningful part of the cross-demand or cross-supply curves. For any given firm, it also seems necessary to consider only the meaningful part, or that part of the crossdemand or cross-supply curves over which it can make a price change effective by its ability to buy or sell a sufficient quantity of its product to satisfy the demand at the quoted price. Papandreou and Wheeler suggest the use of the term cross-purchase and cross-sales schedules. ${ }^{10}$ The cross-purchase or cross-sales schedules differ from the cross-demand or cross-supply schedules in that the former depicts the nature of substitution of two products over all conceivable alternative prices and quantities, whereas the latter refers only to the prices and quantities which a firm has the capacity and resources to make effective. The cross-purchase and cross-sales schedules become important when considering the power relationship among firms. For example, under conditions of perfect competition, any firm is unable to affect the sales of any other firm measurably because of its inability to supply the market sub-group at lower price. On the other hand, under conditions of oligopoly, a firm may be able to affect the sales of other firms due to its ability to supply the market sub-group at a lower price.

\section{NUMBER OF FIRMS IN THE GROUP}

The significance of the number of firms in a market sub-group is registered by whether a firm can affect the sales of other firms by changing its own price. Therefore, the absolute number of firms is not the important thing but rather the power relations or ability of one firm to affect the behavior of others. A firm may find itself in one of four power relations in a market sub-group, (1) atomistic, (2) circular, (3) dominant, or (4) unique ( single seller).

The relationship is atomistic if any firm lacks power to affect measurably, through a change in price, any other firm in the market sub-group. This would involve a relatively large number of firms and each firm may be decsribed as a price taker in that it is impotent in effecting a price change by itself.

The relationship is circular if any firm has the power to affect the sales of any other firm in the market sub-group by a change in price. There are relatively few firms in a circular group. In this group a firm may be described as a price maker in that it has the power to change price and make it effective. The degree of the effect of price change of

"Ibid., pp. 38-44. 
any one firm on the sales of any other firm in the market sub-group may vary from only slight to complete, namely, taking all the customers from the other firms. The extent of the effect is determined by whether or not the products of the firm are homogeneous or differentiated. This will be discussed later.

The relationsluip is one of dominance if one firm can affect the sales of another firm by cutting price but the second firm cannot affect the sales of the first firm by cutting price. One firm has power with respect to the other, but the second is completely impotent with respect to the first. Dominance is the combination of a circular and atomistic relationship. A few dominant circular firms with several atomistic snall competitive firms give probably the most important power relation that will be found among processors of agricultural products.

The unique firm or single seller is the only firm in a sub-group. Therefore, it will be a price maker, and competitive pressure will have to come from some firm in another sul-group. A monopolist will represent an isolated seller.

The number of firms in a sub-group largely determines whether the power relation among a group of firms is atomistic, circular or single seller. However, the clegree of product clifferentiation plays an important part in the competitive behavior of the firms in a group, particularly in a circular sub-group where there is some freedom of choice as to behavior on the part of the individual firms.

\section{PRODUCT DIFFERENTIATION}

Product differentiation has reference to the degree of substitution. If the product is homogeneous the substitution is perfect. IIowerer, if there is differentiation, substitution is less than perfect, the deerere depending upon the extent of differentiation.

Whether or not the product is differentiated has an influence an price behavior. Under a circular or oligopoly situation, with a lomencenems product, there is perfect oligopoly or exeryone must sell at the same price; but with a differentiated product there is imperfect oligepuly, as "veryone doess not have to sell at the same price." fut the case at perfect oligopoly, if one firm cuts its price, all othere firms must immediaterly follow or they will lose all their sales to the firm which ent price: this is alssuming that the firm could supply their prochet in sullicient efuntitices. In the case of imperfect oliegopoly there is clifferentiation of the predeled."

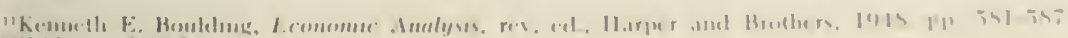

llid., 1). Jiss-รせl. 
Therefore, a price cut by one firm will not immediately attract all of the customers of the other firms. Retaliation is slow, or may not occur, depending on the degree of product differentiation. In Chamberlin's large numbers case, product differentiation is the essential element for monopolistic competition; otherwise the case would be pure competition. $^{13}$ In the case of large numbers the firm is faced with a perfectly elastic demand curve if the product is homogeneous (pure competition); whereas with a differentiated product there is some slope to the demand curve, depending upon the degree of differentiation (monopolistic competition ).

The degree of substitution is the criterion used to distinguish or to classify together units of goods as homogeneous or differentiated. Therefore, the same product, at different places may be called different products. The cost and inconvenience of transporting the product from one place to another determine the degree to which the product is differentiated due to location. If the cost of transporting is higher relative to price, the degree of differentiation is also high, whereas if the cost is low relative to price, the degree of differentiation is low.

Closely related is the matter of substitution of a product through time. If a product can be easily stored (stored relatively cheaply), it affects the nature of the supply curve of the product. Also, it may increase the capacity of a firm, and this would tend to increase the degree of circularity. For a given level of substitution, the greater the excess capacity of a firm in a sub-group, the greater the circularity.

\section{THE EFFECT OF A COOPERATIVE ON PRICE BEHAVIOR}

Historically, cooperatives are pictured as a means whereby users increase their returns or decrease cost, provided present alternatives are inefficient or "excess profits" are made by present firms performing the service. "Normal profits" are considered as part of total cost and necessary if a firm is to stay in business. "Excess profit" is the difference between total profits and "normal profits." In a circular sub-group excess profits are expected. How does a cooperative as a member of a circular sub-group affect the price behavior and profits of the group?

An illustration serves to show how a cooperative brings competitive pressure on other members of a sub-group. Assume that the buyers in a market sub-group of apple processors are made up of two firms identical in every respect except that firm A is a cooperative and firm B is an ordi-

Edward Hastings Chamberlin, The Theory of Monopolistic Competition, A Re-orientation of the Theory of Value, 5th ed., Cambridge, Harvard University Press, 1947, pp. 90-94. 
nary corporation. Since the two firms are identical, except that one is a cooperative, their costs of processing and distributing processed products will be identical. To simplify the illustration it is assumed that the cost of processing and distributing their products is constant at all outputs, except for the cost of apples for processing.

AGR in Figure 2 represents average gross revenue or demand for processed apple products for the sub-group which is composed of two firms. Since the cost of processing and distributing is identical and constant at all outputs for both firms, the derived average revenue or demand for apples of the sub-group lies below AGR by a constant amount. In Figure 2 DDAR represents the derived demand curve for apples for the sub-group. The area between AGR and DDAR represents the cost of processing and distributing for the sub-group. ${ }^{1+}$

Since each firm has one-half the total derived demand, D.M is the demand curve for apples for each of the firms, as it is one-half of DDAR. D.M is also the average revenue curve for each of the firms, and DR is marginal revenue. It is assumed that SS is the supply curve of apples for

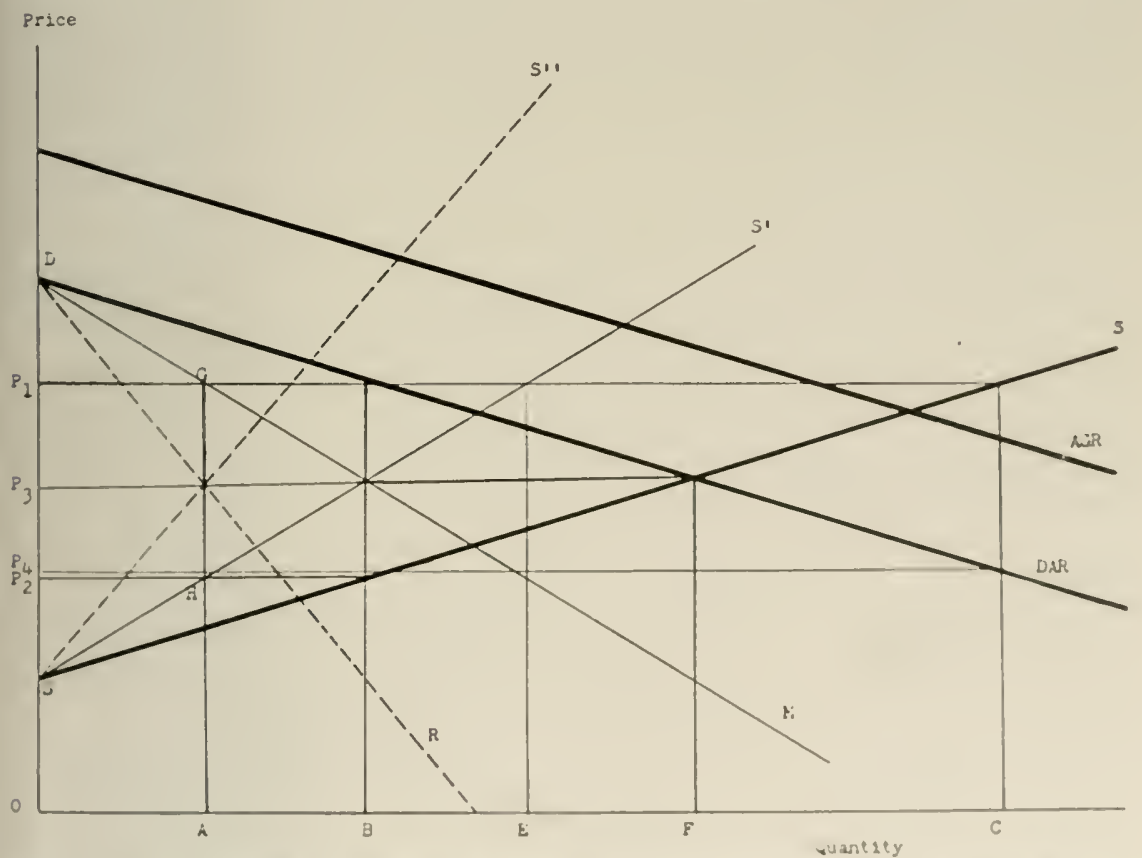

FIGURE 2. Hypothetical market sub-group situation involving o cooperotive.

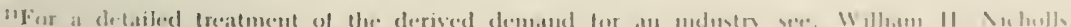

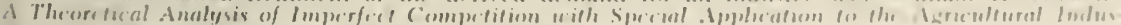

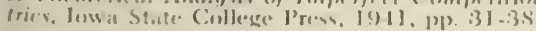


the two firms. SS' is the supply curve each firm faces, as it is one-half of SS. SS also is the average cost eurve of apples for each firm. Assume that firm B sets a price to be paid for apples. Firm B would set a price at $P_{2}$, taking quantity $O A$ and selling at price $P_{1}$, giving a net profit of $\mathrm{P}_{1} \mathrm{GHP}_{2}$, which is at a maximum. This is also the maximum for firm $A$.

However, unlike firm $B$, firm A pays price $P_{1}$ to its members, returning all profits in patronage dividends. Since growers are indifferent as to which firm they sell, they will be unwilling to sell to firm $\mathrm{B}$ at $\mathrm{P}_{2}$ when firm $A$ is paying $P_{1}$. Consequently, to meet the competition from $A$, firm $B$ will be forced to raise its price.

This situation leaves the apple sellers dissatisfied. At a price of $\mathrm{P}_{1}$ they are willing to sell a total quantity of $\mathrm{OC}$, or $\mathrm{OE}$ amount to each firm. However, the processor derived demand will take only $\mathrm{OB}$ quantity at price $P_{1}$. With $O C$ quantity the sub-group can only get price $P_{4}$. This is less than they paid for apples, therefore, processors will reduce the price paid for apples. As processors reduce their price for apples, growers are willing to sell fewer apples and processors can sell a larger quantity of apple products without incurring a loss. This process will continue though successive price reductions for apples until price reaches $\mathrm{P}_{3}$.

At price $\mathrm{P}_{3}$ growers are willing to sell quantity $\mathrm{OF}$, and the processors are able to sell that quantity. The processors are making normal profits, or sufficient to stay in business. They are not making excess profits as previously. However, if they take a quantity less than OF, and firm $A$ continues to return all over cost of operation to growers, the price will be forced back to $\mathrm{P}_{3}$, each firm taking quantity $\mathrm{OB}$. Therefore, if we assume that all firms are identical, that growers are indifferent to which processor they sell, and that the cooperative returns all over cost to the apple sellers, profits will be reduced to normal or that amount necessary to keep the processors in business. Average costs will equal average revenues as under perfect competition, provided production costs per unit are the same under imperfect and perfect competition.

The illustration on the effects of a cooperative assumes that there is nothing to dampen the effect of the price paid by the cooperative, and that the operation of the cooperative is quite responsive to the demands of its patron members. These two assumptions need closer examination. Although a cooperative is organized on a somewhat different basis from that of an ordinary corporation relative to the distribution of "net 
returns," control, returns on capital, and ownership of stock, it is quite possible that in practice the two may have similar operating practices. However, the important point is that the cooperative has forced some of its practices on the other firms, namely that of returning excess profits to apple growers. ${ }^{15}$

Is there anything in the operational procedures of a cooperative to clampen the full effect of the price which it pays? The answer is yes. Generally the full price to be received is not known until after the apple grower has decided what part of his crop he will sell to the processor. Also, cooperatives often return only part of the full price in cash. All this tends to dampen the full effect of the cooperative. However, if a cooperative performs as assumed in Figure 2 such action will set a pattern as to the expectations of members, which will tend to offset the dampening effect.

\section{EASE OF ENTRY}

The ease of entry of new firms in a sub-group is certainly a factor affecting the behavior of the firms in a sub-group. (The ease of entry and threat of potential new firms may have a moderating effect on firms already in a sub-group.) Existing firms may fear that the presence of high excess profits will attract new firms to the sub-group. Therefore, ease of entry is a structural factor to be considered. Ease of entry is closely related to the number of firms and has a clirect influchece on numbers.

Papandreou and Wheeler say that entrance is free if $-11 ;$. "A firm can become a member of a group on terms which are at least as favorable an those which are available to the firms which make up the group in yuestion." The important thing about freedom of entrance is the absence of at differential advantage for the firms already in a gromp).

The optimum size of the firm is an inportant consideration relative to case of entry. It is harder for a firm to chter a sub-(rrenp) if the optimum size of firm is large than if it is small. It may also be easier to (n)ter at sub-group in which demand is expanding than it would to enter me

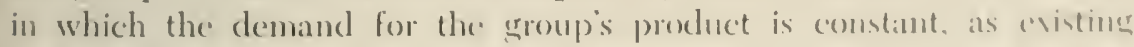
firms would suffer less reduction in output.

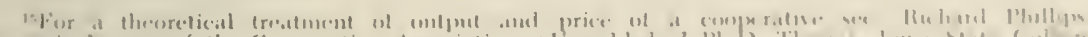

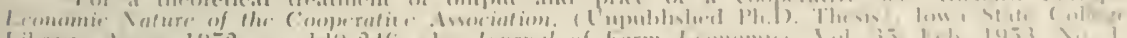

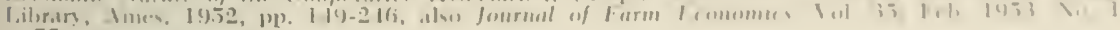
1. $\div 5$. 
Entry of new firms may change the power relation of a group of firms, possibly causing a circular group to become atomistic. In general, it is concluded that the greater the ease of entry, the stronger is competitive pressure.

\section{CONCLUDING REMARKS ON STRUCTURE}

This is not intended to be an exhaustive coverage of structural factors that infuence behavior of firms in a market sub-group; it is intended to point up, from market structure theory, points important to this study. Certainly the power relationship among firms is important. The number of firms in the group seems to be the key factor in determining power relations. The effect of numbers may be modified by the degree of substitution. Substitution includes the degree of differentiation between the products of any two firms in a group. Also, it includes substitution through time and space. The presence of a cooperative modifies the behavior of a group. The entry of new firms also tends to bring competitive pressure in a group. In fact, it may even change the classification of the power relation. There may be many other factors. For example, the relative costs among firms may affect their behavior. Certain factors may affect a circular group and not an atomistic group, clue to the lack of freedom in the latter. For example, processors in the Appalachian Area are concemed about the future supply of apples for processing. Therefore, a processor in a circular or dominant group who is looking forward to a relatively long period of operation may be in a position to take some action toward insuring a future supply of apples, whereas a fresh buyer in an atomistic group could not do so. Some of these aspects, as well as others, will be explored further as to their effect on competitive pressure in the case under study.

In perfect competition, or where the relationships are atomistic once the demand and supply curves for the market sub-group have been defined, price and output may be predicted. This is not true with monopolistic groups where the relationship is circular.

Some of the factors which affect price behavior have been discussed. The effect of factors considered may be viewed in terms of probability. The probability is greater that the firms will behave as indicated, but due to the altematives open to them, they may follow some other pattem. The effect of two factors present may be in confict. and thus the influence of one will be weighed against the influence of the other. Two quotations from Nicholls emphasize the importance of caution in using empirical data to test theoretical models developed on an abstract plane. 
Quoting from Nicholls:" " All market situations must be alpproached on their own merits. Preconceived notions of . . oligopoly situations are just as likely to throw one off the track as to yield light. ire are in the realm of things where individual decision plays an enomously important role. The capricious ... and irrational or mistaken judgment of one member of a market may be far more important than all the theoretical generalizations there are." "Who would deny that price policies would not have been differ-

"7 Dr. J. K. Galbraith, in a letler to the author. For the spicy and printerl iscw

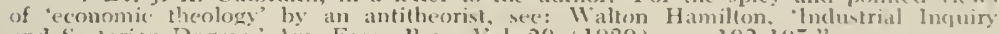
and Sectarian Dogma, Am. Ecom. Re., Vol. 29 (1939), pp. 102-105."

ent in an automobile inclustry without its Ford or a tire industry without its Firestone?

"s Soe Lloyd G. Reynolds, Compelition in the Rubber-Tire Jnduntry, Am. Ecom, Rev., Vol. 28 (1938), pp. 467-6s."

"We must, therefore, realize that our analysis of oligopoly-oligopsony has of necessity proceeded on a very abstract plane. It has presented a serics of models which should be very helpful in empirical work. But this is true only if we are careful to avoid the common failing of empirical studies in econonics whereby "the existing theoretical analysis of an assumed set of circumstances is simply applied to a more complex set of facts and ollered as a complete explanation of the outcome."

“9 Prof. Donald II. Wallace of Williams College, a competene authorily in His field, in il ketter to the athor."

"In the study of any given industry, the assumptions by which dominamt firms climinate or fail to climinate the influence of circular interdependence must be "aurefully chosen on the basis of empirical, factual investigations" ${ }^{10}$."

"I0 Triffin, 1. 78."14

\section{POWER RELATION BETWEEN BUYER AND SELLER}

A market sub-group has been defined as the mit of incpuiry. Each market sub-group is composed of a group of buyers and a group of sellers. So far this study has been concened with the relations amone groups composed of either sellers or buyers. Power relations also exist between buyer and seller groups. If neither buyer nor seller wiclds any power over the other, their relationship is atomistic. If they each wicld power over the other the relation is circular. If either the buyer or the sellere wields power, but the other does not, the relation is one of dominance. It is only when the relations between buyers and sellers are circular that bargaining can take place. When the relations are circular, both gromps wield power and are in a position to bargain.

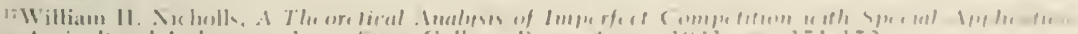

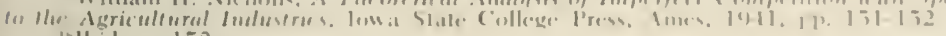

in 1 bid., 1). 152 . 



\section{Chapter III}

\section{HISTORICAL BACKGROUND OF PRODUCTION AND UTILIZATION OF APPLES}

I Chapter II an attempt was made to set up certain theoretical concepts for iclentifying the price-making unit to which a particular firm or group of firms belongs. Also, some ideas were advanced regarcling the structural factors which would effect the competitive behavior of the firms in a market sub-group. These procedural or methodological concepts serve as a guide to the researcher in setting the stage for the analysis of a problem such as is being undertaken in this study.

The buyers and sellers of apples in the market sub-group invols ing the apple processors in the Appalachian Area must be iclentified and their competitive behavior analyzed, in order to evaluate the nature of competition among apple processors in the Area.

As a point of departure, a brief historical account of the production and utilization of apples is presented, with particular emphasis on the Appalachian Area. This arcount will give some idea of the emiromment in which apple sellers and buyers in the Appalachian Area operate.

\section{Preduction}

Production of apples has been reported in every state, but commercial production is limited to about 3.5 states. According to the 19.50 Census of Agriculture, mly 1 per cent of the total national appl. precheretion was in the 133 states where commerecial production was not wperted. In 19:34, the United States Department of Agriculture's Crop iepunting Services began rene.ting production and utilization of apples for commercial areas, and since 19:35 has confined its estimates only to commer $\mathrm{T}$ cial areas in the 35 states. Consecpuently, observations will be confined to the period of 1934 to 1954 .

Figne 3 shows the distribution of apple trees in the Unitred Stoten in 19.50. The butk of the commerevial production is concentrated in at fex areas. Washington state is the mest important, accountine for alount one-fourth of the commercial crop in recent years. The Ippoldedian Area is second, producing approsinately one-fifth of the erop). Nan lork 


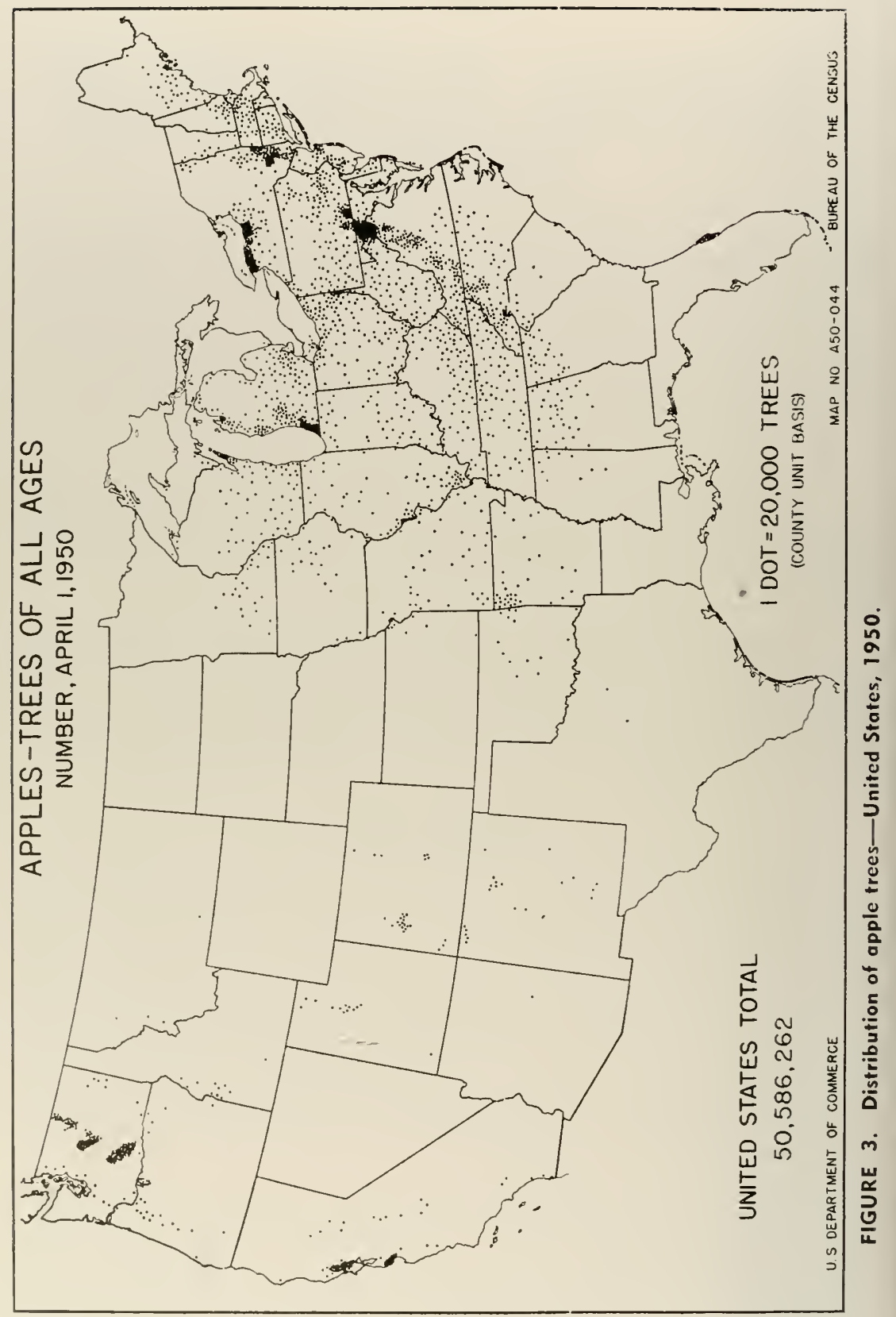


state is in third place, accounting for slightly less than the Appalachian Area. Michigan and California produce smaller, but important. (yuantities. The remainder, about one-fourth of the crop, is scattered over several states, mostly east of the Mississippi River. In summary, about two-thirds of the national crop comes from an area extencling out trom the $A_{\mathrm{P}}$ palachian Area for a distance of about 500 miles, mostly to the north and west, Figure 3 .

Average annual commercial production in the United States from 1934 to 1954 was $112,560,000$ bushels, Figure 4. During the sane period there was an average anmual decrease of 1,126,000 bushels. Figure 4.

Production in the Appalachian Area has followed the same trend as that of the United States. It has tended to decline over the period 19:3t to 1954 , with an average annual decrease of 511,000 bushels. Figure 5.

\section{Utilization}

Although total national production has been declining. sales to the processors have been increasing. The average annual sales to the processors, from $19: 34$ to 1954 , were $28,760,000$ bushels, or about 25 per cent of the crop, Figure 4. During the same period an annual average increase of 230,000 bushels was going to the processors, Figure 4.

The Appalachian Area also has exijerienced an increase in its marketings to processors. The average ammal sales to processors in this area were $8,572,000$ bushels, or about 37 per cent of the area s crop): and during the same period there was an annual average increase of $1,36,000)$ bushels going to processors. Figure 5 . In recent years approximately onehalf of the crop in the Appalachian Area has been sold te processors.

Variety and price are important factors in determining the utilization of the apple crop. The effect of price on utilization will be consiclered in some detail in Chapter $V$; the effect of variety will be given bried consideration at this point.

Although there appears to be a rather high degree of substitution among varieties of apples, sonc varieties are better suited for some use's than others. Red Delicious, McLntosh, and Winesap are gencrally preferred for fresh use, and Gravenstein, Creening, York, and Baldwin are preferred for processing. Stayman, Rome Beauty, Coldend Delicions, and Grimes Golden are considered desirable by eithere the fresh or processing

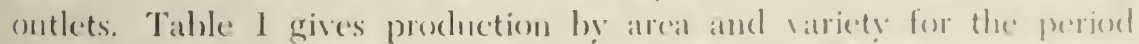
19-42-49. Altheush there is a rather wide distribution of each vartedy, the Appalachian Area and New York state produce at lish proportion of the processing and dual-purpose varieties. 


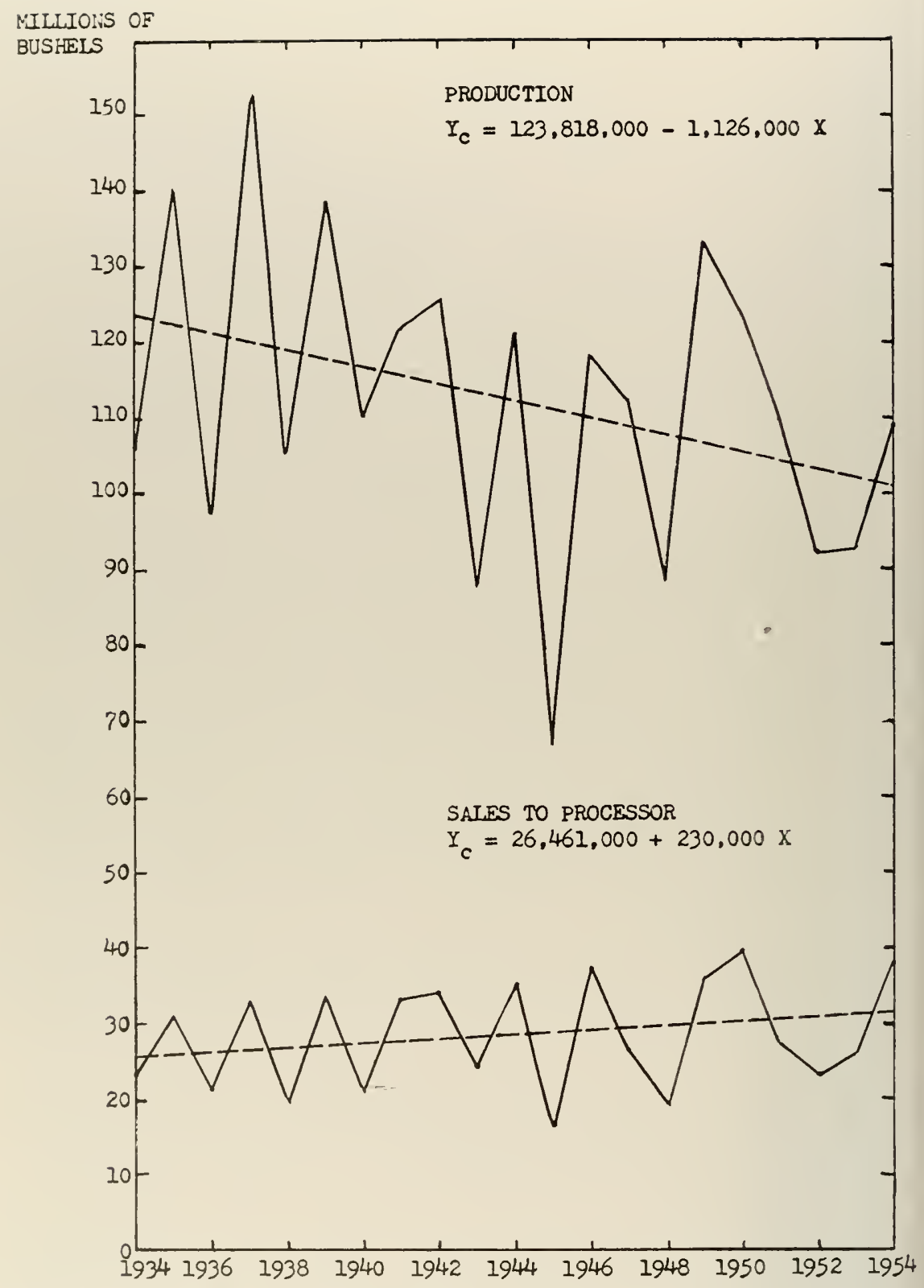

FIGURE 4. Apples-production and trend in production of commercial crop; sales to the processor and trend in soles, United States, 1934-54. (Source: United States Department of Agriculture, Crop Reporting Boord.) 
MILLIONS OF

BUSHELS

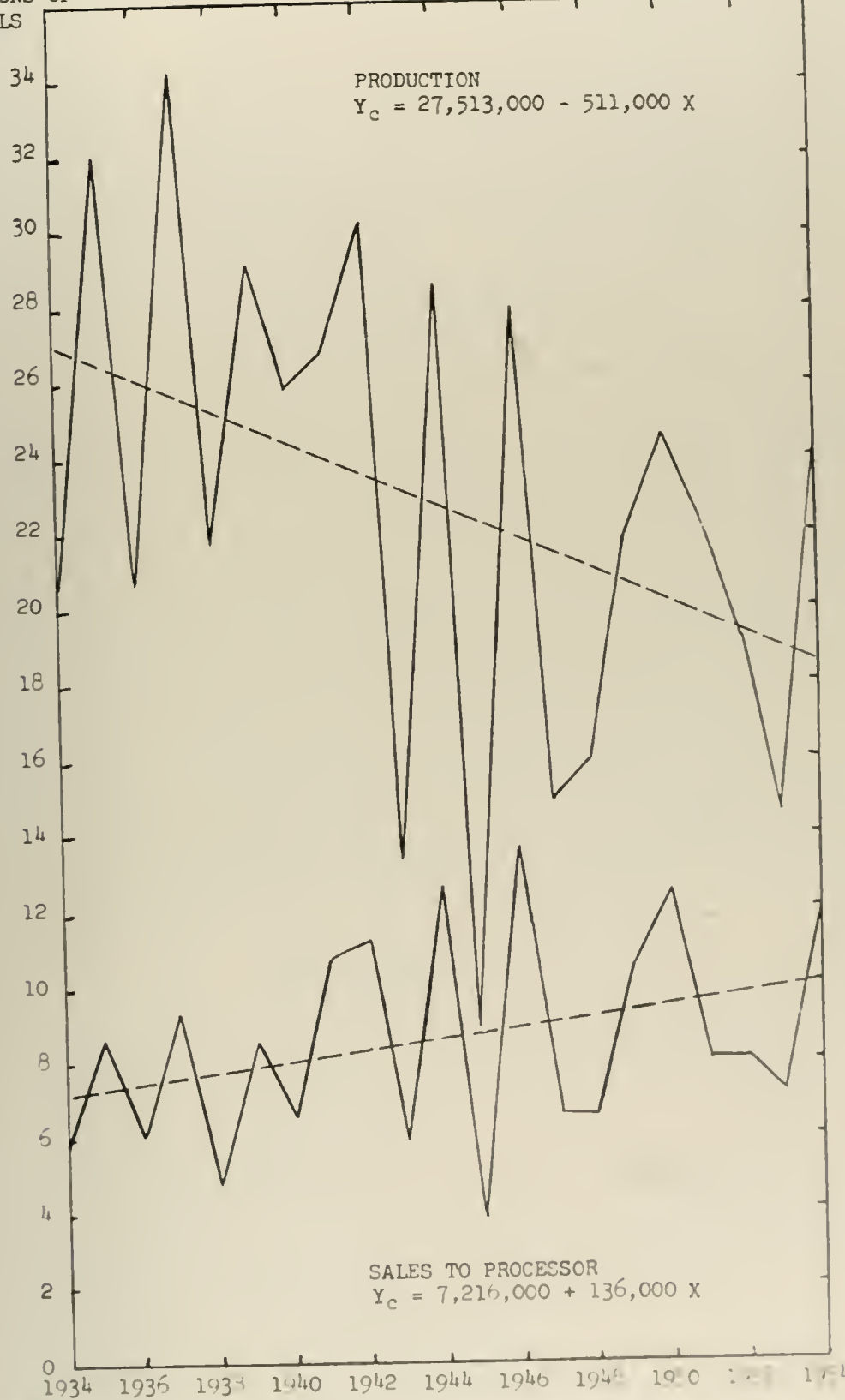

FIGURE 5. Apples-production and trend in production of commerciol crop; soles to the processor and trend in sales, Appolochion Arco, 1934-54. (Source: United Stotes Deportment of Agriculture, Crop Reporting Boord.) 


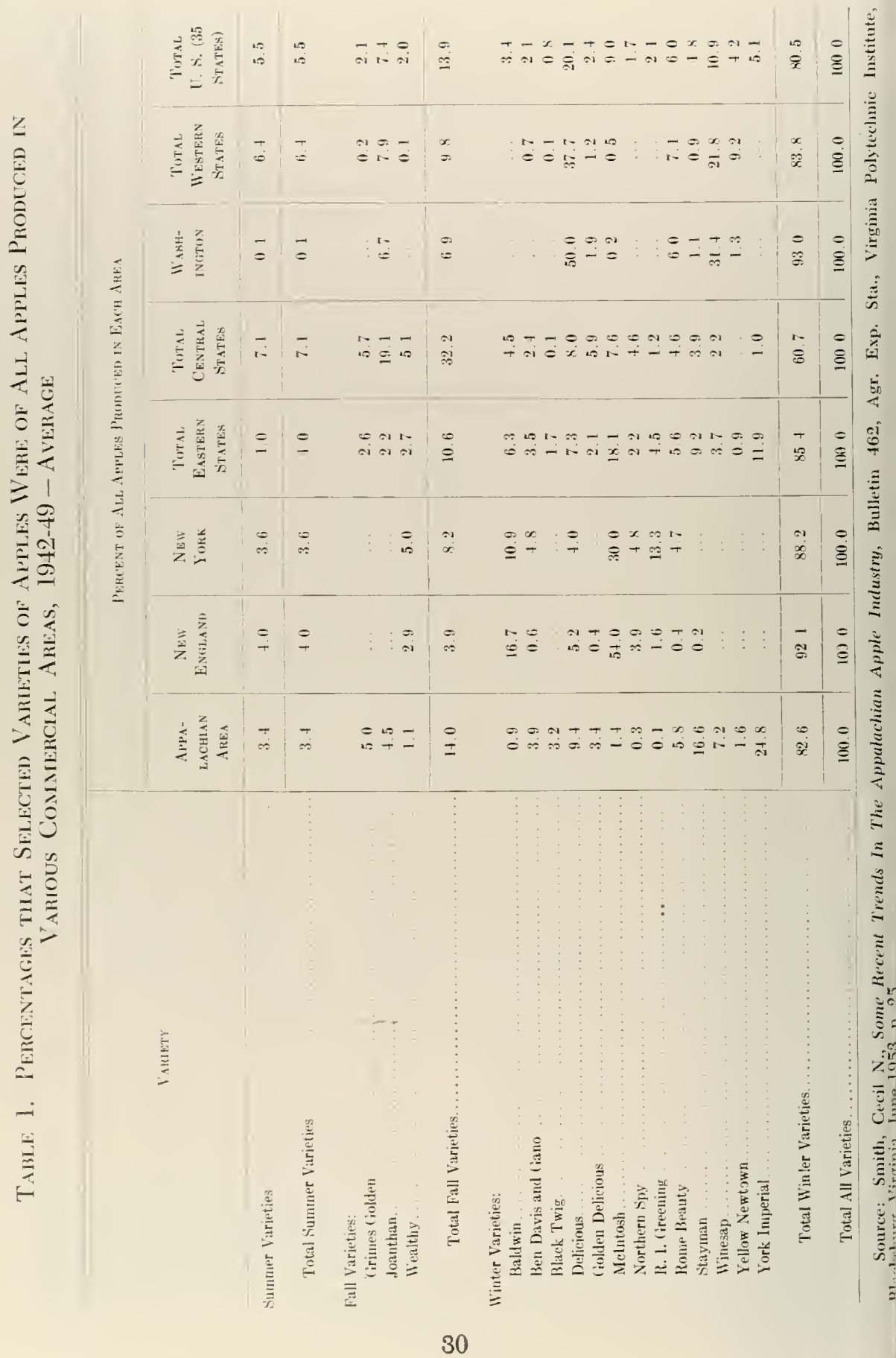


Table 2 gives the utilization of eight varieties in the Appalachian Area for the $1950 \mathrm{crop}$. Even though processors prefer certain varieties for processing. some like to use a blend of many varieties in making applesauce. Due to yearly variations in variety production. blending enables processors to produce a more uniform product than would be possible with only one or two varieties. Although some varieties are preferred for processing and others for the fresh market, all are used by both outlets. Price is important in determining whether apples will go to the fresh or to the processor outlet.

\section{THE PRODUCTION OF APPLE SLICES AND SAUCE}

Applesance and slices account for a considerable part of all apples processed and have increased in importance over the past nineteen years. Figure 6 shows sauce and slices as a percentage of all processed apples in the United States. In the Appalachian Area applesance and slices are more important than they are over the United States as a whole. Figure 7 gives this relation. Sauce and slices are important to apple processors in the Appalachian Area, and this area also is a major sonrce of supply for the nation. Table 3 gives the total pack of sance in the United States and the percentage packed in the various areas. The Appalachian Area supplies approximately one-half of the supply, followed by New York and California.

Table 4 gives the total pack of sliced apples in the United States and the percentage packed in the various areas and states. Again the Appalachian Area is a major source of supply, producing alont one-half the total. It is followed by New York, Washington, and Oreegon.

\section{Summary}

The Appalachian Area procluces about onc-fiftl of the national commercial apple crop. Production has been declining both in the United States as a whole and in the Appalachian Area. There has been an increase in sales to processors during the past 20 years. Production of sance and slices has expanded, particularly that of sance. In the Appilachian Area approximately onc-half of the crop has been solel to the processor outlet in recent years. Also, about one-half of the national prexluction of sance and slices is from the Appalachian drea.

It is with this production and ntilization data, and the theoretical concepts ontlined in Chapter 11 as a guide that the tash of delineating the market suh-group insolving apple processors in the Aplodichian lrea is undertaken. 
Table 2. Production and Utilization of Selected Varieties Appalachian Area 1950 Season.

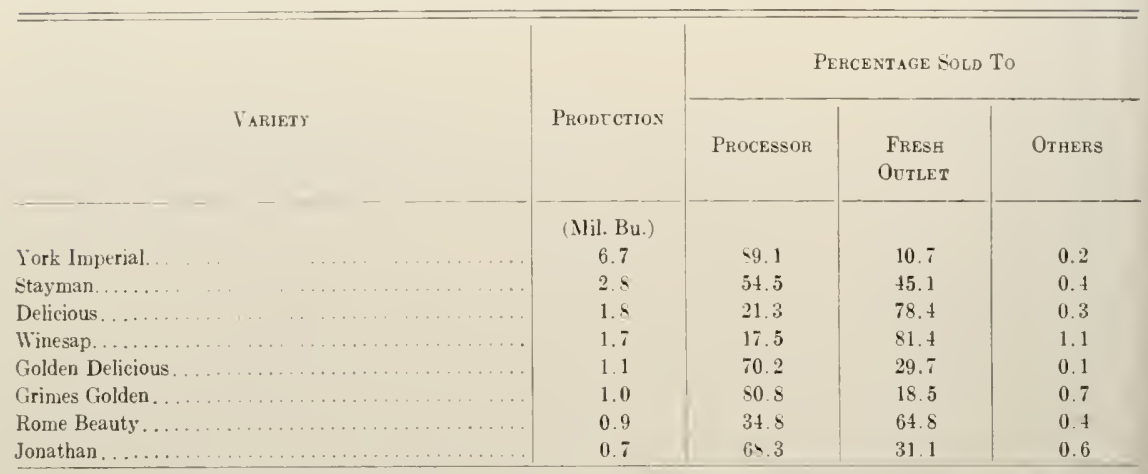

Source: Smith, Cecil N. Outlets Utilized by Cumberland-Shonandoah Groucrs in Marketing the 1950-51 Apple Crop, Bulletin 461, Agr. Exp. Sta., Virginia Polytechnic Institute, Blacksburg, Virginia, page 19.

Table 3. Applesauce - Total Pack United States and Percentage Distribution by States on Groups of States 1934-1954.

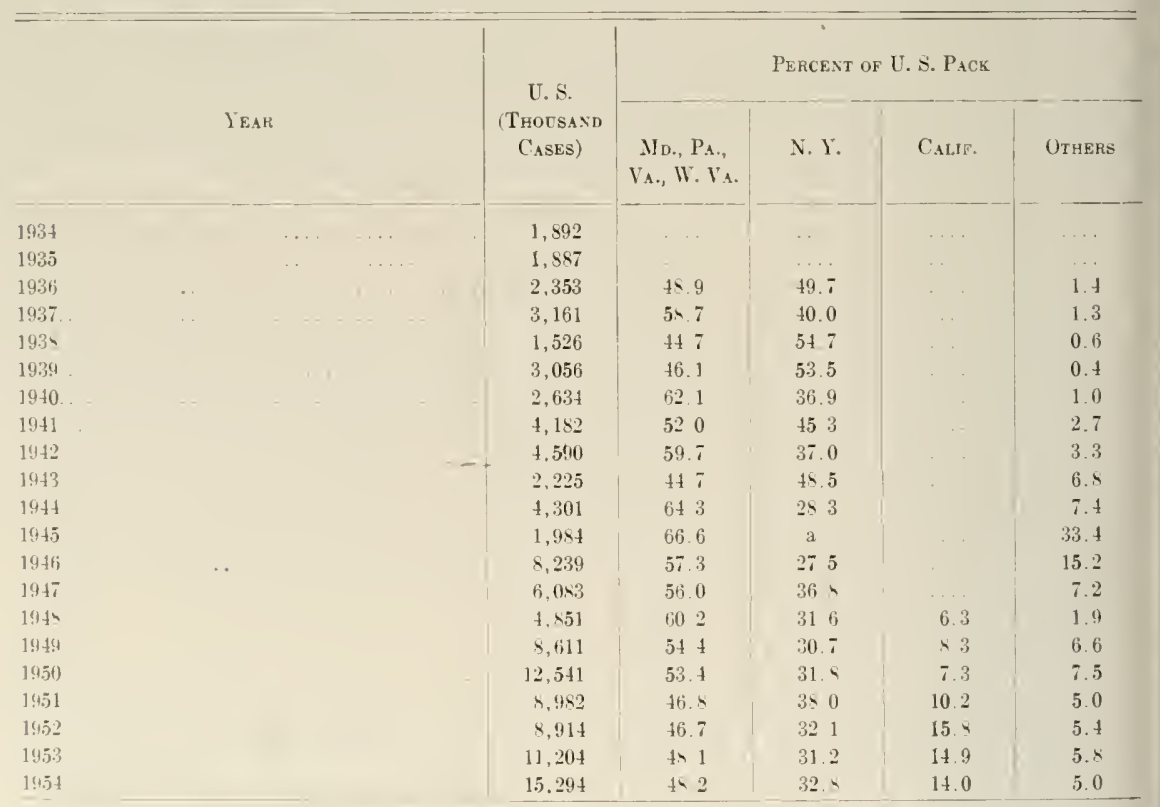

a = Included in other states.

Source: National Camers Association data. 


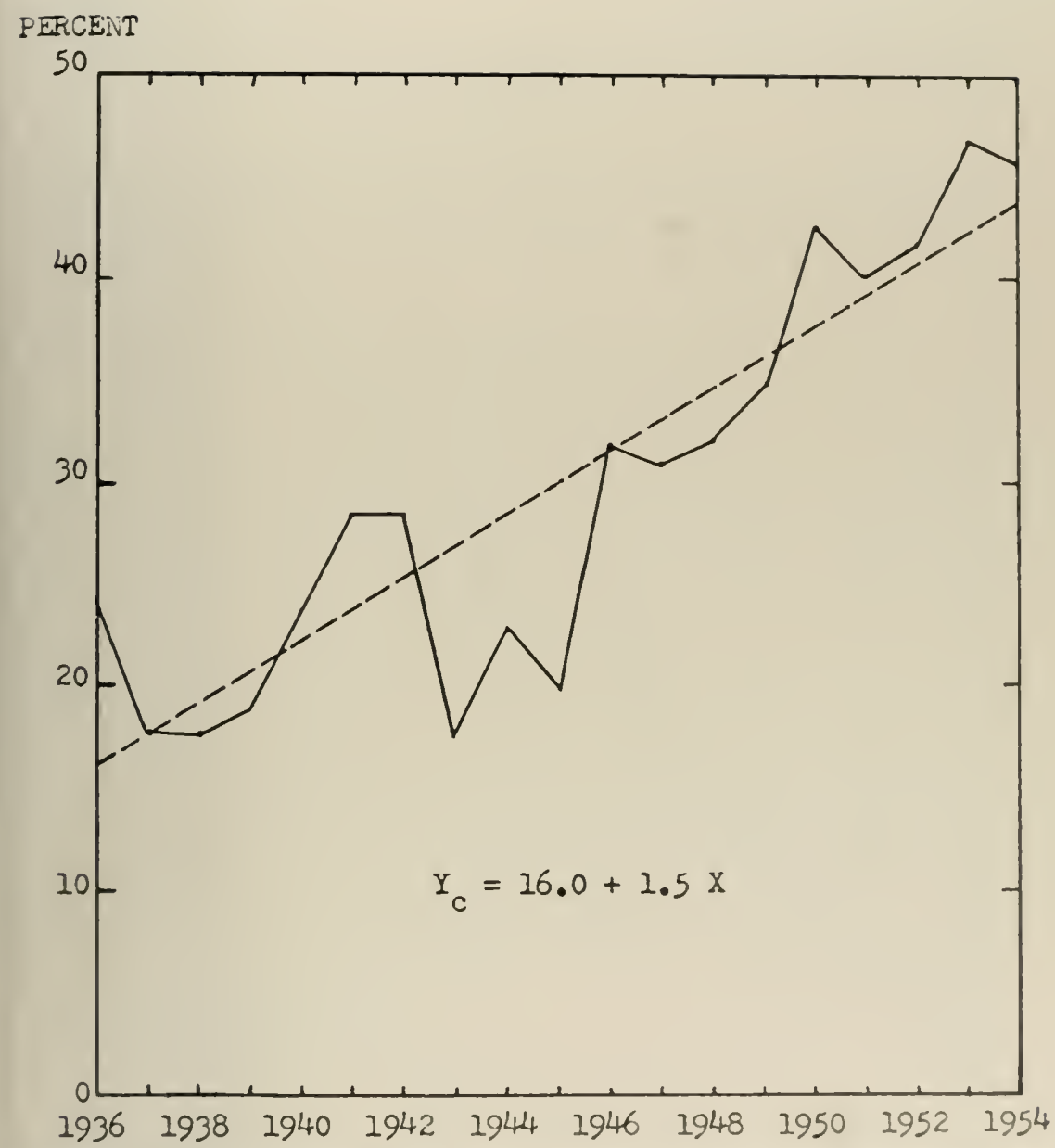

FIGURE 6. Applesauce and Slices as a percentage of all apples processed in the United States, 1936-54. (Source: Calculated from United States Department of Agriculture and Notionol Canners Association dato.) 


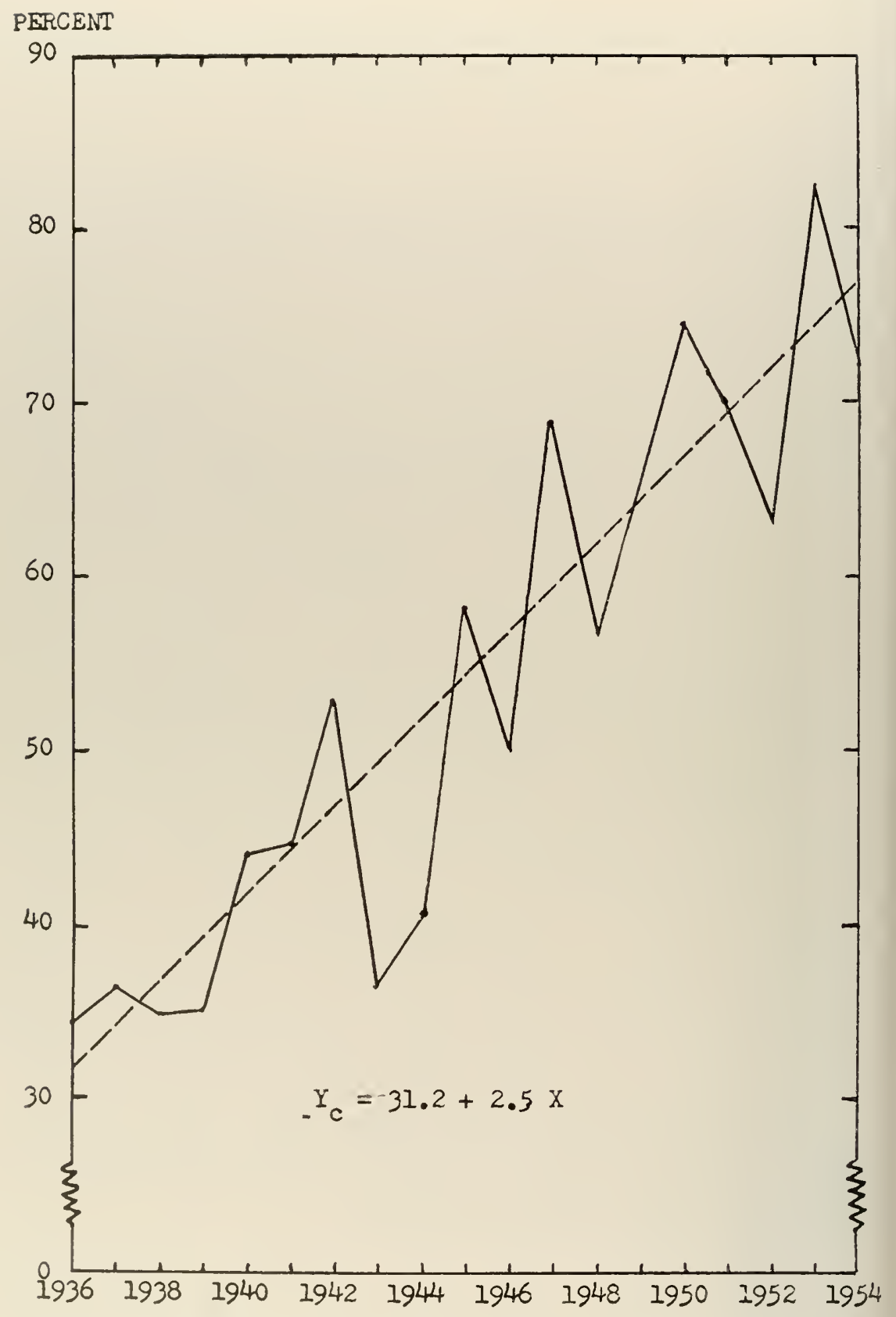

FIGURE 7. Applesauce and slices os a percentage of all opples processed in the Appalachion Area, 1936-54. (Source: Calculated from United States Department of Agriculture and National Canners Association data.) 
Table 4. Sliced Apples - Total Pack United States and Percextage Distributiox by States or Groups of States, 19:34-19.54.

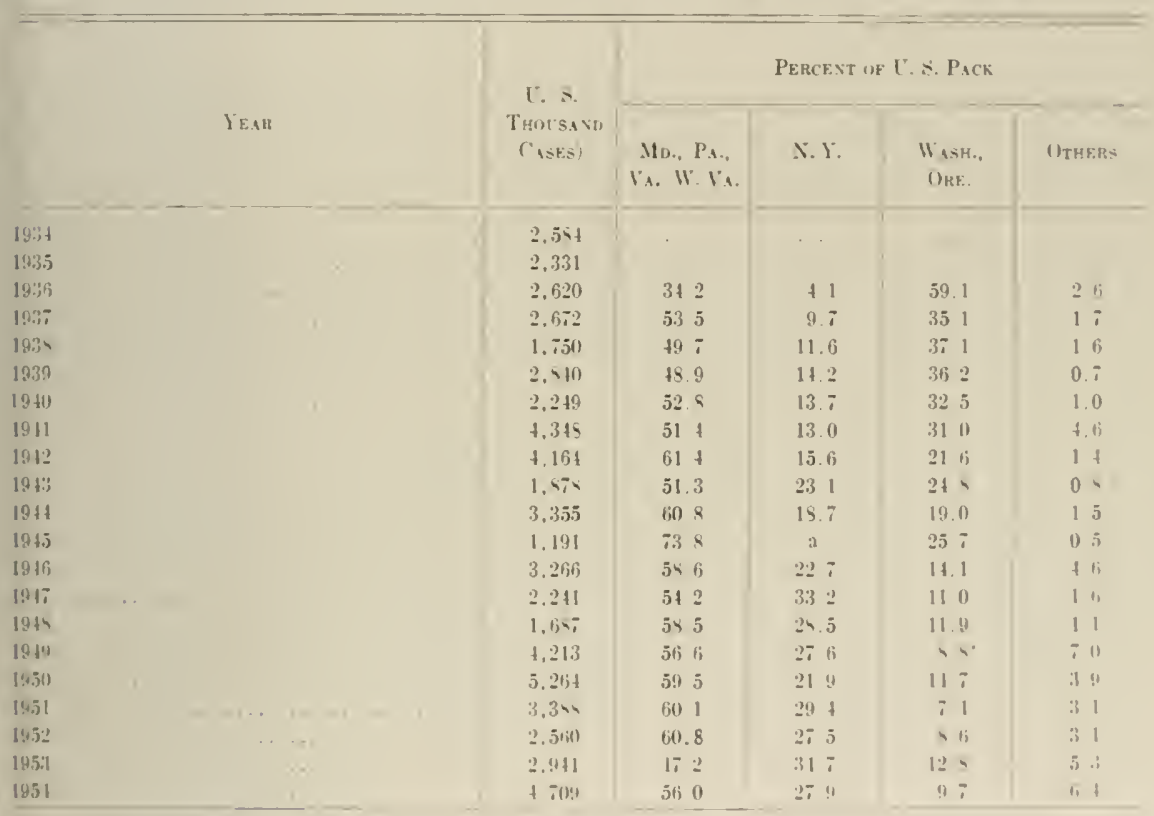

it = lachaded in other states.

Source: Vational Cammers Asveciation data. 



\section{Chapter IV}

\section{DELINEATION OF THE MARKET SUB-GROUPS INVOLVING APPLE PROCESSORS IN THE APPALACHIAN AREA}

RITERIA for including firms in any particular market sub-group were outlined in Chapter II. They are: (1) any two firms must sell or buy substitute products, and (2) all firms must have similar structural patterns or be in the same industry. In Chapter III a rather general historical background of the production and utilization of apples was presented. This chapter is concemed with the problem of delineating the market sub-groups involving apple processors in the Appalachian Area.

In a market sub-group there are both buyers and sellers. As a point of departure, apple sellers will be considered first.

\section{Apple Sellers}

In using the concept of a cross-demand curve as a device to delineate the boundaries of a market group, it is necessary to select an anchor firm to which the cross-demand curve is to be linked. ${ }^{19}$ If the cross-demand curve between the anchor firm and any other firms under consideration is positive, the firms involved are in the same mathet group. Any apple grower selling apples to processors in the Appalachian Area may be taken as an anchor firm.

\section{SUBSTITUTABILITY}

Assume that farmer A represents any apple grower-seller in the Appalachian Area. If farmer $A$ cuts the price of his apples, does he affect the quantity sold by other farmers (sellers)? If so, what others? Does he affect only those in the Appalachian Area, all in the ciast, or all in the United States? In order to answer the curestion of substitution, it will be helpful to assume that farmer $A$ cam make an! priece chutuge effective, that is, supply the yuantity of apples mecessary to satists all huyers at the price announced. 
This assumption facilitates the determination of the degree of substitution of the products of two firms. The ability of any firm to affect the sales of the others will be examined when their power relations relative to numbers and sizes are analyzed. Therefore, for purposes of this study, this assumption facilitates the separation of the substitution effect and the power effect due to numbers and size.

There are many market places in which farmer A may sell his apples: (1) to fresh buyers in the Appalachian Area, f.o.b.. orchard; (2) to processor buyers, f.o.b., processing plant; and (3) through any one of many central wholesale markets, f.o.b., central market. Usually apples are sold on the basis of U. S. Grades and Standards, regardless of types of outlet (fresh or processor) or market place. Grades standardize apples: that is, they classify apples by variety, quality and size.

Assume that the f.o.b. Appalachian Area price for U. S. No. 1 Stayman $2 \frac{1}{2} 2^{\prime \prime}-3$ " in diameter is $\$ 3$. per bushel. Assume that farmer $A$ cuts his price to $\$ 2.50$. Will farmer A's cut in price affect the sales of other apple growers? The answer is yes. Other sellers of that grade, variety, and size will find it difficult if not impossible to make sales. Consequently buyers will shift to farmer A. The effect will be not only on one particular grade, variety, and size but also on the sales of other grades, varieties, and sizes. Under conditions of equilibrium, in any market place the prices of the different grades, varieties, and sizes have certain relationships to each other. Once this equilibrium relationship is broken by a change in the price of a particular grade, variety, and size the equilibrium is disturbed for the other grades, varieties, and sizes.

Wholesale apple buyers may be described as experts in that they usually insist on inspecting and comparing alternative offers before every purchase. Buyers are paid to exercise their expert judgment and ability to get the utmost out of every transaction. ${ }^{00}$

Since farmer A sells apples both in the Appalachian Area and in many of the central wholesale market places throughout the United States, it is immaterial in which market place he cuts price. Table 5. The same substitution effect results among sellers and among different varieties, grades, and sizes of apples. Similar expertness among buyers will be found in all market places. When farmer $A$ sells in the various central wholesale market places, he is not only selling in competition with other Appalachian Area apple growers but with those from all major producing areas in the United States, Table 5. The substitution effect will be the same for sellers from other areas as for sellers from his own.

Enor a fuller discussion as to the expertness of buyers in the wholesale markets see: Tibor Scitovsty, Wrifare and Competition, The Economics of a Fully Employed Economy. Richard D. Irwin, Inc., 1951, p. 17. 


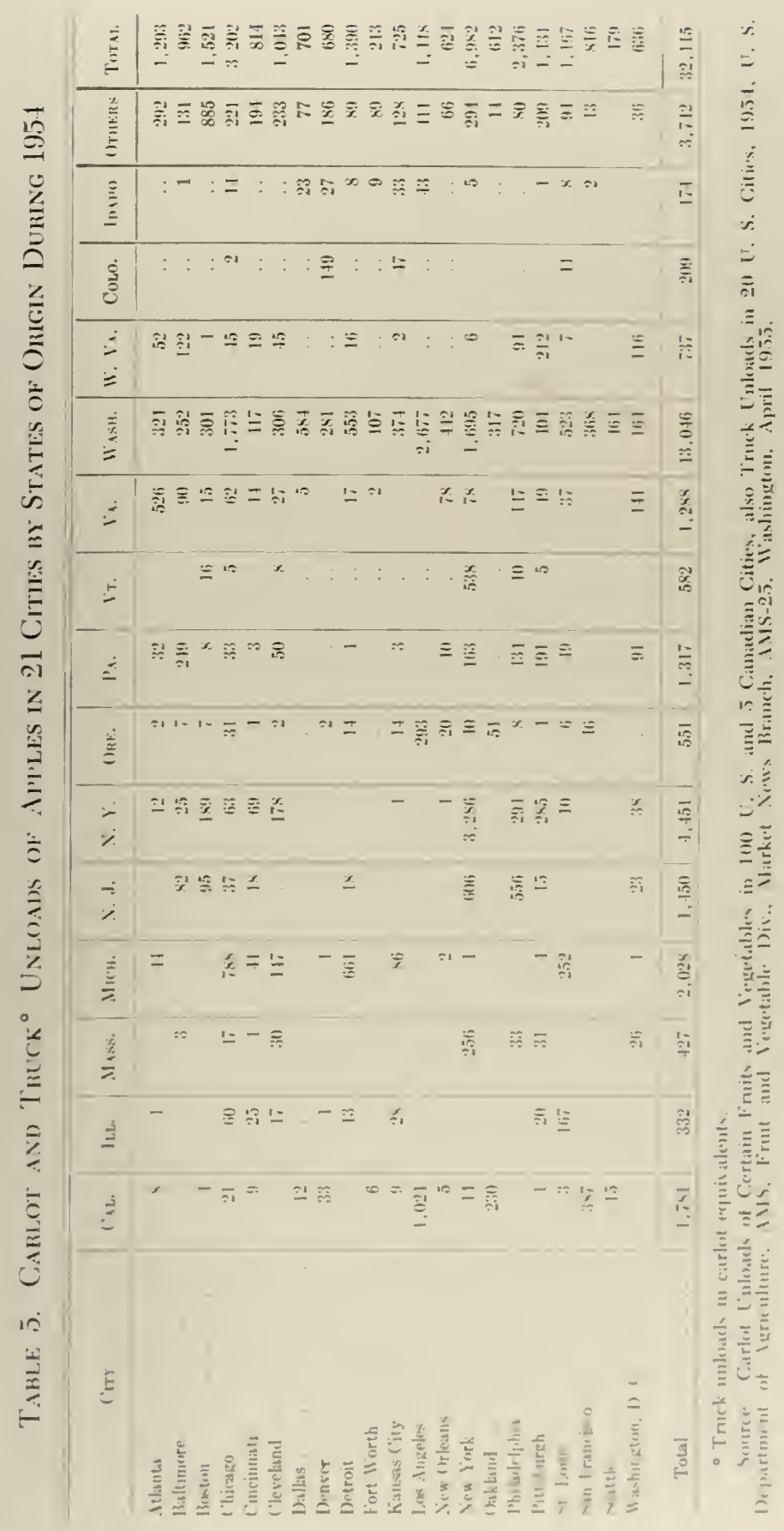


The prices of all grades, varieties, and sizes of apples are closely related and tend to move together due to the high degree of substitution. Also, different market places are tied together by apple sellers substituting one market place for another. For example, if farmer A can realize a higher f.o.b. orchard price for his apples by selling in Chicago than by selling in Atlanta, he will tend to substitute Chicago for Atlanta until returns are the same. In the same way he detemines whether to sell to the fresh or processor outlets. Therefore, all farmers selling apples are selling substitute products (apples). Due also to the wide distribution of apples from each producing area, all farmers selling apples are in the same market group.

It is realized that certain producers may enjoy a premium for their apples due to variations in location and costs of transportation. Also, since one apple is not a perfect substitute for all other apples, there will be differentials for preference differences. However, the range of these differentials will be determined by transportation costs and preferences for one apple over another. Consequently, the price of any one variety, grade. and size, at any given location, will affect the price which may be received for the same product in another location and the price for other grades, size, and varieties of apples at the same or other locations.

\section{INDUSTRY CONCEPT}

For any two firms to be in the same market sub-group they must have similar structural patterns and must handle substitute products. It was found that similar structural patterns usually fall along industry and product lines, because firms producing the same product or very similar products are faced with quite similar problems throughout their operations. In the production of apples, technological, market, and organization problems which confront farmer A are similar to those confronting all other apple growers.

Although apples are produced over a large part of the United States, the bulk of the commercial crop is produced in about three or four major producing areas, Figure 3 . The length of time necessary to establish a producing orchard is about the same in the different areas. The length of growing season and production costs present similar problems in the various areas. In some areas costs may be somewhat higher than in others due to irrigation, but in these areas yields will also be higher.

The weather presents many problems for apple growers. Frost, winter freeze, drought, and hail are some of the major problems. Cer- 
tainly the probability of any one of these occurring varies among areas. However, there may be certain offsetting effects. For example, winter freeze seems to be a greater hazard in the Pacific Northwest, and frost in the sprine is greater in the east. The amount of sunshine and temperature appears to affect the finish of the fruit. Some areas may be consistently farored in this respect. This would help to differentiate the fruit of these areas from the fruit of others.

It was found that the different producing areas sell through the same market place in many instances, Table 5. It also was found that some areas depend more on the processor outlet than do others. However, for any grower there appears to be a number of alternative market places available. The marketing problems confronting all apple producers are quite similar.

It is concluded that all apple growers are in the same industry and sell substitute products. This qualifies all such growers for the same market sub-group, as clefined in this study. This grouping of firms was not arrived at by a precise statistical quantitative procedure because the necessary data were not available; and if they were, such an analysis would be an almost endless process because so many firms are involved."1 Therefore. a decision to group all apple growers together must be subjective, based on the judgment of the researcher and on his huowledere of the performance and of the conditions confronting the firms under consideration. Before arriving at this decision the author disenssed with many growers, marketing men, and horticulturists the beloavior and problems confronting apple growers. $H_{c}$ also relied upon first-hand knowledge of the situation in the Appalachian Area.

This decision was reached with full knowledge that all apples are not perfect substitutes for each other, and that all growers are not confronted with identical problems, exen in the same comnty. Howerer, apples produced by a particular farmer are a rather elose substitute for those produced by other growers in the same areal and in other areas. The major problems confronting apple growers relative to the preducetion and marketing of their apples are also quite similar.

\section{SELLERS OF PRODUCTS OTHER THAN APPLES}

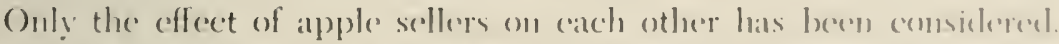
"What of their relationship with sellers of other products-unch as othere fruit? No doubt there is substitution between apples and other fouits.

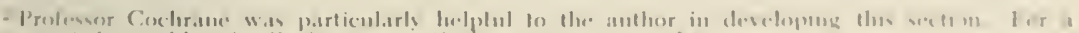

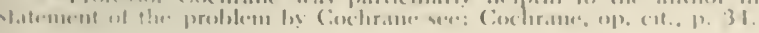


Consequently, this gives an apple seller a positive sloping cross-demand curve with sellers of other fruits. However, the degree of substitution is weaker than that among apple sellers, thereby making a break or gap in the degree of substitution. The substitution effect of other fruits can be handled by the elasticity of the total demand for apples rather than by bringing other fruits into the market sub-group. Doing so would complicate the problem without aiding significantly in its solution.

The concept of an industry becomes important at this point. All apple growers have similar structural patterns in that their production and marketing problems are similar. However, conditions are more homogeneous among apple growers than between apple growers and other fruit growers. Rather than bringing other fruit growers into the same market group, their effect can be injected through the demand curve for apples. Therefore, only apple sellers will be included in their market sub-group.

\section{POWER RELATIONS AMONG APPLE SELLERS}

The substitution between farmer A's apples and any other grower's apples is relatively high. However, before A can affect the sales of any other grower by a cut in price, he must be able to supply the demand at the lower price. Up to this point it has been assumed that farmer $A$ could supply the demand at the lower price. When this assumption is removed, and farmer A's ability to supply the demand is examined, it is found that he is unable to do so. Farmer A not only is one among many apple producers but for any particular variety he produces a quantity insufficient to influence price. In 1950 there were over 2,500 commercial apple producers in the Appalachian Area. ${ }^{-2}$ The 1950 Census of Agriculture reported over 1.5 million farms reporting the production of apples. ${ }^{23}$ A conservative estimate is that there are over 100.000 commercial apple producers in the United States. Therefore each grower produces an insignificant proportion of the total supply, even for one variety.

The power relation among apple growers is atomistic. Each grower is a price taker. He may decide how much to produce and sell, but he must take price as given. Even though there are factors which deviate from the pure competition model, apple growers in the marketing of their apples act basically as though they were selling under conditions

:Cecil $\because$ Smitin. Ontlets Utilized by Cumberland-Shenandoah Growers in Marketing the 1950-51 Apple Crop, Virginia Polytechnic Institute, Agricultural Experiment Station, Bulletin 46I, June 19.53

Census of Agriculture, 1950, Vol. 1I, General Report, Table IV, p. 680. 
of pure competition; that is, (1) each seller is so small relative to the market sub-group that he exerts no perceptible infuence on the price of apples; (2) entry is free and of no concem to those already producing and selling apples; and (3) knowledge is rather complete as to the alternatives available. 24

All apple growers find themselves in the same market sub-group, selling similar products, and competitive pressure is strong due to the mass action of all sellers. No one seller can follow an independent pricing policy; each seller must take price as given. He is a price taker. No seller is able to exert competitive pressure on any buyer.

\section{Apple Buyers}

In the Appalachian Area apple sales are about equally divided between the fresh and processor outlets. Fresh buyers will be considered first.

\section{BUYERS OF FRESH APPLES}

In determining the group of buyers which represents the demand side of the sub-groups, criteria are the same as those for sellers, namely (1) any two firms must offer substitute outlets for the product, and (2) all firms must have similar structural patterns or belong to the same inclustry.

\section{Substitutability}

It already has been stated that apple growers (sellers) will substitute one buyer for another over a wicle range of market places. An illustration may show how buyers in widely separated market places are substitute outlets. Assume that price is such that all market places for fresh apples are in equilibrim, and that no seller can switch from any one buyer to any other buyer in any market place and increase his foob. orchard returns for apples. Assume that firm il apple buyer in amy market place, for example, Atlanta, increases lis price. Becaune there are no restrictions on the movenent of apples between matret places. except transportation costs, and because price already was admuted for transportation before the price change by firm 1 , alpple greme will tend to shift shipments from other firms and other market placer to firm $\lambda$. This will continue until either firm A lowers its prices, or wher

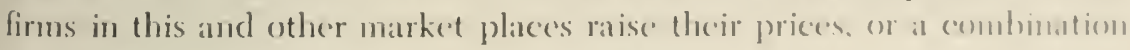

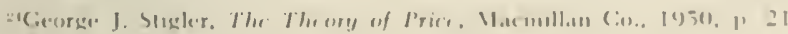


of both once again restores equilibrium.:- Therefore all fresh buyers offer substitute outlets.

\section{Industry Concept}

Fresh buyers have similar structural patterns in that they handle the same product and perform the same function. Some fresh apple buyers may handle only apples, and others may handle many products. However, firms which handle many products are confronted with problems similar to those confronted by specialists, as far as their apple activities are concerned. Consequently all fresh buyers belong to the same industry.

\section{Power Relation Among Buyers of Fresh Apples}

Due to the large number of buyers, each buying a relatively small volume of the total, and due to the high degree of substitution among buyers, their relationship is atomistic. That is, any one firm cannot make an independent price change, for it either will lose all its suppliers if it lowers price or be flooded with supplies if it increases price.

There is possibly one exception-the produce-buying activities of A\&P. ${ }^{26}$ However, part of A\&P's power and advantage is obtained through vertical integration. Therefore, it is difficult to ascertain the extent to which the power is obtained by buying apples at a price lower than other buyers pay: However, clue to the large number of alternative buyers and to the thousands of sellers, the extent to which $A \& P$ is able to obtain apples at prices lower than competitors is probably minor. Later it will be pointed out that chain store buying policies may affect the sellers of apple products.

Competition among fresh buyers is similar to competition among apple sellers. Therefore the power relation is atomistic and each buyer is a price taker. Again the pure competition model best describes the situation, although there are deviations from this model.

\section{PROCESSOR BUYERS}

Processor buyers are important to apple sellers in the Appalachian Area. In recent years they have purchased approximately one-half of the crop in the area.

2Naite and Trelogan, op. cit., p. 157; "The price of a good at one place cannot exceed the price of the same product at another location by more than the cost of transfer between the two places, except when the difference in price is unknown, or temporarily before a transfer of the product can be made." Federal-State Market News Service for apples daily reports price in leading market places.

2:Papandreou and Wheeler, op. cit., pp. 281-291. 


\section{Substitutability}

Figure $S$ gives the location of the plants of six processing firms in the Appalachian Area. All the major plants are located within a radius of approximately 75 miles of Martinsburg, West Virginia. These firms buy apples on the basis of U. S. Grades and Standards for processing. Therefore, it is relatively easy for growers to make comparisons of offers among the processors.

The cross-demand curve of any two firms will be positively inclined. In other words, all firms are substitute buyers for apples in the Appalachian Area and subject to similar forces of supply. The price that any one processor offers affects the quantity offered to any other processor in the area.

Are processors in the Appalachian Area and those in other areas subject to the same forces of supply? The answer probably is no. Processors have their facilities located in specific areas and depend on local producers for their supply of apples. The net cost of marketing processed apple products is less if the apples are processed in the production area. Consequently, apples are processed near the point of production in order to reduce their weight, bulk, and perishability:

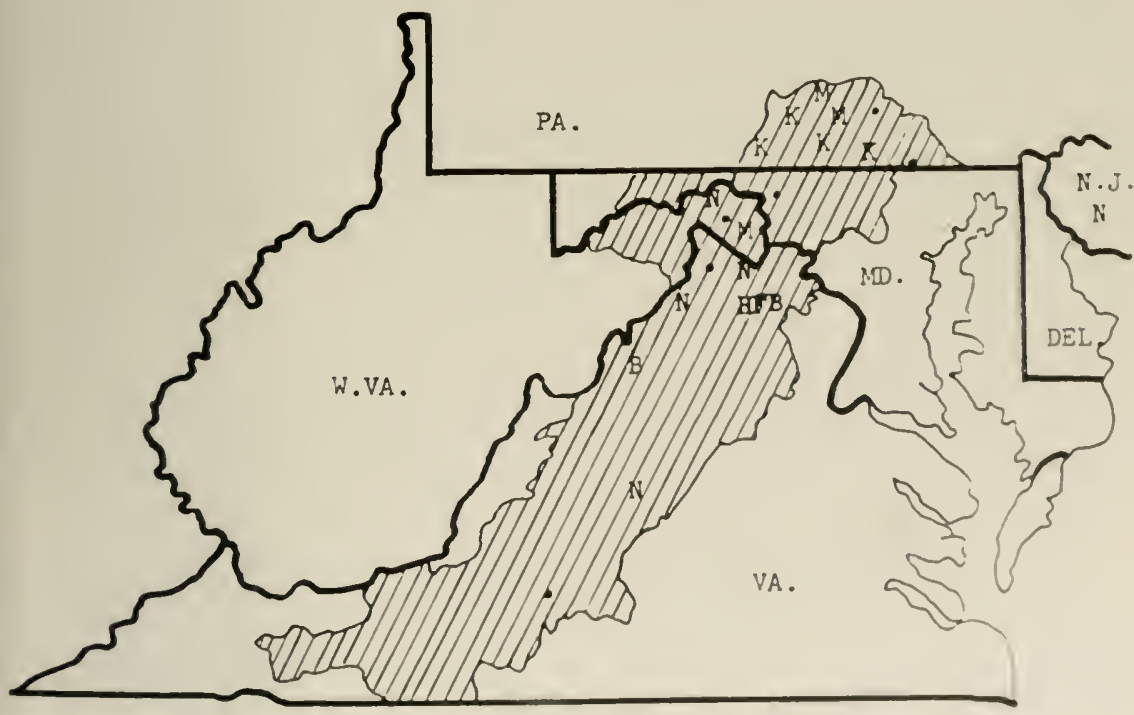

LEGEND: $M=$ Musselman; $N=$ National; $K=$ Knouse; $S=$ Shenandoah:

$H F B=$ Byrd; $B=$ Bowman.

FIGURE 8. Location of processing plants in the Appolachion Area. 
At this point the problem is to determine the nature of the relationship between the price paid by different processors: for example, the effect of prices paid by processors in the Appalachian Area on the supply of apples arailable to processors in New York, the closest apple processing area. An illustration will best demonstrate that relationship.

Assume that prices are in equilibrium and that processors in the Appalachian Area are paying $\$ 0.80$ per bushel for processor apples and receiving ten million bushels-that the average $U$. S. fresh price is $\$ 2$. per bushel and buyers are receiving 80 million bushels. Also assume the elasticity of supply to processors in the Appalachian Area is unity and that the elasticity of demand for fresh prices is also unity. ${ }^{27}$ Now assume that processor A in the Appalachian Area increases price 20 per cent to \$0.96. Since all processors in the Appalachian Area are located relatively close together and buy on the basis of U. S. Grades and Standards. other processors in the area will have to increase their price immediately or lose virtually all their supplies. Apple sellers will now sell the processors 12 million bushels. The resultant increase of 2 million bushels means that fresh supplies are reduced by a like amount; 2 million bushels is 2.5 per cent of fresh sales. This means that fresh price will increase by 2.5 per cent to $\$ 2.05$. Therefore, the fresh buyer will have a relatively minor adjustment, whereas the other processors in the same area will have a significant adjustment. The New York processor will be affected by only a 2.5 per cent increase in fresh price. This assumes that there is full and complete adjustment. In actual operation such a move by processor A might go relatively umoticed by fresh buyers and processors in other areas due to the penumbra within which market prices fluctuate. ${ }^{2 s}$

Therefore, the price paid by processors in the Appalachian Area has little effect on the supply available to processors in New York. This statement may be broadened to include all processors outside the Appalachian Area, since other areas are more distant than New York.

Therefore, all processors do not meet one of the requirements for being in the same market sub-group. That is, the price paid by any one processor in the Appalachian Area does not significantly affect the supply offered processors in other areas.

"The nature of the elasticity of supply and demand is considered in Chapter I. Indications ire that the elasticity is greater than unity. However, it is assumed to be unity here to simplify the illustration. Tn the extent that it is greater than unity processors in one area will have leis affect o: thove in $x t^{2}$ ser area than shown in the illustration.

w Waite and Trelogan, op, cit., 1). 91. 


\section{SUBSTITUTABILITY BETWEEN FRESH AND PROCESSOR BUYERS}

Does the price paid by apple processors in the Appalachian Area affect the supply of apples available to fresh buyers? The answer is yes. It will be demonstrated later that the quantity of apples received by processors is determined largely by the relationship of processor price to fresh price. The grower is interested in his net return for apples. Therefore he will take into consideration any differences in the cost of marketing in determining through which outlet to sell.

In the Appalachian Area, during the period 19:34-54, the arerage gross return to growers for sales to processors was $\$ 0 . \$ 0$ per bushel and \$1.9:3 per bushel for sales to fresh buyers. From a sample of growers taken in 19.51 it was found that it cost growers from $\$ 0.96$ to $\$ 1.2 S$ per bushel more to sell to the fresh outlet than to the processor.":! In the particular year, 19.51, returns from sales to processors averaged $\$ 0.60$ and from fresh sales $\$ 1.79$. When fresh marketing costs are subtracted from fresh prices net returns vary from $\$ 0.51$ to $0 . \$ 2$, making f.o.b. orehard returns about the same from both outlets.

This evidence verifies the point that fresh and processor buyers are substitutable in the case of apple sellers. Therefore, processor-luners in the Appalachian Area and all fresh buyers are subject to the same forces of supply. However, the relationship is much closer among processors than between processors and fresh buyers. Processors depend on local supply and there are only a few local firms involved. On the other hand. fresh buyers draw their supply from several producing areas and many buyers are involved.

\section{Industry Concept}

Are all processors in the Appalachian Area confronted with similar problems? The answer is yes. The operations of all are similar. They buy from the same growers and sell to the same buyers. They produce similan if not "identical" products. Variation in size of operation and type of ownership has no appreciable effect on the type of problems confronting the various firms.

Are processors and fresh buyers confronted with simular probleme and therefore do they belong to the same inclustry? The amwer is mo. Fresh buycrs purchase for immediate sale without changing the apples form, whereas processors buy in a frow weeks the amemut that they sell over a period of a year or more. They also change the form of the fruit. The cost of apples is only a part of their total cost. Containers. matmu-

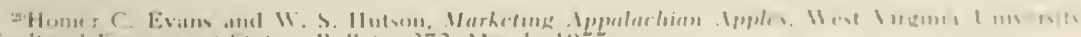
Agriculemral 1 > 
facturing, storage, and other costs must be considered by processors. The power of the fresh buyer has been described as atomistic, but this may not be true for the processor buyer. Therefore, fresh and processor buyers are confronted with different problems and do not belong to the same industry as defined in this study.

\section{POWER RELATIONS AMONG PROCESSORS}

In the case of apple sellers and fresh apple buyers so many firms are involved that their relationship is atomistic. Consequently, there is no need to identify the numerous sellers and buyers because they cannot influence price individually. Therefore, the behavior of any one is of no concern to the others. This is not the case with processor buyers in the Appalachian Area. Consequently it will be necessary to identify the buyers and know something of their relative size, of their operations, and of their behavior.

\section{CHARACTERISTICS OF PROCESSORS}

In recent years six processors have accounted for the purchase of the bulk of the apples processed in the Appalachian Area.

The C. H. Musselman Company (Musselman), National Fruit Product Company (National), and Shenandoah Valley Apple Cider and Vinegar Corporation (Shenandoah) were in operation prior to 1934. Bowman Apple Products Company (Bowman) began operation in 1939; H. F. Byrd, Inc. (Byrd) in 1948; and Knouse Food Cooperative Inc. (Knouse) in 1949. Table 6 gives the relative volumes of purchases by these processing firms for certain years from 19.34 to 1954 . Data are not available for all years.

Table 6 shows that in recent years the processors listed have accounted for the purchase of most of the apples used in the area for processing. but in earlier years they accounted only for slightly over 50 per cent. The six processors listed are engaged principally in the production of sauce and slices, which in recent years have become more important relative to other products, Figure 6 . Dried apples were much more important in the thirties. They were processed mainly by many small operators for whom no data are available.

Applesance and slices are the principal apple products produced by these leading firms, but not all the apples can be used in this manner. According to Hunt of National it was found that it required from 142 to 168.9 pounds of number one camning apples to produce 100 pounds of apple slices." Apples 23/4 inches in diameter and up required $1+2$ pounds, and apples $2 \frac{1 / 4}{4}$ inches in diameter required 168.9 pounds. The

"Lnpublished report, 1949. 
loss is eomposed of peel, core, seed-cell trimmings and clefect trimmings. Although these trimmings are not usable for sauce and slices, they may be used for vinegar juice, cider, jelly, pectin, and pomace. In addition to the above by-products from U. S. No. 1 camning apples, some of the apples are not suitable for sauce and slices and must be used for other products. Therefore, even though these leading firms are engaged primarily in the production of sauce and slices, they must dispose of the by products, which accounts for part of their income. Table $T$ gives (for Musselman) the percentage of total sales accounted for by sauce and slices and by all apple products.

Table 6. Pencentage Distribution of Purchases diong Tarlous Processing Firdis, Appalacinax Area 19:3t-1954.

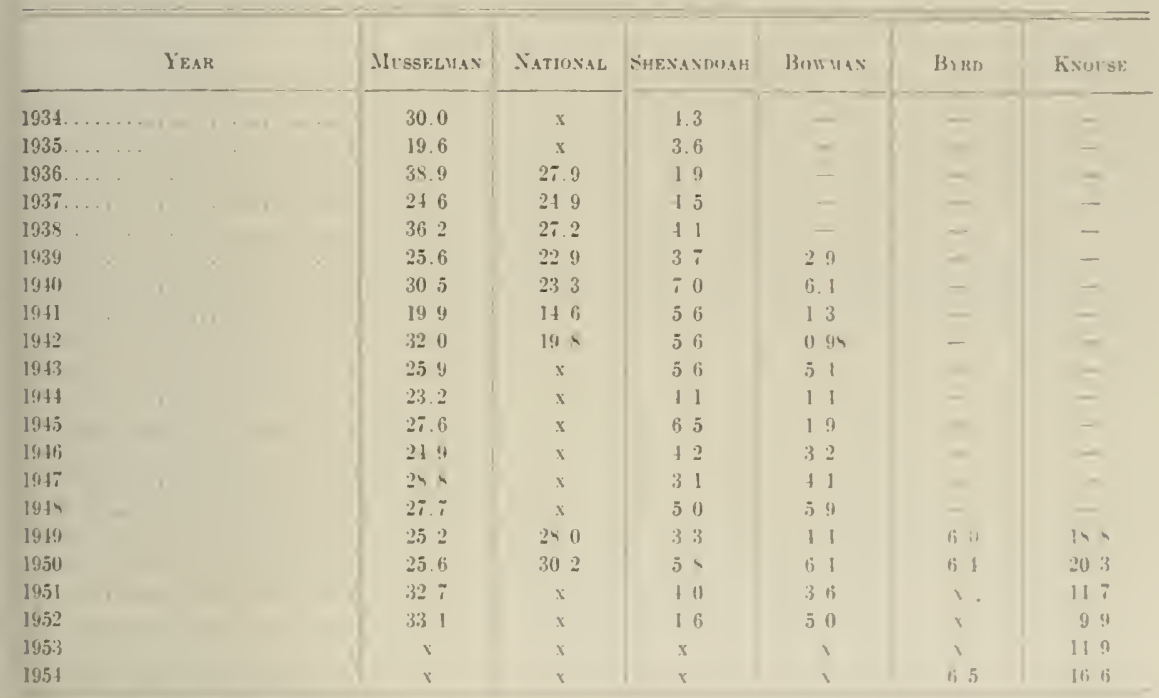

- = before firm itarted processing

$x=$ d.ita not al alilable.

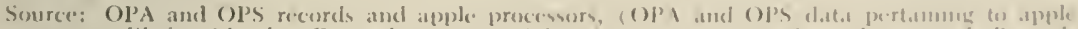

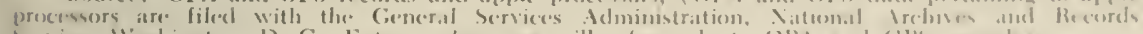

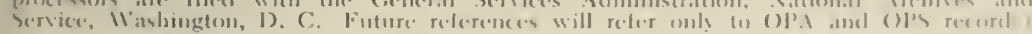

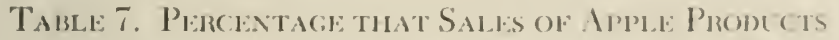

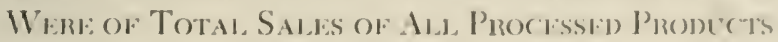
BY MUSELLMAN, 19:37-43.

\begin{tabular}{|c|c|c|}
\hline Vi:All & 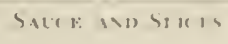 & 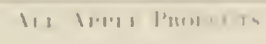 \\
\hline $19: 37$ & 52 & (1)" \\
\hline $19.3 \mathrm{~s}$ & 12 & (1) \\
\hline 193!) & 3.1 & 114 \\
\hline 19.11 & $6 i 2$ & 4 \\
\hline 19.4 .3 & (i) & 4 \\
\hline
\end{tabular}

Source: ()I'1 recerris. 
The increased volume of tomatoes and cherries largely account for the decline in the percentage sales of all apple products in 1940 and 1943. Musselman is the largest purchaser of apples for processing in the Area, areraging 28 per cent of all purchases, Table 6 .

National purchases almost the same volume as Musselman, averaging 24.3 per cent of all apples purchased for processing, Table 6. In 1942 sauce and slices accounted for 33.9 per cent of National's total sales, and all apple products accounted for 97.4 per cent. ${ }^{31}$

Shenandoah averaged only 4.7 per cent of total volume and less than one-fifth the volume of the two larger firms, Table 6 . Shenandoah produces primarily applesauce and slices. Shenandoah is a private corporation, but some of its operating policies make it unique. Arthur, of Shenandoah, testified before the FTC examiner that 75 to 80 per cent of all apples used by that firm were normally supplied by the owners of the corporation. ${ }^{32}$ Nany of the owners or members of their families work in the plant.:3 He also commented that it did not matter whether net earnings were distributed as a return on stock, as a bonus to apple suppliers, or in the form of higher wages and salaries, for the same people benefit in any case. (This would be true only if ownership, apples supplied, and wages were closely correlated for each individual concerned.)

Bowman started processing in 19:39. From 1939 through 1952 Bowman's purchases averaged 3.4 per cent of all sales to the processor. Bowman purchased a higher percentage during the latter years. Bowman, like Musselman and National, is a private corporation.

Byrd entered the processing business in 1948. It is an integrated operation, owned by the largest apple grower in the area and it processes apples grown by the owner and by members of the immediate family. It is estimated that Byrd processes about 6 or 7 per cent of the apples in the area.".t

Knouse started processing-apples in $1949 .{ }^{3}$ It is a cooperative corporation. supplied by approximately 400 apple growers throughout the Appalachian area. In 1949 and 1950 Knouse processed approximately one-fifth of all apples processed in the area, only slightly less than Vusselman and National. However, in 1951 and 1952, it processed only 14.7 and 9.9 per cent of the total, respectively; but in 1953 and 1951

OOPA records.

FTC Docket, No, 6041, p, 1256

331 bid, p. 1299 .

The Vew lork Times, Section 3, p. 1, November 6, 1955 isisee Appendix p. 98 for the historical background of Mr. Knouse and Knouse Foods
Cooperative, Inc. 
it processed 14.9 and 16.6 per cent, respectively; Table 6 . In the case of Knouse, Bowman, and Byrd a higher proportion of their total sales are in the form of sance and slices than in the case of the other three firms.

\section{SUMMARY OF POWER RELATIONS AMONG PROCESSORS}

Six processors buy most of the apples for processing in the Appalachian Area. The two largest buy approximately one-half; a cooperative takes about one-sixth; and the remaining one-third is taken mostly by three smaller firms. One of the three smaller firms operates very much like a cooperative, and a second one is integrated with the production operations of one of the largest apple producers.

The power relations among processors are different from those found among either apple producers or fresh apple buyers. It appears that Musselman and National have a circular power relation between each other and a dominant power relation with that of some of the smaller firms. While in some years Knouse had only a slightly smaller volume than Musselman and National, its operating policies differ.

In establishing price during the marketing season Knouse can make adrance parments on apples and may set price goals as to what it hopes to pay growers. However, final settlement for the apples camnot be made until the season's operations are completed. The competitive pressure that Knouse brings on other firms may have a greater long-run than short-run effect. In other words, its operating policies may dimpen the immediate effects of its competitive pressure. Ilowever. this dampening effect may be partly offset by Knouse setting price goals. Throngh past performances these goals may be considered ats the expivalent (1) a firm price, thereby, in the short rum, applying competitive pressure on other firms.

Some of the smatler processors possibly feel unable to affect the purchases of others by a change in their own price. Therefore. the prower relation anneng the smaller processors is atomistic, whereas that between the smaller enes and larger ones is one of dominanee be the latrere firms.

It is easy for sellers to make a comparisom of price betwerol burem. as purchases by all processors are made on the basis of U. S. Ciractes and Stamdards, and prices are ustrally anmenuced in advance of deliscry. Processors are located comparatively close logether, and one is abont as eomvenient an outlet as another. Usmally processors lny from andone desiring to sell at the annomeed prier. Uneler thense conditions the powere relations are determined largely by redative size and eapsacils 
The excess capacity of some of the processors is comparatively high. There are only a relatively few firms in the sub-group. Apples may be stored rather easily before processing, and after processing they may be stored at low cost. Capacity may be increased by adding more shifts to existing plants. This point indicates a rather high clegree of circularity. However, excess capacity in terms of circularity is a relative matter and may be of no importance to relatively small firms.

In summary, the power relations among apple processors functioning as buyers of apples are either circular or dominant. The relation between the larger firms is circular, and between the larger firms and smailer ones dominant. The relationship among the smaller firms may be atomistic. Only a few firms are involved and the nature of competitive behavior is determined by their decisions. It has been argued that if certain conditions are present a particular pattern of behavior may be found. The degree of substitution and the number of firms in the market have already been considered in arriving at the hypothesis that their power relationship is a combination of circularity and dominance. It is further argued that if the power relation is other than atomistic, the presence of a cooperative in the group and the ease of entry affect the nature of competition.

\section{Cooperative}

Knouse is a cooperative. Shenandoah's policies give it many of the characteristics of a cooperative. Byrd is an integrated operation, which makes its similar to a cooperative in some respects.

\section{Entry of New Firms}

Papandreou and Wheeler classify restrictions on entrance into five categories: "(1) terms on which technological data and technologies are made available; (2) terms on which factors of production are made available; (3) terms on which outlets for the product are made available; (4) consumer allegiances; (5) outright legal restriction."36 In view of these restrictions entry should be relatively free in the apple processing business.

There appear to be no trade secrets in the apple processing business. Growers switch from one buyer to another for a slight premium in price. There are apparently no strong ties between growers and buyers. Consequently, factors of production are available on the same terms to new firms as to established firms; however, if established firms take aggressive action toward new firms, conditions will become less favorable for all firms. Established outlets and consumer allegiance may make conditions

Papandreou and Wheeler, op. cit., p. 179. 
slightly more farorable for existing firms. This advantage is reduced by: the use of buyers' labels. There are no outright restrictions in entry: Consequently, entry is relatively easy:

\section{Summary of Market Sub-Groups Found In the Appalachian Area}

Firms are in the same market sub-group if they meet two requirements. First. the cross-demand (cross-sales) curve between any pair of firms must be generally-positively inclined. For buyers, the cross-supply (cross-purchase) curve between any pair of firms must be generallydownward sloping. Second, any pair of firms must have similar structural patterns or be in the same industry. Industry grouping usually falls along product lines, and all pertinent conditions confronting the firms in the industry are similar. Using these criteria for delineating sub-group) boundries, the following groups involving apple processors in the $A_{p}$ palachian Area are found:

1. Apple growers (sellers) in the Appalachian Area are in sul)groups made up of all commercial apple producers in the United States. They are price takers, and their relationship among each other is best described as atomistic. The pure competition model best describes their hehavior.

2. All fresh buyers in the United States are in the same market sub-group. They are also price takers, and the pure competition model best describes their behavior.

3. All processor-buyers in the Appalachian Area are in the same market sub-group. There are only a few buyers involved in this subgroup. They are price makers, and some form of imperfect competition best describes their behavior. A cooperative is present, and contry is relatively easy.

This completes the rather broakd and gencral grouping of buying and selling market sub-groups for apples in the Appalachian Area. Igain it should be emphasized that these groupings are based on what is hnown about the marketing of apples and upon personal judgment.

The only place in the marketing system where there appears to be a lack of competitive pressure is in the sub-group made up of processors buying apples. Conseguently, the remainder of this study will be denoted to determining the extent to which there is competitive pressure in this sub-group and to determining the facters responsible cither for conmpetitive pressure or for the lack of competitive pressure. 



\section{Chapter V}

\section{DESCRIPTION OF OPERATING POLICIES AND CONDITIONS CONFRONTING PROCESSORS}

$\mathbf{N}$ order to analyze the competitive behavior of apple processors in the Appalachian Area, it is necessary to know something about the nature 1 of the demand and supply relations confronting the group. This information will give some idea of the external conditions confronting the firms in the market sub-group.

\section{Nature of Demand and Supply For Processors}

\section{NATURE OF DEMAND}

The demand of processars for apples is derived from consumers demand. In other words, it is the average revenue for apples, derived by cleducting the average costs of processing and distribution from the average gross revenue from apple products. ${ }^{37}$ Therefore, the elasticity of the demand of processors for apples is dependent upon the elasticity of consumers' demand for apple products and upon the nature of processing and distribution costs. If processing and distribution costs are constant, the demand for apples will be less elastic than consmmers demand for apple products. ${ }^{3}$

The total demand for food is rather inclastic. Also, the demand for some individual food items is elastic. Fox found that the demand for apples in the United States at the farm level has an income clasticity of 1.32 and a price elasticity of -1.27 .39 Price and quantity datit necessary to calculate the elasticity of the demand for apple products are not a vililable. Howerer, certain generalizations relative to the nature of the demand may be made from what is known abont the sitnition.

Throughout the FTC hearing conceming the apple processom in the Appalachian Area numerons references were made by processem to the many close substitutes for apple products. Apparently the comsumer alue

3i Nicholls, op). (it.. p. T.1.

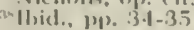

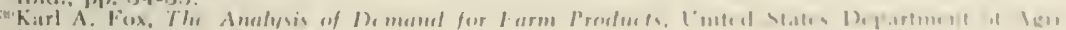

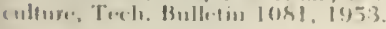


feels that there are many good substitutes for these products. Such a situation gives an elastic demand for apple products.

A high proportion of sliced apples is used in pies. The following quotation from Hunt points up the substitutability between fresh apples and camned apples: "We are competitive with the fresh market on our sliced apples and we had a considerable portion of our pack up and fruit committed for and if the trend continued as it was, the fresh market was likely to become further clepressed, which would give us tremendous competition from the fresh market on our slices; that did happen. I know an account that we normally ship the equivalent of 30,000 bushels of apples to, in the form of slices, that we lost entirely because they were able to buy fresh apples in the fresh market cheaper." ${ }^{\prime \prime \prime}$ Frequent references also were made to the alertness of pie bakers to changes in relative costs of different ingredients.

Hunt also made reference to the many substitutes for sauce, and to the point that sales were responsive to price changes. Apple products, like fresh apples, are substitutable for many other products. Fresh apples are also highly substitutable for apple products. This substitutability is due in part to the fact that fresh apples can be made into apple products. Therefore, it is logical to conclude that the elasticity of the derived demand for apple products is as great, or greater, than is the elasticity for fresh apples, estimated by Fox to be -1.27 .

Federal quality standards are widely used by processors of apple products. This tends to standardize the products. Also, processors of apple products never have made wide use of their own labels or brands. In the Appalachian Area some processors sell more than 80 per cent of their canned products under the buyer's label. The Farm Credit Administration found, in a study of cooperative processors, than 68 per cent of the canned noncitrus fruits and juices were sold under the buyer's label. ${ }^{41}$ Such policies make the product of one processor almost a "perfect" substitute for that of other processors. This makes the demand for the apple products of a particular area more elastic than for the nation as a whole.

Therefore, it is logical to conclude that the elasticity of demand for apple products confronting processors in the Appalachian Area is greater than that for the nation. The nature of the supply of apples available to processors in the Appalachian Area will be considered next.

4"FTC Docket No. 6041 , p. 651 .

"Anne L. Gessner and Edward C. Collins, Marketing Canned Fruits and Vegetables Processed by Cooperatives, 1948-49, Farm Credit Administration, U. S. Department of Agriculture, Washingtoll. D. C., Miscellaneous Report 151, June, 1951. 


\section{NATURE OF SUPPLY}

Processors in the Appalachian Area depend upon local producers for their supply of apples. The supply in the Appalachian Area at the begimning of any given marketing season is fixed, or the supply curve is perfectly inelastic at any price above the cost of marketing. However: this is not the relevant supply curve for processors. The supply of apples available to processors is determined largely by their price relative to fresh price.

It has been argued that the price for fresh apples is established for the nation as a whole under conditions characterizing pure competition. It also was argued in Chapter II that processors in the $A_{\mathrm{p}}$ palachian Area may consider fresh price as given, in that processors could have very little effect on fresh price through their own action. within the range in which they nomally operate. Starting with fresh price as given, the quantity of apples received by processors in the Appalachian Area is determined largely by the price of apples for processing relative to fresh price. A rough approximation of this relationship is presented in Figure 9. The solid line represents an index of the ratio of processor prices to fresh price in the Appalachian Area, and the broken line represents an index of processor purchases to fresh purchases. Both indices are expressed on the basis of $19: 34$ as being 100. The two generally move together with sales tending to fluctuate more than price. This inclicates that the supply curve confronting processors in the Appalachian Area is elastic. It also indicates that over the perind 19:3454 , sales tended to increase proportionally more than price. However. there is a need to examine the adecpuacy of these figures for showing the nature of the supply curve confronting processors.

The period from 1942 to 1947 was influcinced by the war. Price controls were in effect during part of the time. Shortages of materials and government orders to be filled also influeneed the quantity processed. The prices used in Figure 9 may not reffect accurately the prices growers consider in determining which ontlet to use. For example. fresh price was the average for the season. However, doring the first two months of the season growers determine how they will matret the lunlk of their crop. It is pointed ont elsewhere in this stucly that growers switch sales from one processor to another for as little als five conts pere hundred. It also is probalole that they may switch from fresh to processor for a small amount berause growers are interested in the net returns they receive for apples. There have been oceasions when the processors have opened witly a price low relative to the fresh price and therefore received few apples wntil they adjusted their price npwad. On 
other occasions the processor price has been high relative to fresh, and processors were "flooded" with apples. The 1950 season represented such a situation.

Figure 9 gives a rough approximation of relative price and sales. However, it may understate the elasticity of the supply confronting processors. During the time that growers determine how they will market their apples, the elasticity of supply available to processors should be rather elastic.

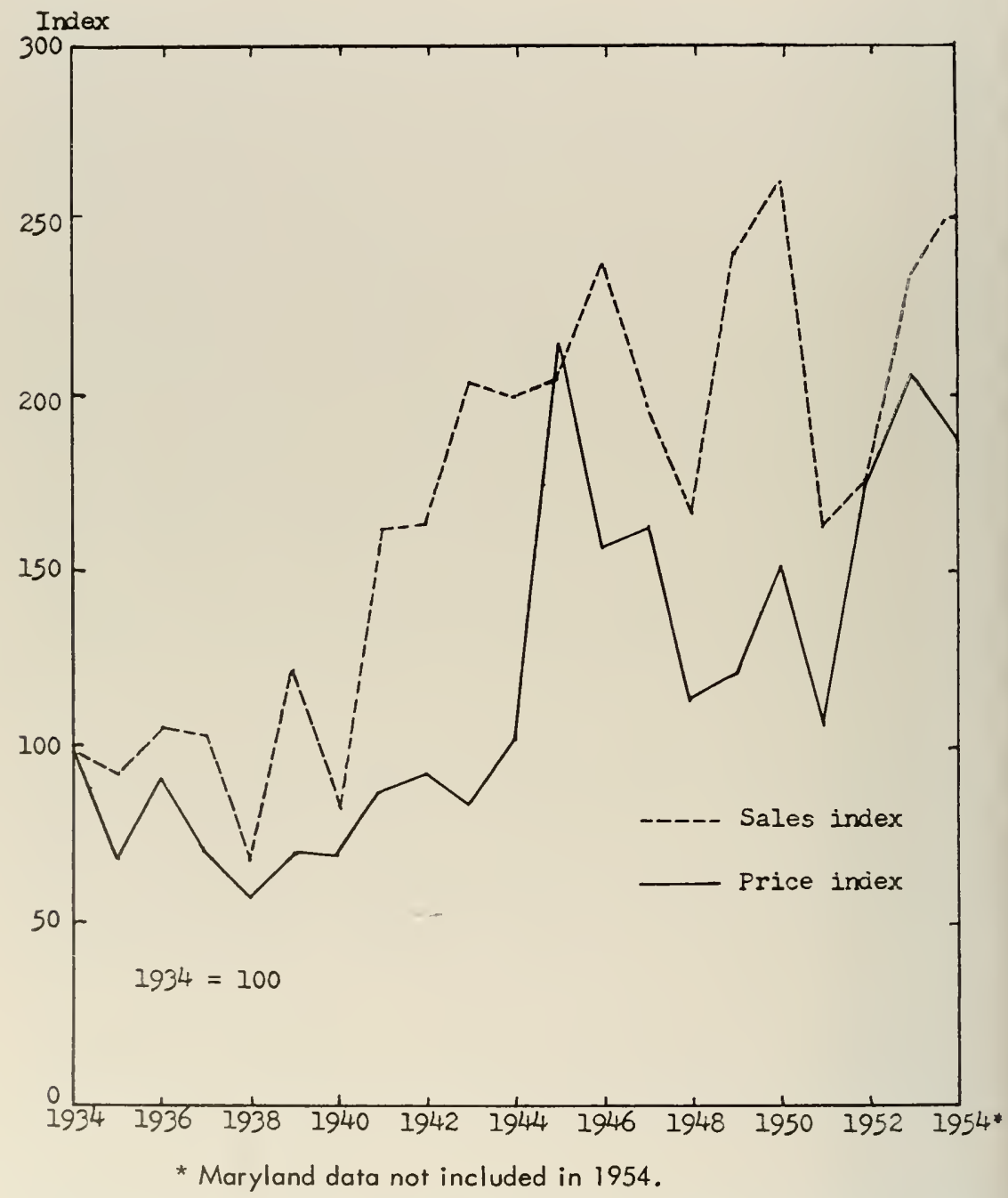

FIGURE 9. Indices of rotio of processor prices to fresh prices and of ratio of processor soles to fresh soles, Appolochion Areo, 1934-54. (Source: Colculated fram U. S. D. A. data.) 
In summary. the bulk of the evidence points toward an elastic supply of apples and an elastic derived deinand for apples confronting apple processors in the Appalachian Area. With this as a background an examination is made of the activities of processors in procuring apples.

\section{Procurement Policies of Processors}

The environment and firm characteristics found in the Appalachian Area as they affect the behavior of processors are briefly reviewed. There are approximately 2,500 commercial apple producers in the area. In recent years they have produced about one-fifth of the national crop and have divided their sales about equally between processors and fresh buyers. The relative price offered by the two outlets largely determines the division of sales. Thus the supply available to processors is elastic, assuming that fresh price is given.

\section{PRICE POLICIES}

One firm announces an opening price, and all others follow with the same price. In 1947 National announced its price September 16, and Musselman followed September 17."2 In 19-4S .Musselman announced its price September 9, and National followed September $10{ }^{4.3}$ On October 11 National increased its price, and Musselman followed October 12." In 1949 Musselman announced its price August 29. and National followed August $30 .^{4.5}$ Musselman announced its opening price August 28 in 1950; National's price list carried the same date. ${ }^{4 ;}$ These are typical examples of opening price announcements by Mussehman and National.

Shenandoah and Bowman follow the price announcements of Vussehman and National with similar if not identical prices. Bord is an integrated operation and does not announce a price. Knouse. beiner a cooperative, follows a slightly different pattern. After the other processors have amounced their prices, knouse usually announces that it will make an advance to growers at the time they cleliver their fruit. This advance usually is 50 per cent of a price nomally identieal to the price offered by other processors. As soon as the fruit is processed. Kuonse credits its patrons with another 30 per cent. At the ond of rach ammeal pool. Knouse, on a patrouage basis, distributes to patrom all receipts in excess of eosts. Receipts usmally hase beroll large enemer te make the total payment for apples more than the opening price of the

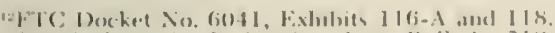

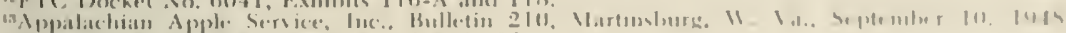

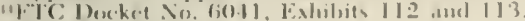

Ilicl, Exhilut 391 .

mIhid, Eslosluts fio and 6 l 
other processors. All of these payments may not be in cash, but part may be in some form of book credit and retained by the cooperative for a time on a revolving fund basis. ${ }^{47}$

This gives a general idea of the pattern followed in establishing a price at the beginning of a processing season. However, it does not necessarily tell the price at which apples are traded. Houser of Musselman made the following statement: "The price announcement that comes out in the early part of the season is not necessarily the price we pay for apples. I think in most cases they are called opening prices, and so stated in the price list on price announcements. There are many variables that come into the picture in the buying of apples."ts

The price announcement by Mussehman, previously referred to, dated October 12, 1948, was the ammouncement of an increase in price above the price list issued September 9. The latter announcement carried the following statement. "Because many of the growers, large and small, have delivered their apples to our plants before this change in price, we will make these prices retroactive to the beginning of the season." 4 !

Since the entry of the cooperative (Knouse) in 1949, the payment of patronage refunds by Knouse, and of bonuses by the other processors, have become a general practice. Apparently the price is broad enough to satisfy tax officials that a prior commitment for such payments was made, and that they may be excluded from the incomes of the firms concerned. The general interpretation among apple growers and processors is that the announced price is a minimum price, and that it may be increased.

Trial Examiner Hier made an excellent summary of the situation in his initial decision of FTC Docket No. 6041:

"If bonuses, allowances for freight, hauling, crates, storage, payments for culls and special 'deals' are all disregarded, the testimonv is abundant and uniform that apples were bought by all processors at identical prices for the same size and grade (Tr. 1043, 1046, 1082-83, 1247, 1292-93, $1357-64,1403,1411-12,1438,1461,1534,1185-87,1197)$. The uncontradicted and credible testimony is that the grower regards his orchard net as what he received for his apples. (Tr. 1935, 804, 209-10), and that even $5 c$ a cwt. has enough economic significance to switch business (Tr. 1514, $843-44,195-96,1691-92,534-35,594-95)$. The testimony is that the announced price is "just something the grower goes behind and makes his deal each time' (Tr. 1507-08), and is a base price, but not the price secured (Tr. 1216-38). There was competition in buying and in selling." ${ }^{50}$

The announced price may or may not represent the final settlement between growers and processors. Why all these special deals? Why not use a straight forward change in price, as under perfect competition?

${ }^{47}$ Taken from the testimony of Mr. Knouse before the FTC hearing. FTC Docket No. 6041, pp. 1742 to 1869

${ }^{45}$ FTC Docket No. 6041, pp. 1704.

451bid, Exhibit 113

${ }^{50}$ FTC Docket No. 6041, Initial Decision, p. 24 
The fact that there is not perfect competition is probably the reason. Each firm is attempting to differentiate its offer from the offers of others. Also, price is often quite powerful and effective. Papandreou and Wheeler have this to say on the subject:

"Price is the 'atomic weapon' of business. The news of a price cut spreads fast, and its effects, in general, can be estimated adequately. All the things that go into making a promotional campaign, in contrast to is price cut, have to do with molding people's tastes and attitudes. To one knows beforehand the extent to which a new slogan will affect the public. Ifonths of hard work may go to waste, whereas a flashy slogan picked out of the blue may produce spectacular results. Price cuts maty oftend leatel to all-out war, to conflict for survival. If firms are not inelined to engage in all-out war, they will awoid tampering with price except in a more or less guarded fashion. Higher levels of selling outlays and new ways of employing them in contrast, need not bring about it "do or die" struggele."

\section{Chamberlin has the following to say:}

"Because most prices involve monopoly elements, it is monopolistic competition that most people think of in comection with the simple word 'competition.' In fact, it may almost be said that uncler pure competition the buyers and sellers do not really compete in the sense in which the word is currently used. One never hears of 'competition' in comnection) with the great markets, and the phrases, 'price cutting,' indernelling," 'infitir competition,' "meeting competition," securing a market, e.tc.. alre unknown. No wonder the prineiples of such a market seem so unre.sl when applied to the 'business' world where these terms have meaning. The's are based on the supposition that each seller accepts the market prices and can dispose of his entire supply without materially affecting it. Thus there is no problem of choosing a price policy, no problem of adapting the product more exactly to the buyers' (real or fancied) wants, no problem of adverticing in order to change their wants. The theory of pure competition conld hardly be expected to fit facts so far different from its :ssumptions. " -

These two quotations indicate the importance of implicit price policies under conditions of imperfect competition. The fact that processors employ such practices supports the contention that there is imperfect competition among processors. Also, the absence of such policies amones apple sellers and fresh buyers support the lypothesis that the pure competition model best describes their behasior. An examination of some of the implicit price activities of processors is made neent.

\section{IMPLICIT PRICE POLICIES}

Cloclius and associates fomel that dairy processing fimm in 11 inconsin used varions nomprice devices in competing for producers mith. The? had this to say about the effectiveness of such practices:

"As stated earlicer a large majerity of the firms in this are $1.1 \mathrm{~m}$. and

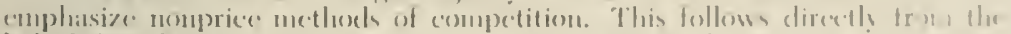

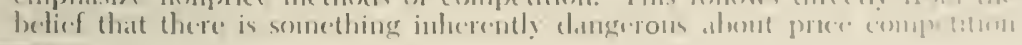

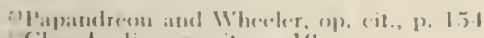

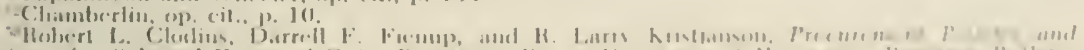

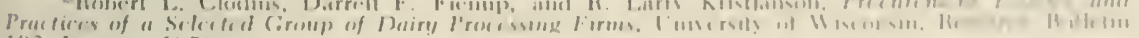

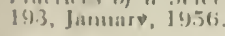


because of the repercussions which may occur as other firms retailiate. This emphasis on nonprice factors is also consistent with the fact that most finms stated that they seek to follow a price policy of paying average prices unless some unusual and individual price opportunity exists. The value of nonprice methods as a competitive device is enhanced where price differences are minimized. Also nonprice practices are generally considered effective only 'if the price is there' initially. Keeping individual firms' prices close to the average is a way of insuring that the "price is there." "st

The situation among apple processors in some respects is similar to that found among dairy processing firms. For example, apple processors tend to announce identical prices for apples and they make extensive use of various forms of implicit price devices to attract fruit to a particular firm. It was found, as Cloclius and associates learned, that these practices are effective. Once a practice is used by a particular firm it soon is employed by all firms. For example, 1949 was the first year of operation of Knouse. For that year's operation Knouse paid growers the prices paid by other processors and made a patronage refund in addition. ${ }^{5} \bar{n}$ Shenandoah, National, Bowman, and Musselman paid their suppliers a bonus. ${ }^{.6}$ Since then such payments have become general practice. The same pattern applies to other practices employed by processors, such as allowances for hauling, either supplying the grower with crates or paying him for the use of his own, and payments for storage.

When are these practices employed? They are employed when any processor is not getting all the apples he could use at the price being offered. Often they start as "secret deals" between individual growers and processors, but they fail to remain secret and soon become the genral practice of all. If the announced price is very far out of line, it is adjusted. The implicit price devices are employed for minor price adjustments and as an effort on the part of individual processors to differentiate their offers.

\section{LONG-RUN VIEW}

Processors seem to consider the long-run effect when they determine procurement policies. This long-run view is illustrated by the concern of processors over the long-run supply of apples, the entry of new firms, or changes in relative volume of existing firms. It already has been noted that the trend in the production of apples in the Appalachian Area is downward and the purchases by processors is upward. Such a situation eventually could make it difficult for processors to obtain supplies in the area. Such a situation could create pressure toward a relatively high price being paid by processors.

slbid, p. 29.

F'TC Docket No. 6041, p. 1864

Hid, Exhibits 121,122 and 123 , and pp. 1263, 1712 . 
In 1950 the price level paid by the processors was relatively high contrasted to that of apples for fresh use. Consequently, movement to the processors was heavy, relative to movement into the fresh outlet. Bowman testified before the FTC hearing relative to his ability to buy apples cheaper than he was paying and to take more apples than he originally planned to buy.

Mr. Miller. "How much did you wind up with?"

Mr. Bowman. "Approximately one million ..."

Mr. Miller. "Could you have bought apples cheaper?"

Mr. Bowman. "I could have bought apples for one-half of what I was paying." "s

Mr. Bowman's reason for taking more apples than originally planned was ". . . we felt an obligation to our growers in our community that had been furnishing us apples for years." "N The same year Hunt of National explained the situation as follows: "There was a large apple crop in 19.50; the fresh market was not good, collapsed, and as a consecpuence, more fruit flowed to the processing plants than had in 1.949 and previous years."." Rather than cut price, National borrowed 2 million dollars and continued to take fruit at a relatively high price.": Hunt also indicated that the reason for so cloing was to take care of their regular suppliers.

In 19.50 several factors affected the behavior of the processing firms. Due to the Korean situation it appeared that the demand for canned apple products might be musually strong. Also, this was the second year of oneration of the Knouse cooperative. In 1949 it had purchased 18.5 per cent of the apples for processing in the area and was expanding in 19.5). This also was the third year of operation for Byrd. Consorguently; there was a mixed feeling among processors whether to hold the price or ent it. Because new firms had entered the sub-group, all processors were reluctant to cut prices. They felt that it might affect achersely their relattimship with the apple growers. They already were losing suppliens to hinouse and felt that a price cut might cause further losses. Mlso, there was the feeling that a high price might discourage the neweromeres. Consecunently, all processors continued to hold the priece and pach the largest pack in histerry.

Processors tend to place much emphasis on the good will of the growers, and it seems that, in a competitive situation such as is found

H.T(: ) I

lind. 1p. 5.30.

Ilud, p. 6i21.

illut, n. (ii3.i. 
in the Appalachian Area, good will is one way of attracting fruit to a given plant. Therefore, it is important to maintain good relations with growers. Hauser emphasizes this in the following statement:

"We spend a good bit of money on a program we would like to call growers good will. Naturally we would like to have our growers friendly with us and over a period of years we have had meetings, dinners. educational meetings with county agents and state college people, state horticultural societies and what not, where we have tried to show our friendliness to the grower. When a year comes around when the price is going to be lower than the previous year it is not a pleasant thing to announce, therefore, I would like my competitor to announce and I would date my prices so that the competitor had his price out first. When the price is on the high side, I would like to have my price out first. ${ }^{61}$

"I might add that we are vitally concerned and I dare say most of the processors would be concerned as to the retention of orchards and the keeping of growers interested in growing apples, because we have tremendous investments in our plants and we must have apples for years to come and we cannot afford to let the growers get disgusted and go out of business because of not making money."6?

It seems that the same philosophy carries over to cutting prices once a price has been established.

The evidence is quite strong that the processors, particularly Musselman and National, take a rather long-range view of the situation in attempting to get maximum returns.

The implication of this section is not that Musselman and National have more freedom to increase price than to lower it, but rather that the consequences are such that it may bc more advantageous to raise price than lower it. However, they have the same freedom to lower price as to raise it.

\section{A Processor's Analysis of the Situation}

In completing this section of the study certain excerpts from a report by Hunt of National are presented. These statements represent how a particular processor responds to, or puts into operation. some of the factors discussed in this study. It should be kept in mind that Hunt made this report to a group of apple growers and was, quite naturally, interested in presenting a farorable picture for his firm. In 1954 processors announced their opening price about August 2.5 at $\$ .5$. per cut. for the best grade. About September 13 this price was reduced to $\$ 4.50$, and about October 15 it was reduced to $\$ 2.50 .^{63}$ Hunt's account of this situation follows:

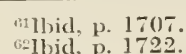

H. S. Stile's, Marketing Appalachian Apples, Summary of 1954 Season. United States Depart ment of Agriculture, Agricultural Marketing Service, Nartinsburg, West Virginia. 
"I think that 1954 will go down in the memory of the major processors of this area as the Season they tried to hold an umbrella over the Apple Deal in the Appalachian Area, only to have it spring torrential leaks on them.

"The fact that National Fruit led off with the first prices in this area probably accounts for my being asked to come here toclay and try to (xplain the past season and tell you what happened from the viewpoint of the processor.

"When we announced our prices on August 18th, wo knew very well that we were paying more for apples than we needed to, and were probably paying more than the law of supply and demand would justify. Subsequent events have proved this to be true. Now let me attompt to explain to you the reasons for our doing what we did.

"In the first place, we had just concluded a good season and were in an optimistic frame of mind.

"Secondly, processed apple products had been moving satisfactorily at high prices, for eximple, we were getting $\$ 1.85$ a dozen for No. 30.3 Apple Sance.

"In amnouncing the raw fruit prices, we said, and 1 quote, "Whether or not we can maintain these prices will depend upon both the processed and fresh fruit markets.

"A third reason for these prices was that the higher fruit prices and lower profit margin would tend to discourage some of the opportunist 'cut-price' processors. There are some processors in New York and alsu in this area who expand their packs far beyond their normal sales when they can buy fruit very cheaply or sell quickly at cut prices. Their operations almost inevitably have a depressing influence on the market. first, by increasing the supply beyond the demand, and then secondly, hy price cutting when they are not able to move their exeess pack quickly. ilaking it less profitable for these operators would tend to stabilize the nuarket for both the grower and the consistently operating processers.

"A fourth reason for these high prices wais that our 19.54 program called for twice as many Yorks as we were able to get in 1953. The 1953 (rop of Yorks was about $1 / 2$ of the " 52 Crop and " 52 was an "ON" year for lorks. So, coen though we realized the "5.t crop) was larger than 53.3 , we folt we would be justified in palying a gend price for Yorks.

"The next thing that we had in mind in making the prices as high as we did was to do away with the hamling allowances that lad come inter the deal during the previous seasom.

"We can't get any more for a can of simere processed from ipples that are hauled fifty miles than we get for ome made forme anples hianled five miles. If we pay more for the atpples hambed the fifty miles the we we hase (o) pily less for the apples hauled the five miles in order to atrorage out our conts.

"Every !ime you alserage out your costs, whether it be according to the distance hatuled, grade or size of the Iruit, you liske nuome? als als from the grower who has the shorter latul, or better or larger fruit and give it to

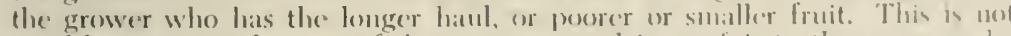
geod business on the part of the processer and is not fair to the grower whe

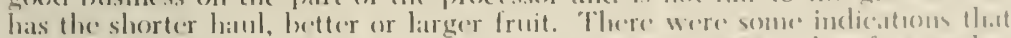

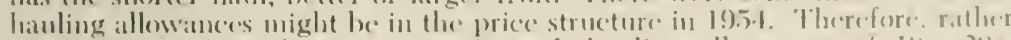
than have a price of $\$ .4 .50$ or $\$ 1.75$ with lambling allowimes of 11 ce. atle

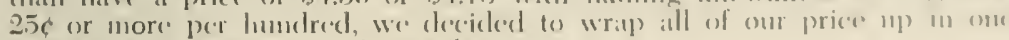
package and come out with une llat priece. 
"The last, and one of the most important reasons for the high prices was to encourage the planting and re-planting of more processing varieties, especially Yorks.

"We feel that the very hest way to sell your crop is to move only your very best quality and highest colored fruit to the fresh market and that the processing channel will be your best outlet of the future for the balance of vour fruit. Iowever, the quantity of this kind of fruit that can be processed will depend upon the quantity of Yorks that are available for blending purposes. It is, therefore, important to you and us that a proper balance be maintained between Yorks and the Dessert varieties. IV desired to encourage you to maintain this balance.

"That pretty well covers the reasons for what we did. Now, why didn't things work out satisfactorily?

"One reason that the beginning prices didn't hold was that the crop turned out larger than estimated nationally and in the major processing areas of Appalachia and New York.

"The first guesstimate of the crop, which was made by the leading growers in the various areas, placed the National crop at $97,450,000$ bushels, Appalachian at $20,240,000$, and New York State at 14,370,000 bushels.

"By August, when our decision was made, the various estimates varied from 101 to 102 million Nationally, 20,400,000 to 22,000,000 for Appalachia and 15,000,000 or more in New York State.

"The first estimate of the York Crop was 4,850,000 bushels, this compared to a crop of $2,682,0(00$ in $1953,5,353,000$ in 1952 and a ten year average of $5,198,000$ bushels.

"You all know what happened. The National crops turned out to be 10:3,773,000 bushels, Appalachia 2,3,225,000 bushels, and New York State $15,485,000$ and the York Imperial Crop ran to approximately $6,000,000$ bushels. This was less than $2 \%$ more than was estimated Nationally, approximated $6 \%$ more than was figured for Appalachia and about $7 \%$ more for New York.

"Another reason we couldn't hold our opening prices was that the New York State processors started buying apples at considerably less than our prices. Some of them were paying less for $23 / 4$ " Up apples than we were for $21 / 2 "$ Up. We were forced to adjust our prices to endeavor to meet the situation.

"About two weeks later one of the more recent packers of Apple Sance in this area reduced their price for fruit about $10 \%$ under that being paid by the major processors. This cut, though, was not followed by the major preeessors at that time.

"From the very beginning of the season there were certain processors in New York State and this area who were underselling by $3 \%$ to $5 \%$. During the first part of the season, the major packers of Apple Sauce held their prices firm and relused to meet these reduced prices.

"However, when one of the newer packers of Apple Sauce in this area used their $10 \%$ price reduction in fruit to still further reduce the price of the finished product and this further reduction was met by a larger processor, who was processing his own lruit, it was necessary for the major packers to adjust the price of their finished prodnct downward to meet competition, or else they would lose customers of many years standing. I am quite certain that if any grower in this room faced the loss of a customer he had had for many years he would do the same thing to retain the customer's business.

"The smant buyers began to take advantage of this, withholding business fro:m the major packers with established brands and hegan to play these weak 
scllers in New York against those in this area. Some of these shrewd buyers cut off buying from this area, leading the processors down here to believe they were buying cheaper in New York State. Some of the cut-price sellers in this area, who were either buying apples at less than the major processors. or were processing their own fruit, reduced their prices even further under this pressure. Thus, they began a see-saw price reduction battle with the (opj)rortunist packers in New York State.

"While the consumer was apparently willing to buy Apple Sauce on the basis of $\$ 1.85$ or $\$ 1.70$ per dozen for No. $30: 3$ cains, the most poupular comsumer size, the chains were apparently unwilling to buy apple satuce (m this basis for far that some competing chain might buy cheaper and undersell them. This price cutting, which was started by weak sellers, not only justified the buycers in this stand, but also made them afraid and hesitant to promote Apple Saluce. Promotions have to be planned a week or two wecke ahead. The people who merchandise and promote Apple Sance would naturally be reluctant to feature and plan a promotion on sauce when they were afraid that a competitor might have a cheaper price than they would lave in a week or two weeks. W'e, therefore, did not get the same promotion of Apple Sance this fall that we did a year ago, with the result that our movement of sauce was not als great this fall as it wals al year ago.

"While the price of goud fresh fruit held up good all during the harvest season, the price of poorer fruit did not hold up as well on the fresh market. By the time the winter varieties began to be harvested, the movement of the fruit into the fresh market bogged down and pressure began to be put upon the processing outlet to handle more fruit.

"This made a record-breaking pack of Apple. Sance a very geod prospect and was another facter contributing to the general chactic (e)ndition of the sance market. This has turned out to be an actuality. It is now "stimated that the pack of sauce will go over $1.51 / 4$ million cases.

"After the price-war had gene" on for several weeks and it becalne vers crident that the pack of apple samee would reach a record size, the major packers in this area, who had been holding firm on both the price of raw fruit and the processed product, were compelled to reduce the price of frut drastically in an endearor to alverage ont their costs so als to meret these cuit prices on apple satuce.

"The price of apple sance thus tumbled from an operuing of $\$ 1 . \overline{0}()$ to it low of $\$ 1.25$ for the most popular size.

"While the large overpack of sance and the low priess this year atre lumting at the monent, and maly have a depressing eflect mest vear, the lone ratere result will be good.

"The larege supply and low priecs in the pist hatve alwatls increased (musumption and it will do it again.

"The problem is going to be to keep the new users supplied in the

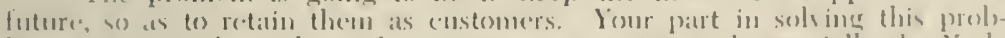

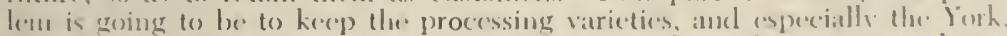

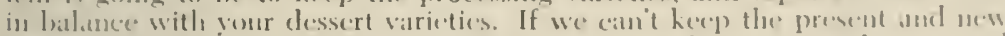

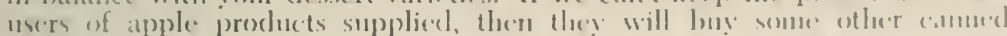
fruit, and we will lese it enstemur."

Ilunt's analysis of the situation tends to show the relationshipe of some of the forces insolving processors. First, it empliasizes the fact that growers comsider fresh and processor horers as highly smbstitutable.

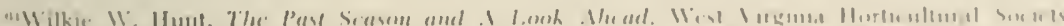

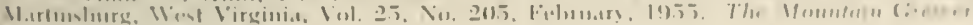


Second, it emphasizes the high degree that one processor may be substitutable for another, both as a buyer of apples and seller of apple products. The inference is that a relatively small processor precipitated the drop in price of both apples and sauce. The substitutability of apple products also is high between the Appalachian Area and New York. Appalachian Area processors are concemed about the price of apples paid by processors in New York, not because it affects the supply available to them but because of its effect on the price which New York processors might attempt to obtain for their apple products. The inference is that if New York processors can obtain apples "cheaply," they might be inclined to put up a large pack and sell at a lower price than if they had paid more for their apples. By so doing they would apply pressure on Appalachian Area processors to sell at a lower price.

\section{Some Characteristics of Knouse}

Some of Knouse's characteristics have already been discussed. However, to give a complete picture of the nature of the cooperative, more information is needed. Knouse has about 400 members. These members are mostly the leading apple producers in the Appalachian Area. This appears to be significant. In some cases cooperatives seem to be composed of marginal producers who look to their cooperative for help in solving their problems. In such cases the cooperative often fails because it is asked to do the improbable. Such is not the case with Knouse. Most of its members also sell apples to processors other than Knouse. Most of them also sell apples to the fresh outlet. One of the directors of Knouse stated to the author that the cooperative encourages its members to sell to other processors, particularly when it is felt that the other processors are paying prices higher than economic conditions justify, or when members have apples of a quality or size that Knouse does not particularly need-provided that other processors return as much as the cooperative. However, Knouse wants to be able to take the growers' apples if other outlets are not returning as much as the cooperative. Such an attitude as this on the part of the membership and management of a cooperative goes far toward putting into practice what was theoretically presented in Chapter II. The leading apple producers in the area are using the cooperative as a device for measuring the efficiency of other processors. Such a policy also puts pressure on the cooperative for efficient operation. The membership of the cooperative is attempting to support it by providing it with a large volume of apples. Table 8 gives Knonse's volume as a percentage of total volume in the Appalachian Area. 
Table S. Knouse's Volune As a Percentage of Total Volume IN the Appalachian Area, 1949-55.

\begin{tabular}{|c|c|c|c|}
\hline YEAR & $\begin{array}{c}\text { APPLES } \\
\text { ProCESSED }\end{array}$ & $\begin{array}{l}\text { SAITCE } \\
\text { PALKED }\end{array}$ & $\begin{array}{l}\text { Suices } \\
\text { Packed }\end{array}$ \\
\hline 1949 & 18.8 & 12.1 & 40.4 \\
\hline 19.50 & 20.3 & 1.5 .0 & 29.6 \\
\hline 1951 & 14.7 & 13.2 & 24.4 \\
\hline 19.52 & 9.9 & 9.3 & 20.4 \\
\hline 1953 & 14.9 & 14.3 & 22.9 \\
\hline 1.9 .54 & I 6.6 & 16.2 & 2.5 .5 \\
\hline 19.55 & $20.8 x$ & 22.8 & 22.6 \\
\hline
\end{tabular}

$\mathrm{x}=$ estimated.

Source: Knouse Fond Cooperative, Inc.

The nature of a firm's cost curves would determine the effect of size on total cost. This in turn would tell the importance of relative size on the ability of one firm to apply competitive pressure on another. With this in view an examination of processors' costs will be made.

\section{Nature of Processor Costs}

The nature of cost and of relative costs among firms has important impilcations on the behavior of the firms in a sub-group. If overhead cost is relatively small, and there is little advantage to large-scale firms, entry of new firms may be easier, and there is less tendency for prochuction to be concentrated in the hands of a few firms. If some firms are more efficient than others, the more efficient ones are in a position to bring strong pressure on the less efficient ones. Likewise the less efficient firms lack such power.

From the limited information available, the nature of cost and the relative cost among firms will be examined. The OPA made a cost study of some of the apple processors in the Appalachian Area."in Table 9 gives costs of packing applesance by three firms.

The total costs of packing a dozen \#30:3 cans of applesance in 1941 were 6.5 and 67 cents for Musselman and National respectively. It cost Shenandoah 32.8 per cent more than National, or $\$ 9$ cents to pack a dor.n. Yusselman and National buy approximately the same volume of apples. However, Musselman produces considerably more sauce than Nitional. Shenandoals is approximately one-fifth the size of either of the other two. Although Musselman and National had approximately the sime total cost for packing one dezen \#30:3 cans of sance, there wias some vilriation in individual cost items.

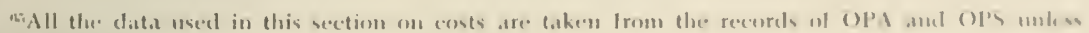
stluerwive ateited. 


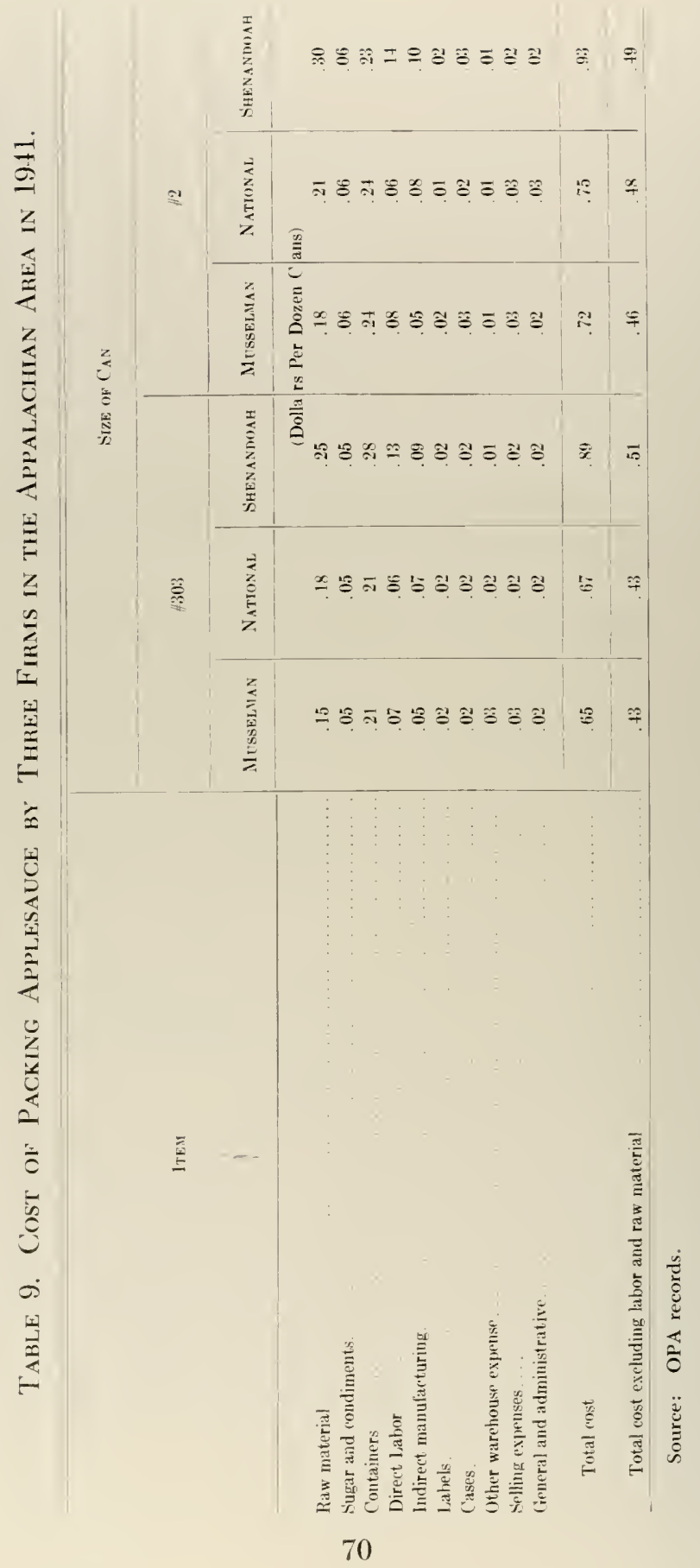


National paid more for apples but less for labor. This was also true for other size cans of sauce, as well as for apple slices. National consistently has maintained that it can pay a premimn for larger apples and offset the extra cost per pound by less labor costs in processing. This tends to verify their contention. Also, according to the Federal-State Grading Standards, there are about 15 different classifications for processing apples, depending on variety, size, and quality. Different prices are paid for the different classification. Since apples from several classificiations go into the production of a single product, it is possible for raw material costs to vary even though the same price is paid for cach classification. This is true because different firms use different proportions of the various classifications in producing any one product.

Shenandoah had a somewhat higher cost than either National or Musselman. The higher cost was explained largely by higher labor and raw material (apples) costs. It was previously pointed out that Shenandoah is an integrated operation, owned and operated by the apple producers who supply most of the apples processed. Since the same people were involved in all cases, Shenandoah has followed a policy of retuming net earnings to apple growers and employees, as well as dividends on stock. This practice may account for the higher cost of labor and apples. In comparing Shenandoals with the other two firms, in order to climinate the effect of such a policy, direct labor and raw material costs were taken from total cost. This gave a cost of 43,43 , and 51 cents per dozen for Musselman, National, and Shenandoalı respectively. Shenandoah paid 7 cents per dozen more for containers than did the other two. This particular case appears to be an exception in that in the same year they paid for \#2 cans 1 cent per dozen less than did the other two firms. In 1941 they paid the same for \#10 cans as the other firms. In 19.43 all three firms paid identical prices for \#30:3, \#2 and \#10 cans. the most popular size. If adjustment is made for the 7 cents extra paid by Shenandoall, and raw material and direct labor costs are excluded. Shenandoahis costs are 44 cents per dozen, compared with 43 for both Mlusselman and National.

Table 9 gives costs of packing \#2 eans of applesance for the samme firms. The results are (puite similar except that shemandoah pays I cent per dozen less for containers than Mhsschman or National. Again, edcheling labor and raw material costs, the costs for paching one dosen $\# 2$ cams of applesance were 46, 45, and 49 cents for Musselman, Natimal and Shemandoah respectively.

Table I0 gives the cost of packing apple slices for M/usselmam mul National. Again costs are similar for the two firms. In standard pach 
Table 10. Cost of Packing One Dozen \#10 Cans of Sliced Apples by Two Firis in the Appalachian Area, 1941.

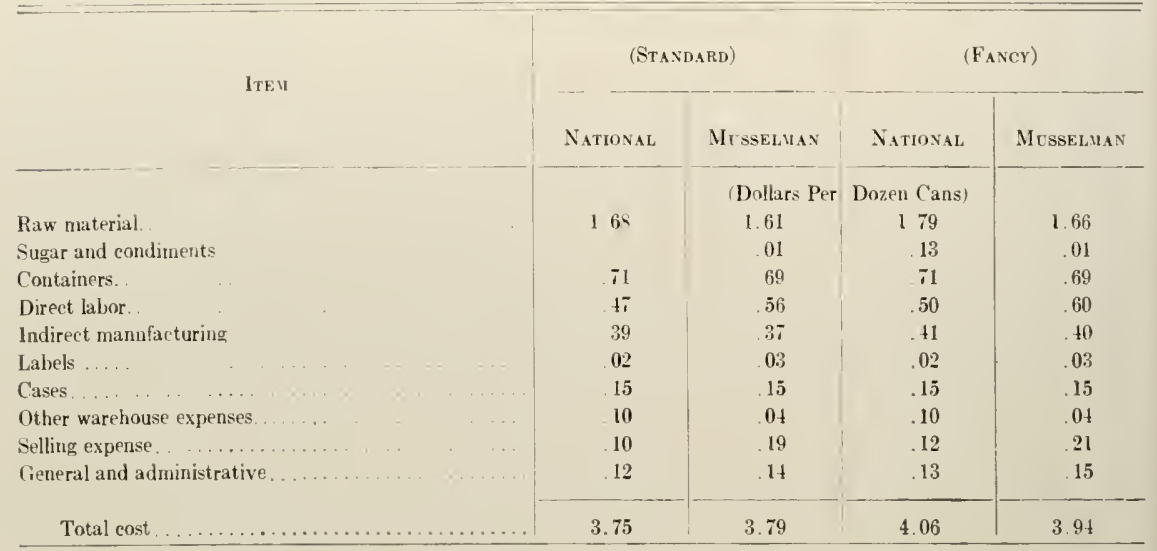

Source: OPA records.

there is a difference of only 4 cents per dozen, but in the case of the fancy pack there is a difference of 12 cents per dozen. However, in this instance National spent 12 cents per dozen cans on more sugar and condiments than did Musselman. However, when adjustments are made for differences in costs of sugar and condiments, adjusted costs are the same.

The OPS made a study of certain cost items for sauce and slices in New York and the Appalachian Area for the 1948 season. The Appalachian Area produces approximately one-half the nation's production of sauce and slices, and New York produces slightly less than one-third. (Tables 3 and 4 ). In the Appalachian Area six processors produce the bulk of the sauce and slices, and two produce about 50 per cent of the production in the area. In New York the situation is quite different.

In 1947 there were 55 firms in New York processing apples. However, 22 were handling over 77 per cent of all apples processed, and 18 of the 22 processed only apples. ${ }^{66}$ From 1946 to 1948 the two largest New York processors produced 13.3 per cent of the national production of applesauce and 16.3 per cent of national production was produced by other firms. Indications are that there were several rather small processors in New York.

Table 11 gives the cost of certain major variable cost items in the production of sauce and slices in the Appalachian Area and New York.

${ }^{15}$ Benuett A. Dominick, Jr., The Fruit and Vegetable Processing Industry in Net York State. 11 U. Agricultural Experiment Station, Ithaca, New York, A, E. 714, November. 1949. 
Table 11. Average Cost of Certain Itenis in Packing Applesalce and Slices in the Appalachian Area aNd New York, 1948.

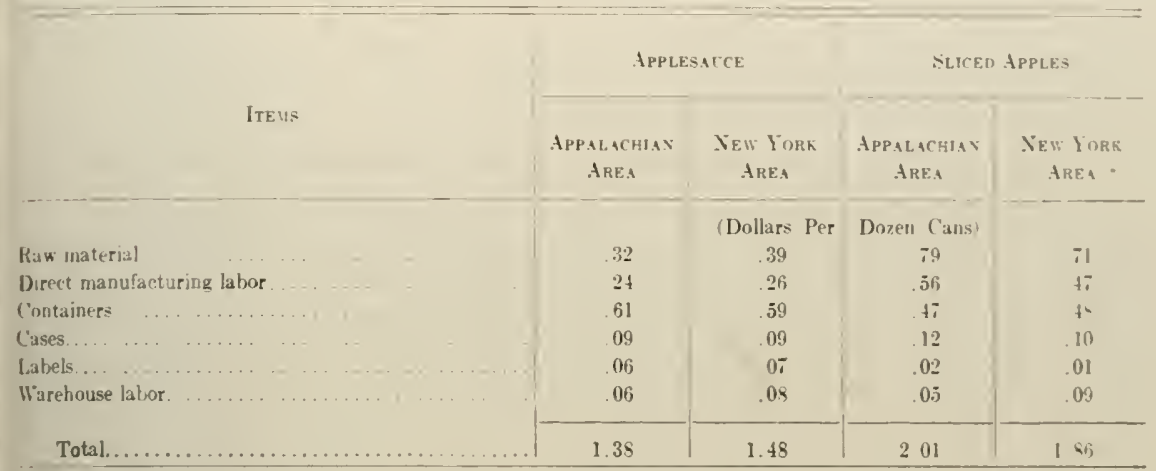

Sourct: OPS records.

In producing sauce New York has slightly higher costs than does the Appalachian Area and slightly lower costs in the production of slices. Tables 3 and 4 support the implication of these cost figures in that the Appalachian Area is gaining in sauce production relative to New York. and New York is gaining in the production of slices relative to the Appalachian Area.

The data are rather limited in many respects; however, they give clues as to the nature of costs. The information presented on cost is a suap shot of some given outputs for particular plants, and of the average outputs for several plants. Fixed costs represent only between 10 and 1.5 per cent of the total cost. Variable factors of production are available to all firms in the market sub-group at about the same price. The limited evidence available supports the thesis that costs are similar for different firms whose capacities vary considerably. This indicates that there are constant returns to scale of plant, and little if any economy to scale within the range studied.

In the short run, it is rather easy for a firm to expand its output. This may be done by operating more hours per day or for a longer season. While there will be a slight decline in overhead cost per unit of output. this will probably be offset by increased costs inciclental to the expansion. Overtime. storage of appless and loss of quality due to storage all temel to increase costs of operation as the firm expands its operations. From the clatal arailable it appears that, within the range of firm size sturlied. there are constant returns to scale, and that short-run costs comeren of at given firm have a rather wide trough to their U-shape. 
These generalizations relative to costs may be looked upon as hypotheses. Although the data gives support to them, there is need for further study. From what is known about the situation these hypotheses seem reasonable. Some of the reasons why costs may be expected to be different for different size firms are examined.

Selling costs immediately come to mind as being favorable to a large firm. However, apple processors do not attempt to promote brands by extensive advertising and their selling costs are low. Risk is another factor to consider. Often large processing firms draw their supplies of raw materials trom a wide area and do not run the risk of depending on a particular area. However, apple processors in the Appalachian Area all depend on the same suppliers for their apples. This makes this risk the same for all sizes of processors. Often it is believed that large firms are able to use better and larger equipment than small firms or to buy factors of production at lower prices. This does not seem to be the case among processors. Each of the small processors in the area handles a volume of about one million cases annually. Most of the machinery for processing apples is of such a size that the small firms have several units of each type. All use the same source of supply for containers and pay approximately the same price. Both the data available and what is known about the situation support the hypotheses set forth.

\section{Entry of New Firms}

Cost conditions as outlined in the previous section make the entry of new firms relatively easy. Since 1939 Bowman, Byrd, and Knouse have entered the sub-group. The entry of firms in the sub-group need not cause an increase in the cost of production for the group, if costs are constant over a wide range of output or if the demand for the products is expanding. Both situations appear reasonable in the market sub-group made up of the apple processors in the Appalachian Area.

\section{Summary}

It appears that the derived demand curve for apples and the supply of apples for the market sub-group comprising apple processors in the Appalachian Area are rather elastic.

The prices paid by processors for apples result from decisions of a few processors. These processors recognize their high degree of substitutability as buyers of apples and also recognize that they all must pay about the same or idential prices. However, they customarily use 
implicit price devices for minor price adjustments in an attempt to differentiate their offers.

One of the processing firms is a cooperative. It has introduced the use of patronage refunds. This has caused other firms to make bonus payments to their suppliers. This cooperative has the support of over 400 of the leading apple producers in the area.

There are indications that some of the processors take a somewhat broader view than short-run profit maximization. They consider the effect of their price on: (1) the long-run supply of apples, (2) the entry of new firms, and ( 3 ) the behavior of other firms. Such considerations tend, in the short-run, to cause a higher price for apples and a lower price for apple products.

Costs are rather uniform among processors whose outputs vary considerably. It also seems that costs for a particular firm should be rather constant over a considerable variation in output.

Entry in the market sub-group appears to be relatively easy. Three firms have entered successfully since 1939.

This gives considerable information relative to the policies and characteristics of the apple processors in the Appalachian Area. What does it tell relative to the price, output, and competitive pressure among processors in the area? The next chapter will attempt to answer this question. 



\section{Chapter VI}

\section{ANALYSIS OF COMPETITIVE BEHAVIOR AMONG APPLE PROCESSORS IN THE APPALACHIAN AREA}

T HE price-making units involving apple processors in the Appalachian Area has been delineated and the firms have been iclentified.

Some of the factors which affect the competitive behavior of firms also have been identified and the practices and characteristic of the firms relative to their competitive behavior have been described. However, up to this point a rigorous examination of the amount of competition among processors in the area has not been made. In an attempt to do this, the use of theory may be helpful. Consecunently: use will be made of certain theoretical concepts in analyzing the problem. Such an analysis is related closely to the problems which have oceupied the attention of writers since the field of imperfect competition analysis was developed by Chamberlin and Robinson. ii

In the analysis of this problem the market sub-(roup will be abstracted from the rest of the economy and it will be assumed that all other conditions are constant. That is, the assumed supply of apples and the demand for apple products will be considered as given for the subgroup under consideration. Under these circumstances the problems to be resolved are: how do the firms imvolved compete and at what price and output do they finally arrive?

\section{An Analysis of Factors Affecting Competition}

The extent to which excess profits exist meler conditions of imper fect competition is limited by the elasticity of the demand and supply curves facing the sub-group. The more elastic the curses the leas the opportmity for excess profits." It has been arerued thitt anpply and demand curves facing apple processers in the Appollachian treat are rather elastic. Just how dastic is not kuown. Howerer, the are not

ni( : hamburlin, (1). (il).

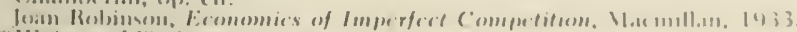

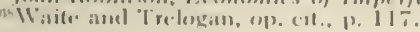


expected to be perfectly elastic. Therefore, there should be an opportunity for at least some excess profits.

Starting with the assumption that the sub-groups derived demand and supply for apples are elastic but not perfectly elastic. this chapter deals with the problems of how the firms in the sub-group evaluate the situation and how their decisions affect excess profits. The analysis is in terms of whether or not certain factors tend to apply competitive pressures in the sub-group. The effects of certain factors on the behavior of the sub-group are isolated. Finally, a summary of the situation conceming the extent of competitive pressure in the sub-group is made.

Throughout the analysis in this section the same assumed derived demand and supply relations used in Figure 2 are used. They are not proposed as being representative of the actual curves facing the group in the real world. However, they are used as a device to illustrate the effect of certain decisions of the firms involved upon the price and output of the sub-group.

As a point of departure a review of the case of duopsony, illustrated in Figure 2, Chapter II. is made. In this figure it was assumed that the two firms recognized their mutual dependence and price and output were the same as under monopsony. It has since been argued that if there are more than two firms the solution is the same as long as all of the firms recognize their mutual dependence, and as long as costs are the same as under monopsony. Althongh there are only a few (six) firms in the sub-group, there are indications that some firms follow policies which have an effect similar to that resulting from a failure to recognize mutual dependence. First, a further examination will be made of the case of the cooperative considered in Figure 2, page 20.

\section{DUOPSONY, ONE FIRM BEING A COOPERATIVE}

In Chapter II it was argued that if one of the duopsony firms is a cooperative, there is a tendency for the price of apples to move from the equilibrim price of $P_{: 2}$ (monopsony price) to $P_{::}$(competitive equilibrium price). This in turn changes the quantity purchased by the sub-group from $\mathrm{OB}$ to $\mathrm{OF}$. One of the factors responsible for bringing this change about is the payment of patronage refunds by the cooperative. It has been shown that with the coming of the cooperative, patronage refunds by Knouse and bonuses by other firms have become parts of the final settlement between apple sellers and processors. The introduction of patronage refunds and bonuses may be considered as the equivalent of failure to recognize mutual dependence. Chamberlin has this to say about the solution where mutual dependence is ignored: "It sellers 
may be helpful in answering this question. The same derived demand and supply relations used in Figure 2 are reproduced in Figure 10. To simplify the illustration it is assumed that firm $\mathrm{A}$, a monopsonist, is at first the only firm in the sub-group.

It may be recalled that as a monopsonist, $\mathrm{A}$ is faced with the same demand and supply of apples as is the sub-group. A's marginal cost and marginal revenue are equal at $\mathrm{G}$ and output $\mathrm{OB}$. With quantity $\mathrm{OB}$, A must pay price $P_{2}$. After firm $B$ enters (which does one-fourth of the total business in the sub-group), A's relevant marginal cost and marginal revenue are equal at $\mathrm{H}$ and output $\mathrm{OK}$. To obtain quantity $\mathrm{OK}$, A must pay price $P_{2}$, the same as when $A$ was a monopsonist. Firm $B$ also pays $\mathrm{P}_{2}$ and takes quantity $\mathrm{KB}$, as this is also $\mathrm{B}$ 's most profitable price and output as long as B considers its demand and supply to be one-fourth of the sub-group.

Firms $A$ and $B$ together take quantity $O B$ and pay $\mathrm{P}_{2}$. This is the same price and output solution as under monopsony. A's volume has been recluced from $\mathrm{OB}$ to $\mathrm{OK}$, or an amount equal to $\mathrm{KB}$, the purchases of $\mathrm{B}$. A's excess profit has been reduced, but the excess profit for the sub-group remains the same. Therefore, the entry of $B$ has had no effect on the price of apples, on the price of apple products, or on total excess profits for the sub-group. However, firm B has applied competitive pressure to firm A by shifting As supply eurve upward and to the left and shifting

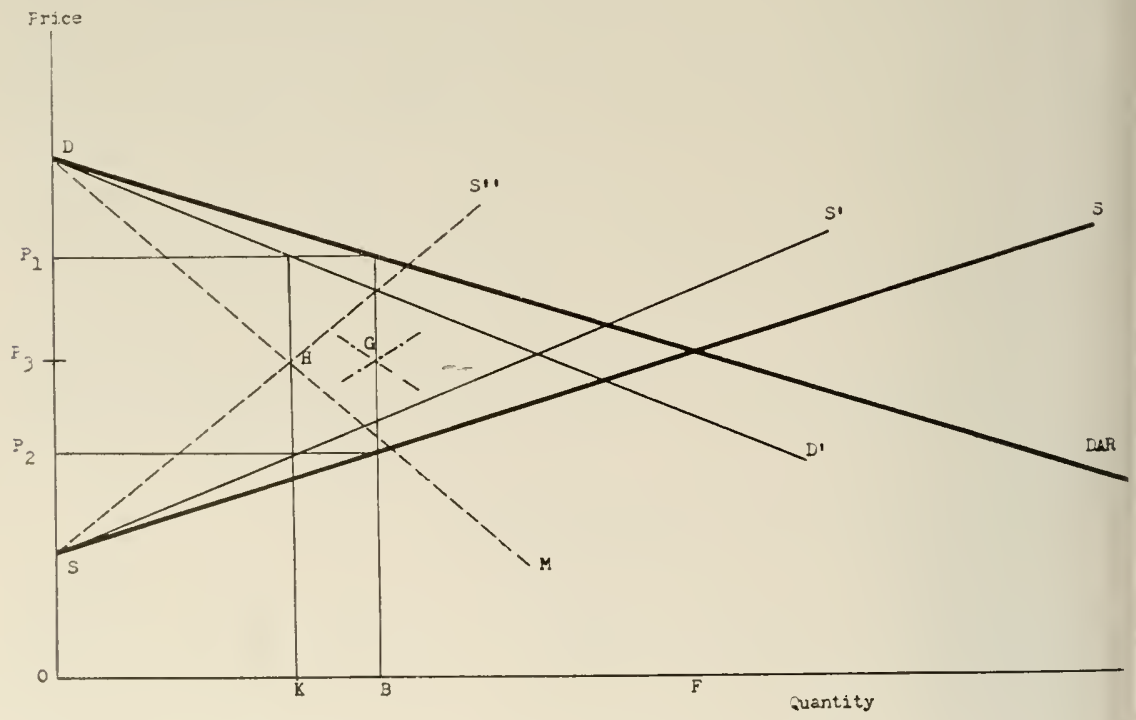

FIGURE 10. Hypothetical market sub-group-involving entry. 
A's derived demand curve downward and to the left. This in turn has reduced A's profit.

Under what conditions could entry lead to a more competitive price? Chamberlin has this to say on the matter: “. . . the break towards purely competitive levels comes when the number of sellers is so large that each is led to neglect his influence upon the price." "in

He also has this to say:

"As their numbers increase, it is impossible to say at just what point this consideration ceases to be a factor. If there were 100 sellers, a cut by any one which doubled his sales would, if his gains were taken equally from each of his competitors, reduce the sales of each of them by only 1 - 99, and this might be so small as not to force them, becanese of the cut, to do anything which they woukl not do without it. At whatever point this becomes true, the barrier to the downward movement of price from the point which will maximize the joint profits of all is removed. No one seller will look upon himself as causing the dislodgment, since he secures his gains with comparatively little disturbance to any of his rivals. Under these circumstances there is no reason for him to withlold a shading of his price which is to his advantage, and which has no repercussions. Nor is there any reason for the others not to do likewise, and the price becomes the purely competitive one."

With only six processors doing the bulk of the volume in the Appillachian Area, at first it seems mulikely that they would ignore their mutual dependence. However, a closer examination shows that there is considerable variation in the size of the processors. For example, suppose that Bowman, who does about 5 per cent of the business in the area, is considering expanding his output by 20 per cent and fecels that he has to improve his offer slightly to attract additional fruit. IIs might freel that he is doing so small a part of the total husiness that other processors would ignore such a move. If Bowman should improve his offer enough to increase his volume 20 per cent what would be the final result?

He could have been correct in his araluation of the sitnation. In which case other processors would iguore his move and he would find that his supply of apples would be highly elastic. In which case he might want to expand more than 20 per cent. Howerer, as long as the other processors ignored his unove, there would be little change cexept for his slightly improved offer for apples and his expanded ontput. On the other hatud, Shenandoah might follow a similar policy on the same assumption als Bowman. Other firms also might follow, in which case the final price for apples could be higher and output larger. The exact solution is indeterminate in that it depends upon the decesions of the vallous firms involved. For example, Musselman or Nittional might decide to set the price half-way between $P_{: 2}$ (monopsony price) and $P_{: 3}$ (competitice price) and

"winid, P. 18.

"Ibid, 1. 19. 
price could remain there the rest of the season. Hunt indicated that one of the small and newer packers started what he called a "price-war" which bought the price of sauce from $\$ 1.85$ per dozen to $\$ 1.25$ and the price of apples for processing from $\$ 5.00$ to $\$ 2.50$ per cwt. ${ }^{22}$ However, it should be kept in mind that in 1954 conditions seemed to warrant a price adjustment, and that the larger processors may have been glad to be able to place the responsibility for such adjustments on someone else.

Edwards has the following to say about ease of entry on competitive behavior:

"So long as entry is easy, the potential competition of new technology, new business methods, and new marketing policies tempers the behavior of the concerns already present. The effects of this potential competition are to reduce the likelihood of collusive agreement, to moderate the restrictions in agreements actually made, to lessen the restrictive effect of concentrated control over production or purchases, and to diminish the advantage which the most powerful enterprise can obtain through coercion.

"In addition to thus reducing the possibilities for avoiding competition and mitigating the restrictions in anticompetitive policies, easy entry is a safeguard against routinization of industrial activities. When established competitors in a market drift into a policy of live and let live as to prices, quality, marketing methods, or the adoption of new productive techniques, invasion of the market from outside is likely to shake them from their lethargy." "ז3

There are indications that ease of entry has some effect on the behavior of processors in the Appalachian Area, as was pointed out by Hunt when he implied that "newer packers" were upsetting the situation, and that his firm was paying a "high price" to discourage their activities. ${ }^{\text {" }}$

\section{HOW LARGE FIRMS MAY COMBAT COMPETITION}

Hunt gave as a reason for paying a high price for apples in 1954 the fact that he wanted to discourage other processors who "expand their pack far beyond their normal sales when they can buy fruit very cheaply." Ti. This would imply that there are processors who ignore their mutual dependence and take more than their "share" of the supply when prices are low, and less than their share when prices are high.

How would such action by a firm affect the price and output? An illustration will show the effect. Again using the same supply and derived demand for apples in Figure 11, assume that there are two firms. One, $\mathrm{A}$, behaving as Hunt outlined, and the other B, behaving as a price leader and allowing $A$ to take all it wants at all prices. Let DD' represent the demand of firm A for apples. To arrive at B's supply of apples DD should

\footnotetext{
7\%Hunt, op. cit., pp. 29 and 30.

Corwin D. Edwards, Maintaining Competition Requisites of a Govermmental Policy, 1st ed., McGraw-Hill, 1949 , p. 186

is Hunt, op. cit., pp. 27 and 29.
Thibid, p. 26 .
} 


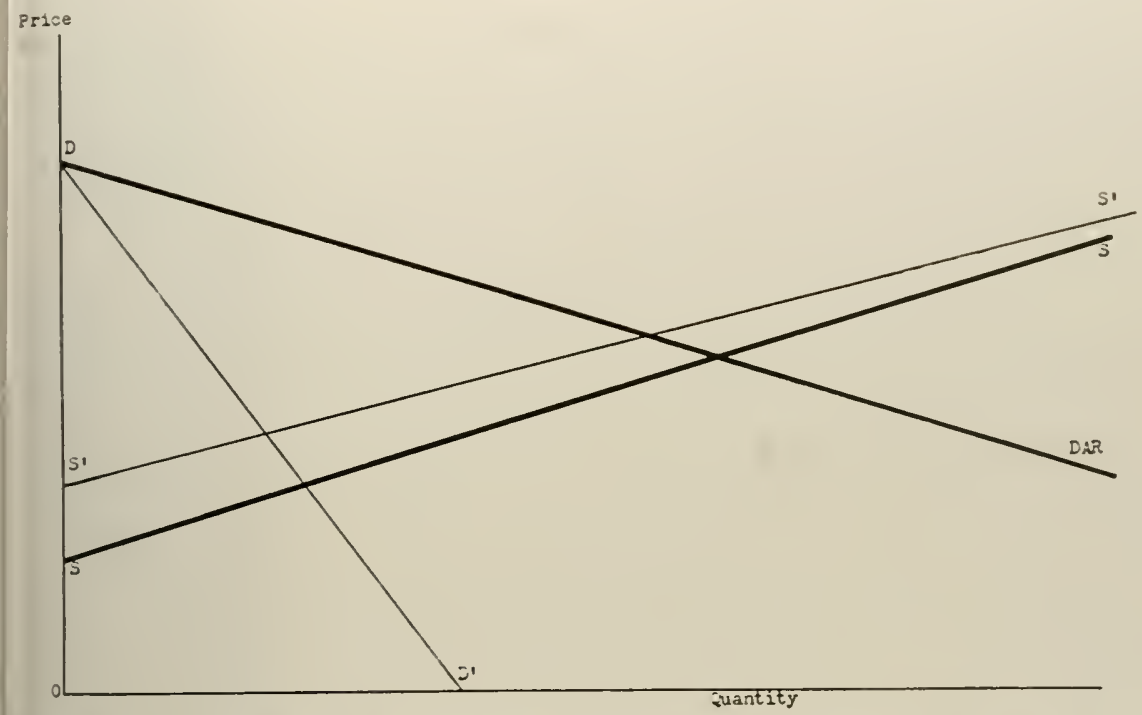

FIGURE 11. Hypothetical market sub-group-involving a competitive firm.

be substracted horizontally from SS. This gives S'S' as the supply of apples available to firm B. S'S' is more elastic than SS. Therefore the price and output will be above the monopsony price and output. Hence, a firm or group of firms behaving in this manner applies competitive pressure to the remaining firms and increases both the price and output. If the remaining firms, to combat such a situation, arbitrarily set a price higher than the monopsony price, by definition. competitive pressure has been applied. Such a price policy would increase the output both of the sub-gronp, and of the price leader and also would decrease the output of the small competitive firms. It would tend to discomage entry. Therefore, one way to discourage the entry of new firms is for existing firms to narrow their profit margin. Machlup has the following to say about such a policy:

$\because$. evisting firms will want to $b$ cautious and avoid showing profits that incite the eney and appetite of others. If high short-run profits are seen as a prosble danger to the stability of a situation that permits alu making of secure long-run profits at at more modest rate, most businessulen will forcege the former to safeguard the latter. In this semse potential neweomers competition moloub:edly exerts a restraining influence on price making and profit taking loy oligopolistic sellers." "a

It appears that this is what Innt was attempting to do when he paid al relatively high price for apples.

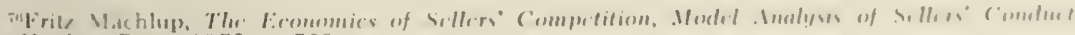
Johus 11 uph m, Press, 1952. 1). 5:39. 


\section{ENTRY OF AN INTEGRATED GROWER-PROCESSOR}

The entry of Byrd into the processing sub-group would have an effect similar to that of any other processor entering the sub-group. That is it would reduce the supply of apples available to the existing firms, reduce their profits, and have no effect on price if all firms continued to recognize their mutual dependence.

What effect would it have on the proportion of Byrd's crop which would be processed? If excess profits were being made by processors when Byrd switched from selling apples to other processors to processing them himself, his orchard returns from processor apples would be increased. This in turn would cause him to process a high proportion of his apples. Therefore, he would process a higher proportion of his crop than is processed by the area as a whole. This is not the case. Byrd is processing about the same proportion of his crop as other growers in the area. ${ }^{i \pi}$

\section{Summary}

In a market sub-group with a few firms, two of which do one-half the volume of the group and recognize their circular relationship, the firms could have more profits and less output than under conditions of perfect competition, assuming that costs are the same under both perfect and imperfect competition. However, there appear to be certain forces operating among processors which tend to offset the tendency toward restricting output and high profits. The evidence tends to support and confirm the thesis that the derived demand for apples and the supply of apples facing the sub-group are rather elastic. There are also indications that the relevant demand and supply relations for individual firms are more elastic than for the sub-group. The more elastic the demand and supply confronting a firm, the less the opportunity for monopoly profits.

Knouse, a cooperative, applies competitive pressure on other firms in the sub-group. When it entered in 1949, it reduced the demand and supply for the existing firms. Through the payment of patronage refunds, it, in effect, ignored mutual dependence and as a result forced other firms to pay bonuses. Patronage refunds and bonuses are considered by growers as a part of their net returns for apples. These practices increase processor price relative to fresh price and cause the growers to reduce sales to the fresh outlet and increase them to processors. The net effect of patromge refunds and bonuses is to increase the price of apples

${ }^{77}$ New York Times, November 6, 1955. 
for processing. This in tum means larger output by processors. Shenandoah operates similarly to a cooperative. The operations of Byrd also are similar to those of a cooperative. Knouse, Shenandoah and Byrd do between one-fourth and one-third of the volume in the area.

Entry of new firms appears to be relatively free. Three firms have successfully entered the sub-group-Bowman in 1939. Byrd in 1948, and Knouse in 1949. There are indications that National and Musselman pay a price for apples which is higher than that which would maximize their profits in the short run. Their long-run security seems to be the reason for such a policy and it is related to the following factors: (1) discouraging the entry of new firms, (2) discouraging the expansion of existing firms. and ( 3 ) encouraging apple growers to expand their output. particularly certain desirable varieties for processing.

Finally, processors, both large and small, ignore their mutual dependence to some extent and compete through the use of implicit price devices. These devices increase the growers' net returns. they increase his sales to the processor outlet, and they soon become general practices of all, once they are introduced by a particular firm.

When all factors are considered, competitive pressure is strong and excess profits tend to be small if present at all. However, in conclusion it should be recognized that each processor does not have perfect knowledge of demand and of his own costs, and that resources are not perfectly mobile. Consequently, he may not be able at once to hit upon his best price and output. Therefore, as under pure competition, prices fluctuate in a penumbra. ${ }^{79}$ However, it seems that the penumbra is more in the area of the purely competitive price than in that of the monopsony price. 
$\ldots$ 


\title{
Chapter VII
}

\section{IMPLICATIONS AND CONCLUSIONS}

\begin{abstract}
UMMARIES of most chapters have been made throughout the text. The purpose of this chapter is to draw this material together, to give an over-all picture of the study and of the conclusions reached.
\end{abstract}

The market sub-group is the unit in which price is established, as defined in this study. It includes all the firms which sell (or buy) substitutable products (relatively homogeneous) and have similar structural patterns. That is, the firms are confronted by similar problems and are in relatively close competitive relationships. It is within this group that price is established.

Using the market sub-group as the basic unit of inquiry, it was found that the following groups were involved in the apple purchasing activities of processors in the Appalachian Area: (1) all apple growers in the United States are in the same market sub-group. (2) all fresh buyers in the United States are in the same market sub-group, and (3) all processor buyers in the Appalachian Area make up a third market sub-group.

Price is established by a group of buyers and a group of sellers. It was argued that the structure of the market sub-group influences price behavior. It was further argued that; (1) number of firms. (2) substituability of the product, (3) the presence of a cooperative, and (4) the ease with which a firm may enter the sub-group are all structural factors which influence price behavior. Under conditions of pure competition the individual seller (or buyer) has no measurable effect on price. (Consecpuently, he is a price taker. He may determine how much he will produce, but he camot determine the price at which he sells (on lougs). However, under conditions of imperfect competition the indiviclual seller (or buyer) may be able to affect price as well as output. W'ithin this framework this study is concerned with how certain structural factors influence the behavior of the firm in determming price and ontput.

The pure competition model describes best the behas ion of apple sellers and fresh apple buyers. There are so mamy sedlers and buycrs in the sub-group that no one buyer or seller alppears to have any measurable effect on price, and has no incentive to attempt to follow an independent pricing policy. This is not the casse amonge apple processome in the Appalachian Area. 
Only a few processors comprise the buying side of their market subgroup. Although processors depend only on apple growers in the area for their supply, the pure competition model describes best the behavior of the apple grower-sellers in their relationship with processors. There are approximately 2,500 apple growers in the area. They produce about one-fifth of the national supply.

These growers not only consider any one fresh buyer as highly substitutable for any other, and any one processor-buyer as highly substitutable for any other, but they also consider fresh and processor buyers as highly substitutable.

Therefore, even though fresh and processor buyers are not considered as being in the same market sub-group, they are related closely and depend on the same area growers for their supply of apples. Since processors depend on growers in the area for their apples, and since the fresh price is established by the nation's growers and fresh buyers, processor price has little effect on fresh price. Therefore, for all practical purposes, processors in the Appalachian Area may consider fresh price as given. The quantity of apples available to processors is determined mainly by the relationship of processor price to fresh prices, Figure 9. Therefore, processors in the Appalachian Area must consider the price of a competing group of buyers (fresh price) as given and largely outside their influence. Consequently, this largely determines the price which processors must pay for any given quantity of apples, and it defines the supply curve of apples which faces processors. Under these conditions the supply curve woukl be elastic.

Applesance and slices are the principal apple products produced in the Appalachian Area. About one-half of the national supply is produced in this area. U. S. Grades and Standards are used widely as a basis for determining quality of apple products. Much of the sauce and slices is sold under the buyers' labels, and the promotion of processors' brands has never been used extensively. Therefore, under these conditions, processors' derived demand for apples in the Appalachian Area is elastic. The more elastic the supply and demand curves are, the less the opportunity for excess profits. Since apple processors are confronted with elastic supply curves and derived demand curves, how much competition is there among processors and at what price do they arrive?

Certain factors are present which indicate a lack of competition which would result in the monopsony price. Other factors indicate competitive pressure toward the purely competitive price. 
The following two conditions indicate a lack of competition:

1. Only a few buyers are in the sub-group, and two (Musselman and National) do about one-half of the volume of the group).

2. These few firms appear, at least partially, to recognize their mutual dependence. Either National or Musselman generally ansounces a price. and all other firms immediately announce similar if not identical prices. These two factors point to a lack of competition tending toward the monopsony price and output equilibrium.

The following four conditions point toward an elimination of excess profits by competitive pressure causing price to move to the purely competitive equilibrium solution:

1. In 1949. with the entrance of Knouse into the sub-gromp, there came the practices of patronage refunds and bonuses. Knouse, a cooperative, returns all receipts over cost of operating to its patrons on a patronage basis. The operating policies of Shenandoah and Byrd are similar to those of a cooperative and have a similar effect on the subgroup.

It was shown that five cents per cwt. is enough to cause growers to switch sales from one processor to another. Under conditions such as these the non-cooperative processors camnot afford to ignore patronage refunds on the part of a cooperative, even though such refunds are made after the crop has been marketed. Processors are concened with their apple supply and with the relative growth of other processors in the future.

Although patronage refunds and bonuses are made after the growers have made their decision as to how they will market their crops, refunds and bomuses tend to become factors which are considered by erowers in making marketing decisions because such paryments hatse been made in the past and are expected to be made in the future. That is, after patronage refunds and bonuses have become general practice, growers not only consider the announced price but also alssume that something more will finally be paicl, when they are decicling what part of their crop they will sell to processors. This may explain in part as to why processors have tended to be cleluged with apples in somer recent years.

2. Implicit price deals, a second factor responsible for (e)mpetitime pressure, are closely related to patronage refmels and bonmses. It was foumel that the anumomerel price may or may not represent the fimal settlenent between growere and processors. Inplicit price deals. which 
increase the growers net, are widely used. Such deals cause the processors to ignore, at least in part, their mutual dependence and to compete among themselves. Such practices increase the growers net returns and their sales to processors.

3. The ease of entry of new firms in a market sub-group influences the competitive behavior of the firms concerned. Since 1939, three firms have entered the sub-group. Both actual entry and potential entry appear to have a moderating effect on the decisions of firms to maximize their short-run profits. The evidence tends to indicate that Musselman and National have paid relatively high prices for apples in an attempt to combat both entry and the expansion of some of the smaller firms. Such policies indicate that processors consider long-run security as well as short-run profits when they establish price for a particular year.

4. The relative over-all costs among firms influence both the effectiveness of a cooperative and the ease of entry into a market subgroup. From the limited data available and from what is known about apple processing, there are indications that returns to scale are constant within the range of the capacity found among processors in the Appalachian Area. Also, costs for individual firms appear to be constant over their normal range of outputs. These hypotheses need further study. However, to the extent that they are correct, one firm is as efficient as any other firm. Such a situation maximizes the effectiveness of a cooperative and makes entry relatively easy.

Finally, it should be recognized that processors do not have perfect knowledge of demand and of their own costs. Also, resources are not perfectly mobile. Consequently, processors may not be able to establish immediately their best price and output. Therefore, as under perfect competition, price would tend to fluctuate around the equilibrium price. The important question is: IVill the equilibrium price for processors in the Appalachian Area tend to be in the direction of the monopsony price or of the purely competitive price?

From the analysis of the situation, it may be concluded that the opportunity for excess profits in the market sub-group has been reduced if not eliminated in recent years. The bulk of the evidence indicates that competitive pressure is strong among processors. It appears that there is little opportunity for excess profits over a period of time. The indications are that processor price and output are efficient in the allocation of resources. That is, comparable resources (apples) bring the same returns as in other uses (fresh outlet). 
Appendix I

SUPPLEMENTARY TABLES 


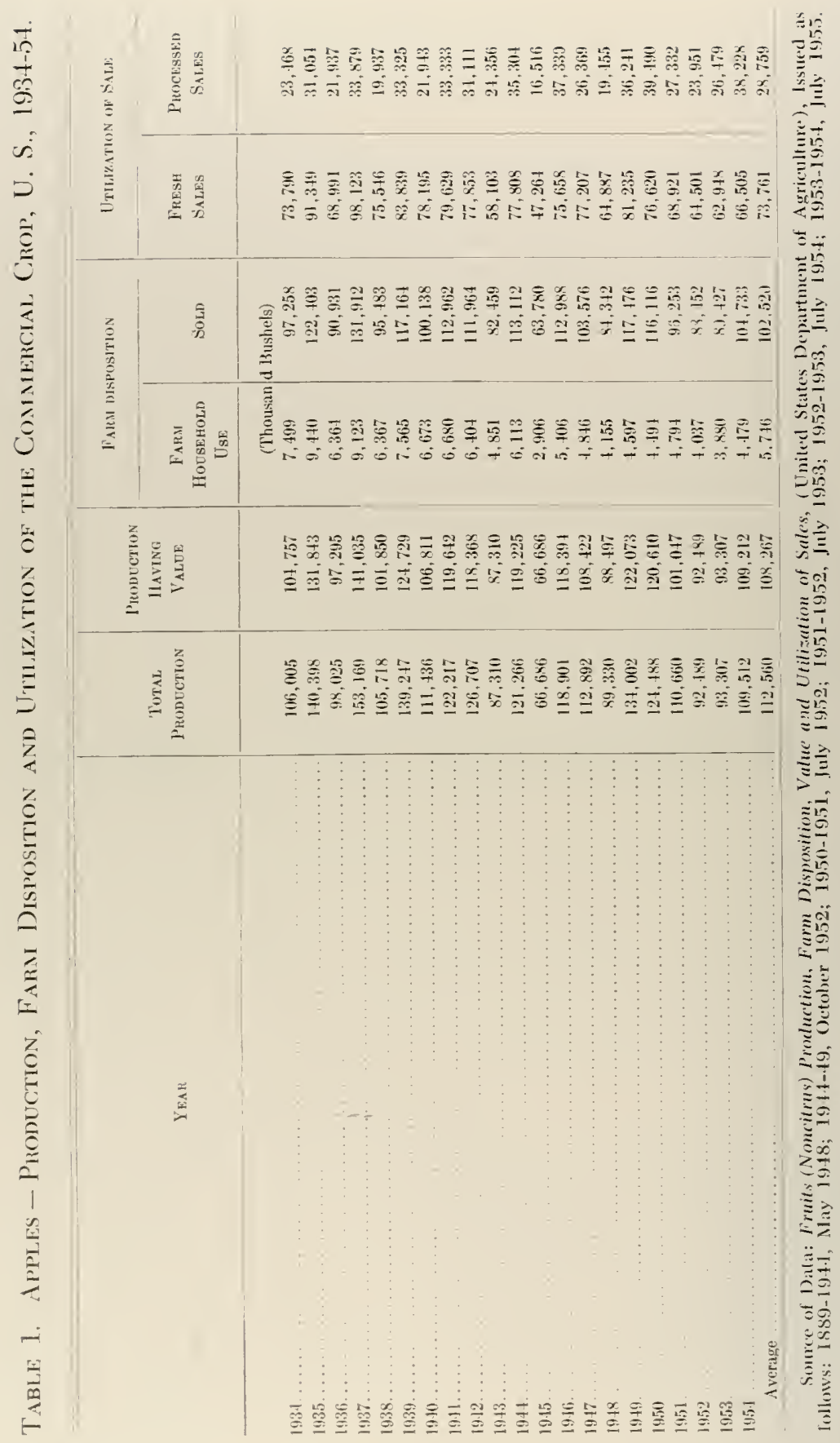




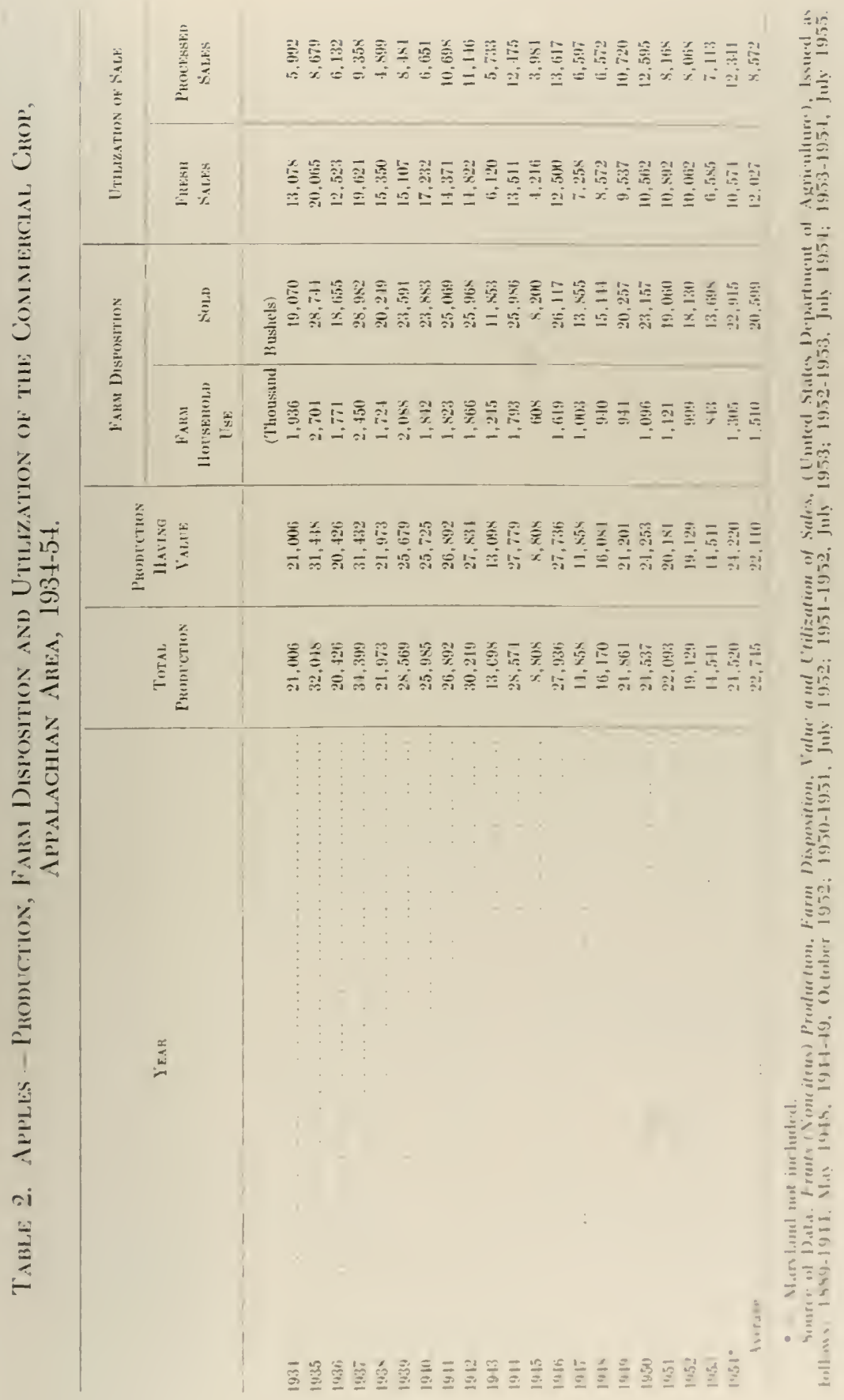


Table 3. Apples - Seasonal Average Prices Received by Grower by Type of Outlet, Appalachian Area, 19:34-54.

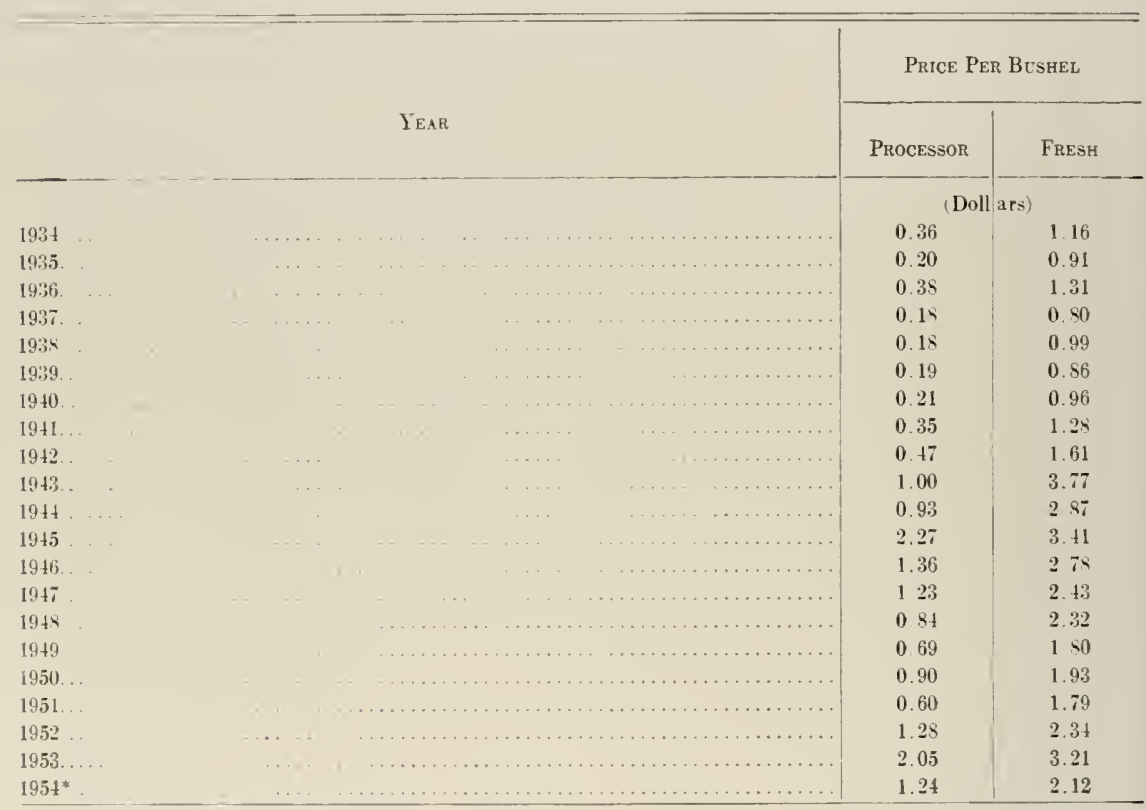

$\circ$ Maryland not included.

Source: Calculated from United States Department of Agriculture Crop Reporting Board Data. 

Appendix II

\section{SUPPLEMENTARY MATERIAL}




\section{Historical Background of Knouse Foods Cooperative, Inc.}

$\mathrm{T}$

HE following testimony of Mr. Knouse before the FTC hearings gives an interesting review of his background in connection with apple processing and the organization of the cooperative:

"In 192.5 I was a director in the First National Bank at Gettysburg. That bank inherited a canning factory, through a sheriff's sale, that was organized by a group of growers, by a rather swindler organization that had swept the country known as Northwestern Manufacturers Association.

"I was asked by the bank to go out and put this institution on its feet and it wasn't very long until I discovered that a National Bank could not operate a canning factory, and so the bank asked me to take it over and run it.

"The first attempt was to organize a partnership between myself and an uncle which lasted about thirty days and then I organized the Knouse Corporation and that continued until 1929.

"In 1929 I decided I owed New York banks too much money after the crash and I sold the majority interest in the business to the National Fruit Company and we operated as a subsidiary of National Fruit Products Company from 1929 to 1947 and the year 1947 we changed the name to Northern Division of the National Fruit Products Company and operated as a completely owned subsidiary.

"In 1949 National Fruit Product Company sold its Northern Division to a group of farmers, of which-I was one of them, and the Charter was taken out in the name of Knouse Foods Cooperative, Inc. . . . I am president of the cooperative which is owned by about 400 apple growers." 


\section{SELECTED BIBLIOGRAPHY}

Adans, Walter, ed., The Structure of American Industry, Some Case Studies, rev, ed., Macmillan Co., 1954.

Bakken, Henry H., and Mueller, Willard F., Oligopsony in the Wisconsin Tobacco Industry, Land Economics, Vol. XXVIII, No. 2, May, 19.52.

Boulding, Kenneth E., Economic Aralysis, rev. ed., Harper \& Bros., 1948.

Burns, Arthur Robert, The Decline of Competition, A Study of the Eecolution of American Industry, 1st ed., AcGraw-Hill Book Co., I9:36.

Chamberlin, Edward Ilastings, The Theory of Monopolistic Competition, A Reorientation of the Theory of Value, Harvard University Press, 1947.

Edwards, Corwin D., Maintaining Competition - Requisites of a Greermmentul Policy. lst ed., Mc.Graw-Hill Book Co., 1949.

Fellner, William, Competition Among the Few: Oligopoly and Similur Market Structures, Knopf Co., 1949.

Machlup, Fritz, The Economics of Sellers' Competition, Model Analysis of Sellers" Conduct, Johns lJopkins l'ress, 1952.

Manchester, Alden C., Price-Making and Price-Reporting in the Besston ligg .Market, IIarvard Studies in Marketing Farm Products, Number 7-H, Cannlridge, Mass., 19.54.

Marshall, Alfred, Principles of Econamics, An Introductory Volume, Sth id., Matcmillan Co., 1947 .

Vicholls, William H., A Theoretical Analysis of Imperfect Competition uilh Special Application to the Agriculural Industries, Iowa State College Press, 19.41.

Nicholls, Willian Il., Price Policies in the Cigarette Industry. A Study of "Concerted Action" and Its Sucial Comtrol, 1911-50, Vanderbilt University. P'ress, [(5).5].

Pippandreou, Andreass G. and Whecler, Jolun T., Competition and Its Reguletion. P'rentice-Hall, Inc., 1954.

Robinson, Joun, Economics of Imperfect Computition, Maconillan Co., 19:3:3.

Scitessky, Tibur, Welfare and Compctition, The Ecommics of a Fully limplonged E(t)uom!y, Richatrd 1). Irwiu, Inc., 1951.

Stigler, Ceorge J., The Theor! of Price, Macmillan Co., 1950.

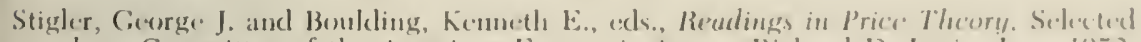

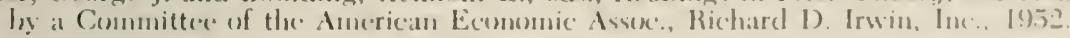

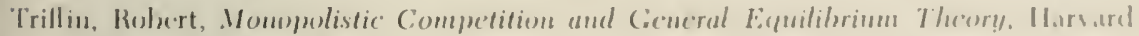
University P'ress, 19.19.

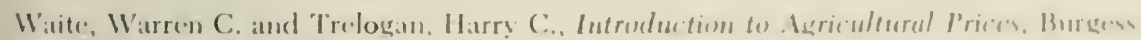
Publishing Co., I!)!!). 
